\title{
Effects of Wastewater Discharges on Endocrine and Reproductive Function of Western Mosquitofish (Gambusia spp.) and Implications for the Threatened Santa Ana Sucker (Catostomus santaanae)
}

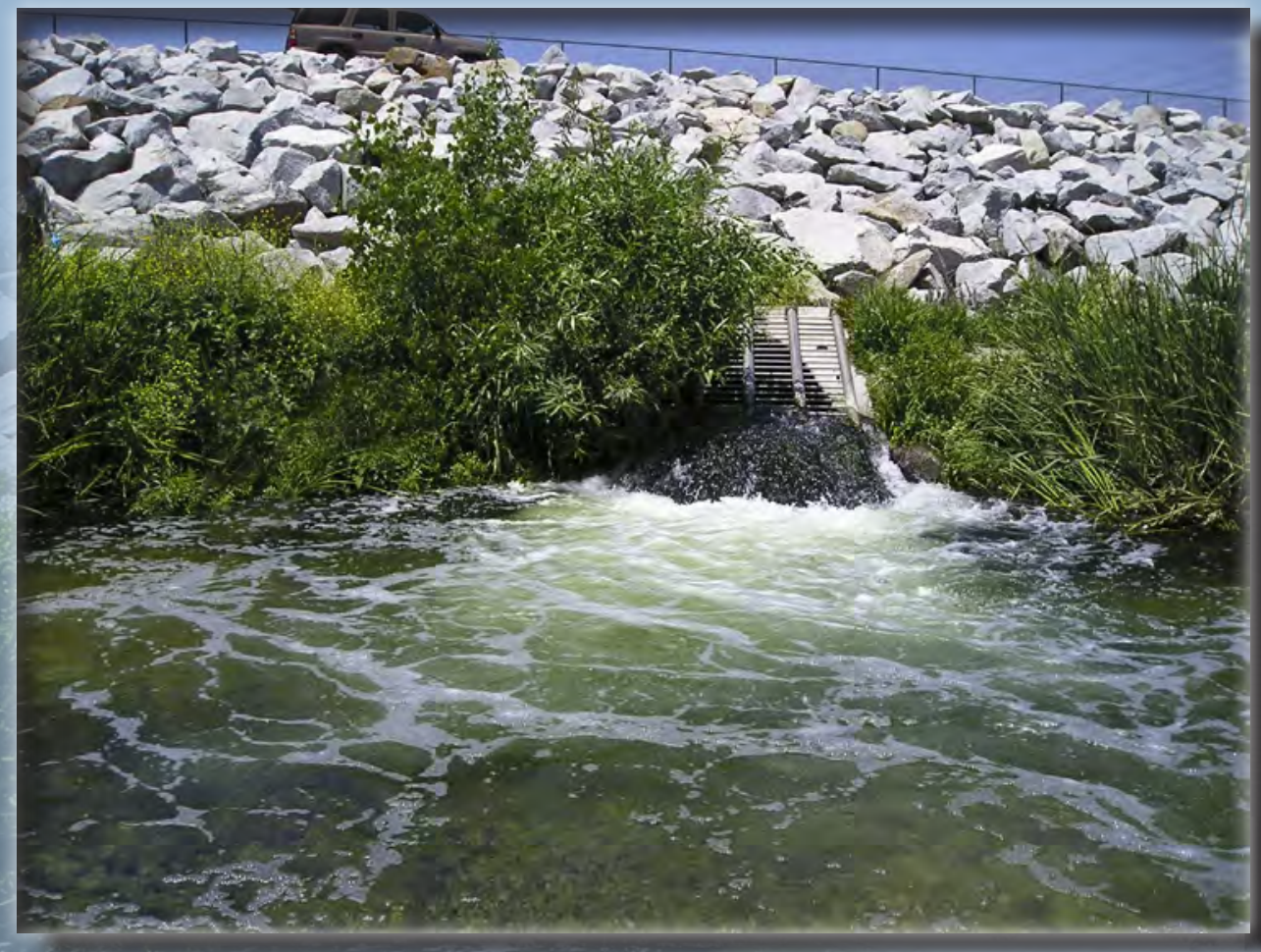

Open-File Report 2009-1097

Revised May 2009

U.S. Department of the Inteitor U.S. Geologicalsurvey 
Outside front cover photograph:

A tertiary wastewater effluent discharging into the Santa Ana River, Calif. Photo by Judy Gibson. 


\section{Effects of Wastewater Discharges on Endocrine and Reproductive Function of Western Mosquitofish (Gambusia spp.) and Implications for the Threatened Santa Ana Sucker (Catostomus santaanae)}

By Jill A. Jenkins, Steven L. Goodbred, Scott A. Sobiech, Heather M. Olivier,

Rassa 0. Draugelis-Dale, and David A. Alvarez

Open-File Report 2009-1097

Revised May 2009 


\title{
U.S. Department of the Interior \\ KEN SALAZAR, Secretary
}

\section{U.S. Geological Survey \\ Suzette M. Kimball, Acting Director}

\author{
U.S. Geological Survey, Reston, Virginia: 2009 \\ Revised: 2009
}

\author{
This and other USGS information products are available at http://store.usgs.gov/ \\ U.S. Geological Survey \\ Box 25286, Denver Federal Center \\ Denver, CO 80225 \\ To learn about the USGS and its information products visit http://www.usgs.gov/ \\ 1-888-ASK-USGS
}

Any use of trade, product, or firm names is for descriptive purposes only and does not imply endorsement by the U.S. Government.

Although this report is in the public domain, permission must be secured from the individual copyright owners to

reproduce any copyrighted materials contained within this report.

Suggested citation:

Jenkins, J.A., Goodbred, S.L., Sobiech, S.A., Olivier, H.M., Draugelis-Dale, R.O., and Alvarez, D.A., 2009, Effects of wastewater discharges on endocrine and reproductive function of western mosquitofish (Gambusia spp.) and implications for the threatened Santa Ana sucker (Catostomus santaanae): U.S. Geological Survey

Open-File Report 2009-1097., 46 p. (Revised May 2009) 


\section{Contents}

Abstract

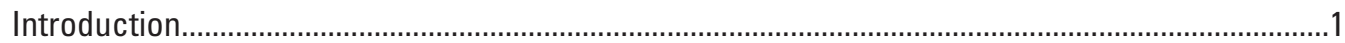

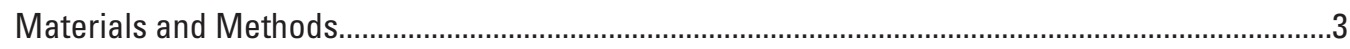

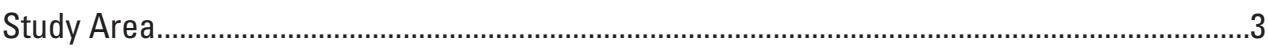

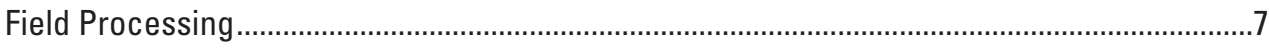

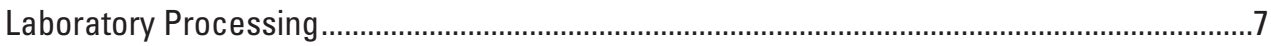

Contaminants Analysis ..................................................................................................

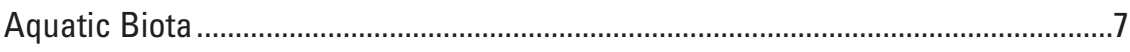

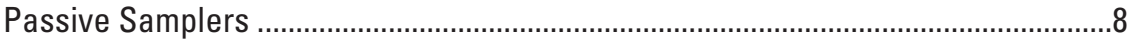

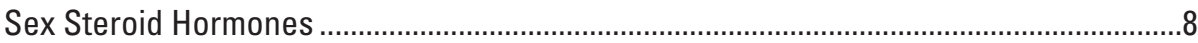

Secondary Sex Characteristics and Organosomatic Indices ........................................12

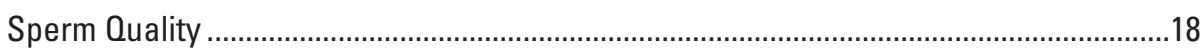

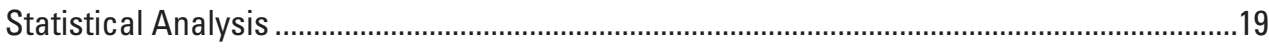

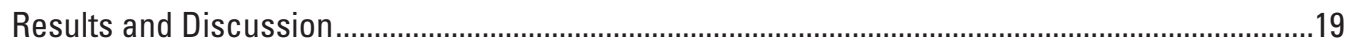

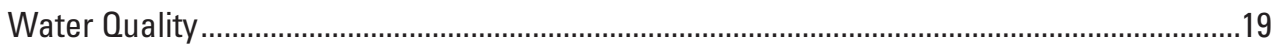

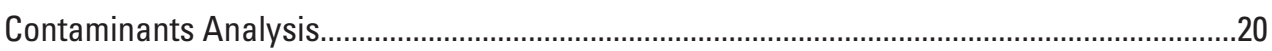

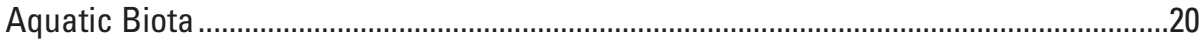

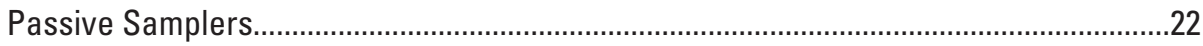

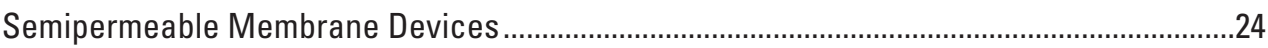

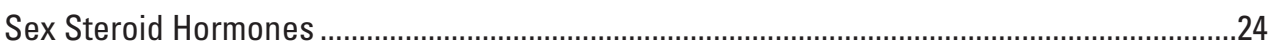

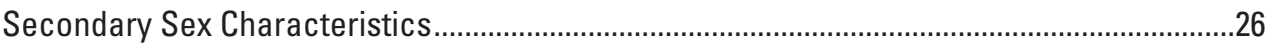

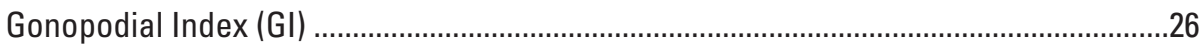

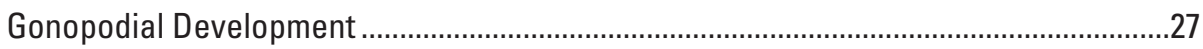

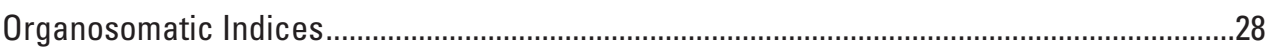

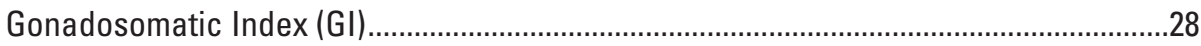

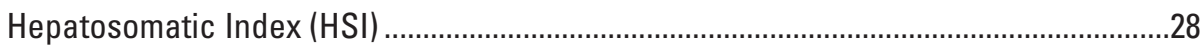

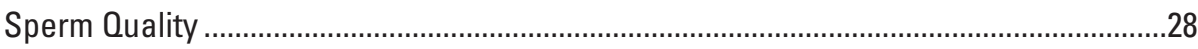

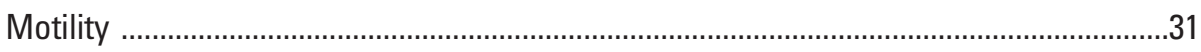

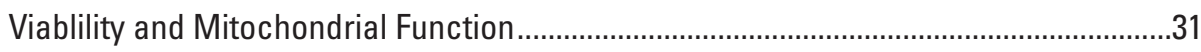

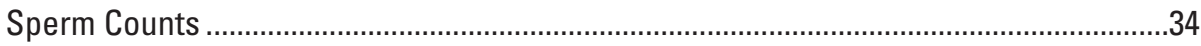

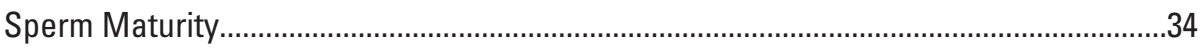

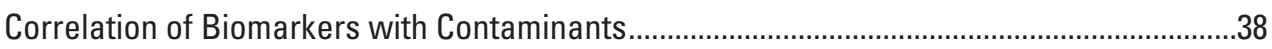

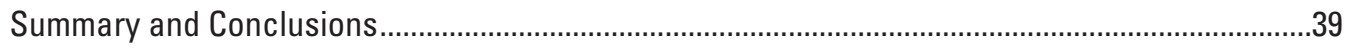

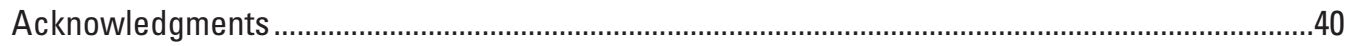

References

\section{Figures}

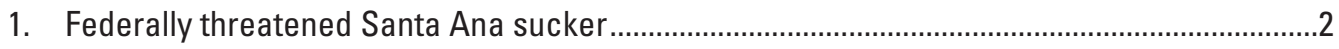

2. Sampling sites in the Santa Ana River watershed, Calif...........................................................

3. Plunge pool below a discharge site for tertiary treated wastewater effluent,

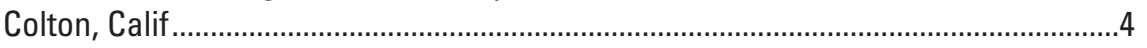

4. Rialto Drain below West Agua Mansa Road, Colton, Calif......................................................... 
5. Sediment control structure below Prado Dam, near Corona, Calif .5

6. Small channel of Santa Ana River within wetlands near Prado Dam, close to Corona, Calif.... .5

7. Sunnyslope Creek in the Rubidoux Nature Center, Riverside, Calif............................................6

8. Thousand Palms in the Coachella Valley Preserve, Thousand Palms, Calif ............................6

9. Percentages contaminant concentrations detected in fractions from extracts from polar organic chemical integrative samplers shown to have a response in an in vitro yeast estrogen screen assay .....

10. Percentages of contaminant concentrations that influence estrogenic function detected in semipermeable membrane devices from wastewater-related sites in the Santa Ana River, Calif..

11. Levels of $17 \beta$-estradiol , testosterone, and estradiol/testosterone ratios from western mosquitofish collected from the Santa Ana River, Calif., by site and year...

12. Gonopodial index values for samples of western mosquitofish collected from the Santa Ana River, Calif., in 2004

13. Gonopodial index values for samples of western mosquitofish collected from the Santa Ana River, Calif., in 2005

14. Typical, fully developed mature male gonopodium in western mosquitofish showing elongation and modification of anal fin with visible hooks

15. Underdeveloped male gonopodium from a western mosquitofish showing a small total length and elongation of anal fin without hook development

16. Hook score 1

17. Hook score 2

18. Hook score 3

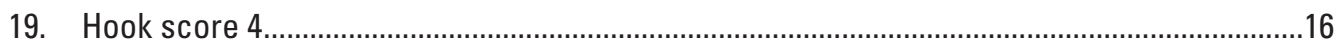

20. Anal fin ray segment 6 (S6) of rays 3 and 4 (R3 and R4) of western mosquitofish collected from the Santa Ana River, Calif..........................................16

21. Anal fin ray segment 6 (S6) of rays 3 and 4 (R3 and R4) of western mosquitofish collected from the Santa Ana River, Calif.

22. Measurement of width (microns) of segment 6 of ray 3 of a gonopodium from a male western mosquitofish

23. Measurement of width (microns) of segment 6 of ray 4 of a gonopodium from a male western mosquitofish

24. Gonadosomatic index values (GSI) (see standard error bars) from male western mosquitofish sampled from the Santa Ana River, Calif., in 2004 and 2005

25. Hepatosomatic index (HSI) values (see standard error bars) from male western mosquitofish sampled from the Santa Ana River, Calif., in 2004 and 2005

26. Visual assessments of progressively moving western mosquitofish spermatozoa from samples collected from the Santa Ana River, Calif., in 2004 and 2005

27. Percent viable sperm (see standard error bars) from western mosquitofish collected from the Santa Ana River, Calif., in 2004 and 2005.

28. Percent of spermatoza with functional mitochondrial membrane potential in western mosquitofish sampled from the Santa Ana River, Calif., in 2004 and 2005 
29. Sperm counts (see standard error bars) in western mosquitofish samples collected from the Santa Ana River, Calif., in 2004 and 2005...

30. Percentage of mature spermatozoa from western mosquitofish at Santa

Ana River and reference sites in California in 2004 and 2005

31. Correlation of testosterone in male western mosquitofish from Santa Ana

River sites in California in 2004, with concentrations of di

(2-ethylhexyl) phthalate from extracts obtained by using polar

organic chemical integrative samplers in 2005

\section{Tables}

1. Water quality parameters on sampling dates from field sites in the Santa

Ana River, Calif., June 2004 and 2005.

2. Organochlorine compounds in aquatic biota composites from the Santa

Ana River and a reference site, 2004.

3. Targeted wastewater contaminants detected in estrogenic fractions from polar organic chemical integrative sampler extracts from Santa Ana River and a reference site in 2005

4. Targeted wastewater-related contaminants detected in hormonally active fractions of sample extracts obtained from Santa Ana River sites, Calif., in 2005 by using semipermeable membrane devices

5. Concentrations of $17 \beta$-estradiol and testosterone and E2/T ratios from western mosquitofish collected from Santa Ana River sites, Calif

6. Number and percentage of categorized scores (where low is one to two and high is three to four) of gonopodial hooks and serrae from western mosquitofish in 2004 and 2005. 


\section{Conversion Factors}

Inch/Pound to SI

\begin{tabular}{|c|c|c|}
\hline Multiply & By & To obtain \\
\hline \multicolumn{3}{|c|}{ Length } \\
\hline inch (in.) & 2.54 & centimeter $(\mathrm{cm})$ \\
\hline inch (in.) & 25.4 & millimeter (mm) \\
\hline inch (in.) & 25,400 & micrometer $(\mu \mathrm{m})$ \\
\hline foot (ft) & 0.3048 & meter (m) \\
\hline mile (mi) & 1.609 & kilometer (km) \\
\hline mile, nautical (nmi) & 1.852 & kilometer (km) \\
\hline yard (yd) & 0.9144 & meter $(\mathrm{m})$ \\
\hline \multicolumn{3}{|c|}{ Area } \\
\hline acre & 0.4047 & hectare (ha) \\
\hline acre & 0.00405 & square kilometer $\left(\mathrm{km}^{2}\right)$ \\
\hline square mile $\left(\mathrm{mi}^{2}\right)$ & 2.59 & square kilometer $\left(\mathrm{km}^{2}\right)$ \\
\hline \multicolumn{3}{|c|}{ Volume } \\
\hline $\begin{array}{l}\text { barrel (bbl), (petroleum, } \\
1 \text { barrel=42 gal) }\end{array}$ & 0.159 & cubic meter $\left(\mathrm{m}^{3}\right)$ \\
\hline ounce, fluid (fl. oz) & 0.02957 & liter (L) \\
\hline pint (pt) & 0.4732 & liter (L) \\
\hline quart (qt) & 0.9464 & liter $(\mathrm{L})$ \\
\hline gallon (gal) & 3.785 & liter $(\mathrm{L})$ \\
\hline gallon (gal) & 0.00379 & cubic meter $\left(\mathrm{m}^{3}\right)$ \\
\hline million gallons (Mgal) & 3,785 & cubic meter $\left(\mathrm{m}^{3}\right)$ \\
\hline ounce & 29.5735 & milliliter \\
\hline ounce & $29,573.50$ & microliter \\
\hline cubic inch $\left(\mathrm{in}^{3}\right)$ & 0.01639 & liter $(\mathrm{L})$ \\
\hline cubic foot $\left(\mathrm{ft}^{3}\right)$ & 0.02832 & cubic meter $\left(\mathrm{m}^{3}\right)$ \\
\hline cubic yard $\left(\mathrm{yd}^{3}\right)$ & 0.7646 & cubic meter $\left(\mathrm{m}^{3}\right)$ \\
\hline acre-foot (acre-ft) & 1,233 & cubic meter $\left(\mathrm{m}^{3}\right)$ \\
\hline \multicolumn{3}{|c|}{ Mass } \\
\hline ounce & 28.3495 & gram \\
\hline pound & 0.45359 & kilogram \\
\hline \multicolumn{3}{|c|}{ Speed } \\
\hline inch/second & 2.54 & centimeter/second \\
\hline gallon per day (gal/d) & 0.00379 & cubic meter per day $\left(\mathrm{m}^{3} / \mathrm{d}\right)$ \\
\hline cubic foot per day $\left(\mathrm{ft}^{3} / \mathrm{d}\right)$ & 0.02832 & cubic meter per day $\left(\mathrm{m}^{3} / \mathrm{d}\right)$ \\
\hline \multicolumn{3}{|c|}{ Density } \\
\hline ounces per gallon & $7,489.15$ & milligram/liter \\
\hline ounces per gallon & $7,489.15$ & microgram/milliliter \\
\hline ounces per gallon & $7.49 \mathrm{E}+09$ & nanogram/liter \\
\hline
\end{tabular}

Temperature in degrees Celsius $\left({ }^{\circ} \mathrm{C}\right)$ may be converted to degrees Fahrenheit $\left({ }^{\circ} \mathrm{F}\right)$ as follows:

$$
{ }^{\circ} \mathrm{F}=\left(1.8 x^{\circ} \mathrm{C}\right)+32
$$


Temperature in degrees Fahrenheit $\left({ }^{\circ} \mathrm{F}\right)$ may be converted to degrees Celsius $\left({ }^{\circ} \mathrm{C}\right)$ as follows:

$$
{ }^{\circ} \mathrm{C}=\left({ }^{\circ} \mathrm{F}-32\right) / 1.8
$$

*Transmissivity: The standard unit for transmissivity is cubic foot per day per square foot times foot of aquifer thickness [(ft3/d)/ft2]ft. In this report, the mathematically reduced form, foot squared per day (ft2/d), is used for convenience.

Specific conductance is given in microsiemens per centimeter at 25 degrees Celsius $(\mu \mathrm{S} / \mathrm{cm}$ at $\left.25^{\circ} \mathrm{C}\right)$.

Concentrations of chemical constituents in water are given either in milligrams per liter (mg/L) or micrograms per liter $(\mu \mathrm{g} / \mathrm{L})$.

NOTE TO USGS USERS: Use of hectare (ha) as an alternative name for square hectometer $(\mathrm{hm} 2)$ is restricted to the measurement of small land or water areas. Use of liter (L) as a special name for cubic decimeter $(\mathrm{dm} 3)$ is restricted to the measurement of liquids and gases. No prefix other than milli should be used with liter. Metric ton (t) as a name for megagram (Mg) should be restricted to commercial usage, and no prefixes should be used with it.

SI to Inch/Pound

\begin{tabular}{|c|c|c|}
\hline Multiply & By & To obtain \\
\hline \multicolumn{3}{|c|}{ Length } \\
\hline centimeter $(\mathrm{cm})$ & 0.3937 & inch (in.) \\
\hline millimeter (mm) & 0.03937 & inch (in.) \\
\hline meter (m) & 3.281 & foot $(\mathrm{ft})$ \\
\hline kilometer (km) & 0.6214 & mile (mi) \\
\hline kilometer (km) & 0.54 & mile, nautical (nmi) \\
\hline meter (m) & 1.094 & yard (yd) \\
\hline micrometer & 3.94E-05 & inch \\
\hline \multicolumn{3}{|c|}{ Area } \\
\hline hectare & 2.47105 & acre \\
\hline square kilometer $\left(\mathrm{km}^{2}\right)$ & 247.1 & acre \\
\hline centimeter per second & 0.3937 & Inch/second \\
\hline square kilometer $\left(\mathrm{km}^{2}\right)$ & 0.3861 & Square mile $\left(\mathrm{mi}^{2}\right)$ \\
\hline \multicolumn{3}{|c|}{ Volume } \\
\hline cubic meter $\left(\mathrm{m}^{3}\right)$ & 6.29 & barrel (petroleum, 1 barrel $=42$ gal) \\
\hline cubic meter $\left(\mathrm{m}^{3}\right)$ & 0.00026 & million gallons (Mgal) \\
\hline liter (L) & 33.82 & ounce, fluid (fl. oz) \\
\hline liter $(\mathrm{L})$ & 2.113 & pint (pt) \\
\hline liter (L) & 1.057 & quart (qt) \\
\hline liter (L) & 0.2642 & gallon (gal) \\
\hline liter $(\mathrm{L})$ & 61.02 & cubic inch $\left(\right.$ in $\left.^{3}\right)$ \\
\hline cubic meter $\left(\mathrm{m}^{3}\right)$ & 264.2 & gallon (gal) \\
\hline microliter & $3.38 \mathrm{E}-05$ & ounce \\
\hline milliliter & 0.03381 & ounce \\
\hline
\end{tabular}




\begin{tabular}{lcl}
\hline nanograms per liter & $1.60 \mathrm{E}-10$ & ounce/gallon \\
micrograms per kilogram & $=$ & micrograms/liter \\
milligrams per liter & 0.00013 & ounce/gallon \\
micrograms per milliliter & 0.00013 & ounce/gallon \\
cubic meter $\left(\mathrm{m}^{3}\right)$ & 35.31 & cubic foot $\left(\mathrm{ft}^{3}\right)$ \\
cubic meter $\left(\mathrm{m}^{3}\right)$ & 1.308 & cubic yard $\left(\mathrm{yd}^{3}\right)$ \\
cubic meter $\left(\mathrm{m}^{3}\right)$ & 0.00081 & acre-foot $(\mathrm{acre}-\mathrm{ft})$ \\
\hline \multicolumn{3}{c}{} \\
\hline cubic meter per day $\left(\mathrm{m}^{3} / \mathrm{d}\right)$ & Flow rate \\
cubic meter per day $\left(\mathrm{m}^{3} / \mathrm{d}\right)$ & 35.31 & cubic foot per day $\left(\mathrm{ft}^{3} / \mathrm{d}\right)$ \\
\hline & 264.2 & gallon per day $(\mathrm{gal} / \mathrm{d})$ \\
\hline gram $(\mathrm{g})$ & Mass & \\
kilogram $(\mathrm{kg})$ & 0.03527 & ounce, avoirdupois $(\mathrm{oz})$ \\
\hline
\end{tabular}

Temperature in degrees Celsius $\left({ }^{\circ} \mathrm{C}\right)$ may be converted to degrees Fahrenheit $\left({ }^{\circ} \mathrm{F}\right)$ as follows:

$$
{ }^{\circ} \mathrm{F}=\left(1.8 x^{\circ} \mathrm{C}\right)+32
$$

Temperature in degrees Fahrenheit $\left({ }^{\circ} \mathrm{F}\right)$ may be converted to degrees Celsius $\left({ }^{\circ} \mathrm{C}\right)$ as follows:

$$
{ }^{\circ} \mathrm{C}=\left({ }^{\circ} \mathrm{F}-32\right) / 1.8
$$

*Transmissivity: The standard unit for transmissivity is cubic foot per day per square foot times foot of aquifer thickness [(ft $\left.\left.\mathrm{ft}^{3} \mathrm{~d}\right) / \mathrm{ft}^{2}\right] \mathrm{ft}$. In this report, the mathematically reduced form, foot squared per day $\left(\mathrm{ft}^{2} / \mathrm{d}\right)$, is used for convenience.

Specific conductance is given in microsiemens per centimeter at 25 degrees Celsius $(\mu \mathrm{S} / \mathrm{cm}$ at $\left.25^{\circ} \mathrm{C}\right)$.

Concentrations of chemical constituents in water are given either in milligrams per liter (mg/L) or micrograms per liter $(\mu \mathrm{g} / \mathrm{L})$. 


\section{Words Used in Text}

4-Octylphenol

ANOVA

AP

BDE

Benzophenone

$\mathrm{C}$

Cashmeran (DPMI)

Celestolide (ADBI)

Cholesterol

DCPA

DEET

Di (2-ethylhexyl) phthalate (DEHP)

Diethyl phthalate

DO

E2

EDC

Ethyl citrate

Galaxolide (HHCB)

GC

GI

GSI

$\mathrm{HCH}$

HIS

$\mathrm{mM}$

$\mathrm{mL}$

$\mathrm{mOsm} / \mathrm{kg}$

$\mathrm{ng} / \mathrm{g}$

$\mathrm{OC}$

OWC

o,p'-DDD

o,p'-DDE

o,p'-DDT

OWC

\section{Alternative Names ${ }^{\mathrm{a}}$}

4-octylphenol

Analysis of Variance

Alkylphenols

brominated diphenyl ethers

Diphenylmethanone

Centigrade

1,1,2,3,3-pentamethyl-2,5,6,7-tetrahydroinden-4-one

1-(1,1-dimethyl-6-tert-butyl-2,3-dihydroinden-4-yl)ethanone

(3S, 8S,9S,10R,13R,14S,17R)-10,13-dimethyl-17-[(2R)-

6-methylheptan-2-yl]-2,3,4,7,8,9,11,12,14,15,16,17-

dodecahydro-1H-cyclopenta[a]phenanthren-3-ol

dimethyl 2,3,5,6-tetrachlorobenzene-1,4-dicarboxylate

N,N-diethyl-2-methyl-benzamide

bis(2-ethylhexyl) benzene-1,2-dicarboxylate

diethyl benzene-1,2-dicarboxylate

Dissolved oxygen

17ß-estradiol

Endocrine disrupting chemicals

1,2,3-triethyl 2-hydroxypropane-1,2,3-tricarboxylate

Galaxolide (no IUPAC name available)

Gas chromatography

Gonopodial index

Gonadosomatic index

1,2,3,4,5,6-hexachlorocyclohexane

Hepatosomatic index

Millimolar

Milliliter

milliosmole per kilogram

nanogram per gram

Organochlorine

Organic wastewater chemicals

1-chloro-2-[2,2-dichloro-1-(4-chlorophenyl)ethenyl]benzene

1-chloro-2-[2,2-dichloro-1-(4-chlorophenyl)ethenyl]benzene

1-chloro-2-[2,2,2-trichloro-1-(4-chlorophenyl)ethyl]benzene

Organic wastewater chemicals 


\begin{tabular}{|c|c|}
\hline p,p'-DDD & 1-chloro-4-[2,2-dichloro-1-(4-chlorophenyl)ethyl]benzene \\
\hline p,p'-DDE & 1-chloro-4-[2,2-dichloro-1-(4-chlorophenyl)ethenyl]benzene \\
\hline $\mathrm{p}, \mathrm{p}{ }^{\prime}-\mathrm{DDT}$ & 1-chloro-4-[2,2,2-trichloro-1-(4-chlorophenyl)ethyl]benzene \\
\hline PCA & 3-amino-2H-pyrazole-4-carboxamide \\
\hline $\mathrm{PCB}$ & Polychlorinated biphenyl \\
\hline Phantolide (AHMI) & 1-(1,1,2,3,3,6-hexamethyl-2H-inden-5-yl)ethanone \\
\hline $\mathrm{p} / \mathrm{g}$ & Picogram per gram \\
\hline POCIS & Polar organic chemical integrative samplers \\
\hline Prometon & 6-methoxy-N,N'-dipropan-2-yl-1,3,5-triazine-2,4-diamine \\
\hline p-tert-Octylphenol & 4-(2,4,4-trimethylpentan-2-yl)phenol \\
\hline $\mathrm{R}$ & Ray of a gonopodium \\
\hline S & S of a gonopodium \\
\hline SAR & Santa Ana River \\
\hline SPMD & Semipermeable membrane device \\
\hline $\mathrm{T}$ & Testosterone \\
\hline TIE & Toxicity identification and evaluation \\
\hline ТСРP & chlorinated tris-propylphosphates \\
\hline TL & Total length \\
\hline Tonalide (AHTN) & 1-(3,5,5,6,8,8-hexamethyltetralin-2-yl)ethanone \\
\hline Traseolide (ATII) & $\begin{array}{l}\text { 1-(1,1,2,6-tetramethyl-3-propan-2-yl-2,3-dihydroinden-5-yl) } \\
\text { ethanone }\end{array}$ \\
\hline Tri(2-chloroethyl) phosphate & 1-[bis(2-chloroethoxy)phosphoryloxy]-2-chloro-ethane \\
\hline Tri(butoxyethyl) phosphate & 1-[2-[bis(2-butoxyethoxy)phosphoryloxy]ethoxy]butane \\
\hline Tri(dichloroisopropyl) phosphate & tris(1,3-dichloropropan-2-yl) phosphate \\
\hline Tributyl phosphate & 1-dibutoxyphosphoryloxybutane \\
\hline Triphenyl phosphate & Diphenoxyphosphoryloxybenzene \\
\hline TTWE & Tertiary treated wastewater effluent \\
\hline USGS & United States Geological Survey \\
\hline Ww & wet weight \\
\hline WWTP & Wastewater treatment plant \\
\hline YES & Yeast estrogen screen \\
\hline
\end{tabular}

${ }^{a}$ Contaminant acronyms available as International Union of Pure and Applied Chemistry (IUPAC) terms are provided. 


\title{
Effects of Wastewater Discharges on Endocrine and Reproductive Function of Western Mosquitofish (Gambusia spp.) and Implications for the Threatened Santa Ana Sucker (Catostomus santaanae)
}

\author{
By Jill A. Jenkins, ${ }^{1}$ Steven L. Goodbred, ${ }^{2}$ Scott A. Sobiech, ${ }^{3}$ Heather M. Olivier, ${ }^{4}$ Rassa O. Draugelis-Dale, ${ }^{1}$ and \\ David A. Alvarez ${ }^{5}$
}

\section{Abstract}

The Santa Ana River in southern California is impacted by effluents from wastewater treatment plants (WWTP), which are sources of organic wastewater compounds (OWCs) and urban runoff. The Santa Ana River is one of only three river basins supporting native populations of the federally listed Santa Ana sucker (Catostomus santaanae) at the time the fish was included on the list 2000. In 2004 and 2005, a U.S. Geological Survey and U.S. Fish and Wildlife Service study was undertaken to determine if the threatened Santa Ana sucker was potentially exposed to OWCs and endocrine disrupting compounds (EDCs) in the SAR by using the western mosquitofish (Gambusia affinis) as a surrogate fish model. Four Santa Ana River sites were chosen along a gradient of proximity to WWTP effluents: (1) a point source of tertiary treated wastewater effluent (TTWE), (2) Rialto Drain (just below a WWTP), (3) Prado Dam (11 kilometers [km] below WWTPs), and (4) Sunnyslope Creek (no WWTP but having urban runoff influence). A reference site having no WWTPs or urban runoff, Thousand Palms, was also sampled. Chemical analyses of passive sampler extracts results showed that 15 OWCs and EDCs were detected in water from the Santa Ana River sites. Many of these compounds contributed to activity from an estrogenic in-vitro assay that showed a significant potential for impacting endocrine and reproductive systems compared to the 25 organochlorine compounds detected in aquatic biota. The site showing compounds having highest influence on sex steroid hormone activities was the point source for TTWE. Sex steroid hormone levels, secondary sex characteristics, organosomatic indices, and sperm quality parameters indicated impairment of endocrine and reproductive function of male western mosquitofish in

${ }^{1}$ USGS National Wetlands Research Center, Lafayette, La.

${ }^{2}$ USGS Emeritus Scientist, Sacramento, Calif.

${ }^{3}$ U.S. Fish and Wildlife Service Environmental Contaminants Division, Carlsbad, Calif.

${ }^{4}$ IAP World Services at the National Wetlands Research Center, Lafayette, La ${ }^{5}$ USGS Columbia Environmental Research Center, Columbia, Mo. the Santa Ana River. Exposure to EDCs and consequent impairment in mosquitofish followed the gradient of proximity to WWTP effluents, where the most significant effects were found at TTWE point source and Rialto Drain, followed by Prado Dam and Sunnyslope Creek. Each of these sites is suitable habitat for the Santa Ana sucker, especially Sunnyslope Creek and Rialto Drain where juveniles reside. Various OWCs and EDCs were detected at each Santa Ana River site, although one specific compound or group of compounds could not be singled out as a causative factor. Di (2-ethylhexyl) phthalate was strongly negatively correlated with testosterone in male mosquitofish. One group of potent environmental estrogens that likely contributed to endocrine and reproductive impairment are the natural and synthetic estrogen hormones, especially ethinyl estradiol; however, this compound was not targeted in these investigations. The multiple lines of evidence for impaired reproductive and endocrine function in western mosquitofish due to OWCs and EDCs from the Santa Ana River can be used to identify potential problems for the Santa Ana sucker inhabiting the same and nearby sites.

\section{Introduction}

Over the last 20 years, studies on physiological processes in fish have linked sewage and wastewater effluents to altered biological responses, including endocrine disruption (Kosmala and others, 1998; Nichols and others, 1999; Bernet and others, 2000; Hemming and others, 2001; Angus and others, 2002; Alberto and others, 2005; Leusch and others, 2006). Disruption occurs when endocrine disrupting compounds (EDCs) alter function of the endocrine system to cause adverse effects in organisms, progeny, or subpopulations (Vos and others, 2000). EDCs in effluents can include natural and synthetic estrogens, xenoestrogens such as pesticides, and emerging contaminants (Petrovic and others, 2004) routinely detected in treated wastewater effluents (Snyder and others, 1999, Kolpin and others, 2002, Gross and others, 
2004; Osemwengie and Gerstenberger, 2004) including pharmaceuticals (Gross and others, 2004) and personal care products (Daughton and Ternes, 1999; Kolpin and others, 2002; Ishibashi and others, 2004; Nakada and others, 2006; Chen and others, 2007).

These compounds are of particular concern in streams that are highly urbanized and receive significant flows from wastewater treatment plant (WWTP) effluents, as in the case of the Santa Ana River (SAR), Calif. While laboratory studies can sometimes show clear causal links with environmentally realistic concentrations of xenobiotics, such associations are less readily apparent from field studies because of multiple confounding ecological parameters (Vos and others, 2000; Alberto and others, 2005; Mills and Chichester 2005).

A national reconnaissance study of pharmaceuticals, hormones, and other organic wastewater compounds (OWCs) surveyed 139 streams and reported that 80 percent of them had at least one OWC occurring at low levels (Kolpin and others, 2002). The individual and interactive effects of these compounds are, as yet, not well known. In a study of the occurrence and fate of pharmaceuticals and alkylphenol ethoxylates (widely used nonionic surfactants), several were detected at four major WWTPs discharging into the SAR, although concentrations were significantly attenuated 11 kilometers $(\mathrm{km})$ downstream after diversion of flow through the Prado wetlands (Gross and others, 2004). Inputs into the SAR are of particular ecological concern because of the river's function in recharging aquifers used as a drinking water source and because it is one of only a few habitats sustaining the federally threatened Santa Ana sucker (Catostomus santaanae) (Federal Register, 2000) (fig. 1). Saiki and others (2007) found marginally healthy populations of the Santa Ana sucker in the SAR, where fish rarely reach 2 years of age compared to other populations located in the San Gabriel River where they commonly reach 3 years of age. Within the SAR main stem, the most important deme of Santa Ana suckers is a 7 $\mathrm{km}$ stretch of river just below Rialto Drain, downstream to Mission Road. The sites found to be most supportive for reproduction were within Sunnyslope Creek and Rialto Drain (Haglund and others, 2001).

The Santa Ana sucker, a relatively small fish (approximately 200 millimeters [mm] standard length), lives up to 3 or 4 years in streams of good quality (Saiki, 2000). However, its historic range has been greatly reduced (Federal Register, 2000). Critical habitat protection was established in the SAR for this species in 2005 (Federal Register, 2004), whereby this conservation strategy is appropriate with nongame catostomids (Cooke and others, 2005). Because field sampling of federally listed fish species is generally allowed only when nondestructive or noninvasive in nature, investigations into potential endocrine impacts are limited. Therefore, studies using surrogate animal models are appropriate and preferable approaches, especially when the surrogates inhabit similar environments and display similar life histories.

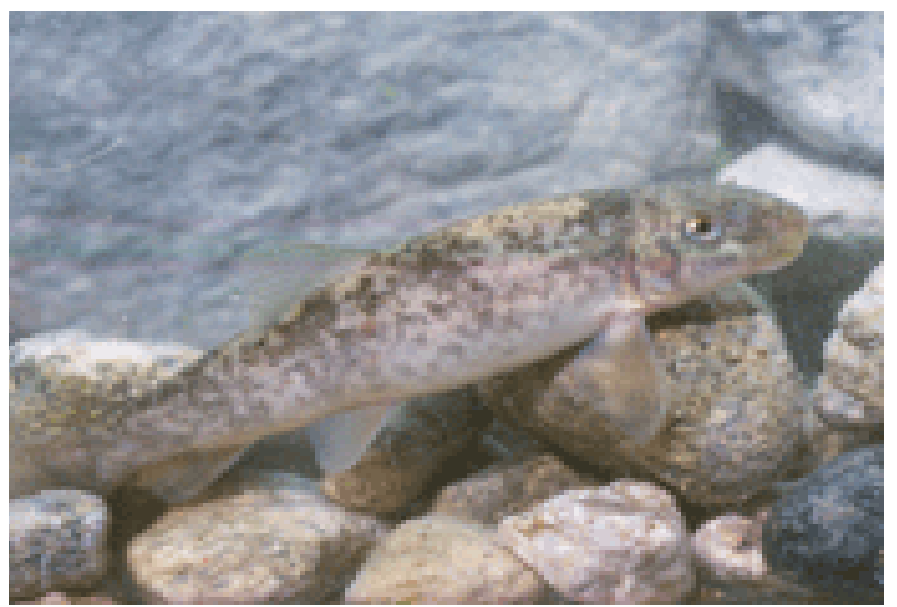

Figure 1. Federally threatened Santa Ana sucker (Catostomus santaanae Snyder). Photograph taken by Paul Barrett, USFWS.

Mosquitofish (Gambusia species) are live-bearing poecilids ubiquitous around the world (Meffe and Snelson, 1989), and they exhibit a high degree of site tenacity (Feder and others, 1984). Therefore, their responses reflect exposure and effects of water quality close to their collection site. These fish are easily gathered from the wild, are usually abundant, and are tolerant of a wide range of environmental conditions (Orlando and others, 2003). Western mosquitofish (Gambusia affinis) occur in large numbers in the SAR (Saikiand others, 2007). Poecilids have characteristics making them well-suited for documenting exposure to endocrine-modulating substances (Bortone and Davis, 1994; Bayley and others, 2002). Mosquitofish exhibit hormonedependent sexual dimorphism (Doyle and Lim, 2002) in that males are smaller than females and possess a modified anal fin (gonopodium) used to transfer sperm during copulation. Development of gonopodia is under androgenic control, and the fin has shown to be a useful bioindicator for quantifying effects of known or suspected environmental androgens (Angus and others, 2001).

Many OWCs are EDCs because they bind to estrogen receptors (Nishihara and others, 2000). Evidence to date has suggested that exposure to potent steroidal estrogens is the primary cause of endocrine disruption in fish, particularly the feminization of males (Sumpter and Johnson, 2005). Because the reproductive physiology of vertebrates is similar, cross-taxa comparisons are relevant (Mills and Chichester, 2005). Feminization can occur after exposure to estrogenic compounds, causing alterations in sex steroid hormone profiles, sperm quality, and secondary sex characteristics (Kime, 1998). Complicating the interpretation of biomarkers from field studies is the fact that animals are exposed to multiple EDCs simultaneously along with emerging compounds that may interact, resulting in unknown synergisms and modes of action (Ropero and others, 2006). Because synthetic sex steroid hormones, like ethinyl estradiol (the active ingredient in oral contraceptives), can occur at 
extremely low levels (nanogram per liter [ng/L] concentrations and lower) (Ying and others, 2002), novel and sensitive methods are being developed to detect such environmental estrogenic compounds. For example, chemical extracts from passive samplers that integrate and concentrate environmental contaminants over time are now being tested for estrogenicity by in vitro assays such as yeast estrogen screens (YES) that use recombinant yeast transfected with the human estrogen receptor (Petty and others, 2004; Vermeirssen and others, 2005; Alvarez and others, 2007a,b). Additionally, a toxicity identification and evaluation (TIE) process can be used through which environmental samples are fractionated based on the chemical properties of individual components of the sample. Each fraction is then screened by the YES, and chemical analyses are performed only on the hormonally active fractions (Nakada and others, 2004; Alvarez and others, 2007b).

The objective of this study was to determine if threatened Santa Ana suckers were potentially exposed to OWCs in the SAR by using the western mosquitofish as a surrogate. During 2004, evidence of exposure to OWCs and EDCs was determined by measuring environmental contaminants in aquatic biota from four sites in the SAR basin and from one reference site. In 2004 and 2005, evidence of endocrine disruption was assessed in western mosquitofish by analyzing sex steroid hormones, secondary sex characteristics, organosomatic indices, and sperm quality parameters. In 2005 , waters from four sites and one reference site were sampled by using passive samplers, and a TIE was performed to determine if OWCs may have been present that were capable of hormonal activity. Excerpts of the TIE results are included in this report, with the full results reported in Alvarez and others (2007b).

\section{Materials and Methods}

\section{Study Area}

The SAR basin is the largest in southern California (fig. 2 ), encompassing about $6,900 \mathrm{~km}^{2}$ of the densely populated coastal area (Brown and others, 2005). The human population within the basin is close to 5 million and is expected to reach nearly 7 million by 2025 (Santa Ana Watershed Project

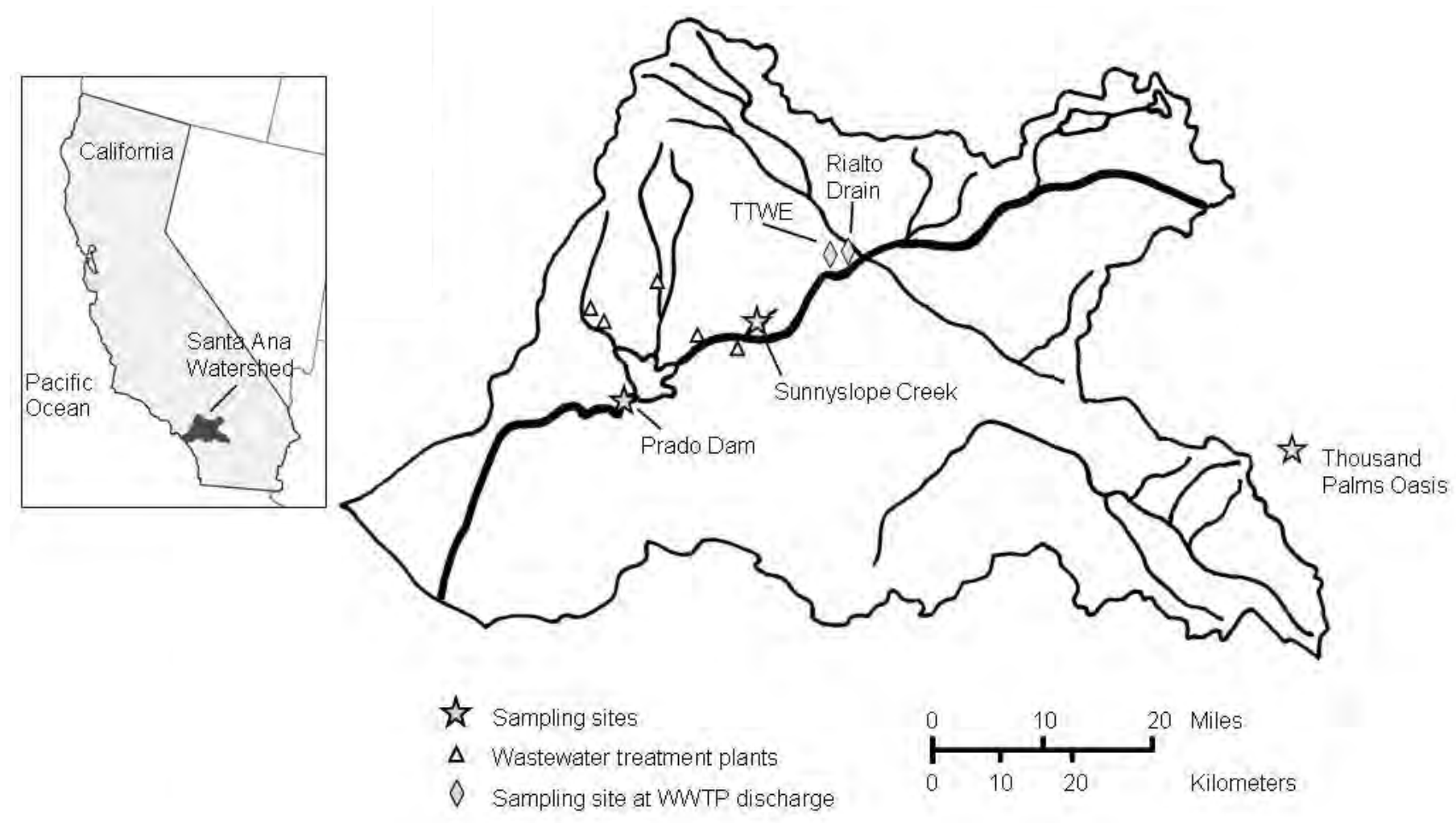

Figure 2. Sampling sites in the Santa Ana River watershed, Calif., showing proximity to wastewater treatment plants (WWTP) and a source point for tertiary treated wastewater effluents (TTWE). Diamonds show sites in or very close to WWTPs that are dominated by wastewater effluent; stars show sites farther away from WWTPs that are less dominated by wastewater effluent; triangles show major wastewater treatment plants. Thousand Palms, the reference site, is outside of the watershed, located between the San Jacinto and San Bernardino mountain ranges, and is not influenced by any WWTP. 
Authority, 2003). Overall, the basin's land area is mostly open space ( 55 percent because of undeveloped steep slopes near the headwaters, 35 percent urban in the coastal plains and hills, and 10 percent agriculture (Brown and others, 2005). Although the SAR is only $160 \mathrm{~km}$ long, its flow is highly engineered. Diversions from headwater tributaries in the San Bernardino Mountains are used as public water supplies, and some main stem flow is diverted for generating hydroelectric power (Burton and others, 2005). Flow is reestablished in the mid reach of the river by urban runoff, discharges from 12 major WWTPs, and groundwater (Brown and others, 2005). In order to meet water-quality objectives in the basin, all municipal wastewater is currently tertiary treated, and about 50 percent of river flow is diverted to 130 ha of riparian wetlands north of Prado Dam to remove nitrates (Ding and others, 1999). Flows through these wetlands also remove trace organic compounds; however, this process increases dissolved organic carbon levels (Reinhard and Debroux, 2001). The SAR rarely releases to the Pacific Ocean because its annual discharge is diverted into lower river reaches for infiltration and recharge of underlying aquifers that are tapped as drinking water for almost 2 million people in Orange County (Burton and others, 1998). During the dry season (early spring to late fall), flow in the mid and lower reaches of the SAR is almost entirely WWTP effluent with little input from groundwater (Gross and others, 2004).

Two sampling sites for mosquitofish were below tertiary treated WWTP effluents, including those near a point source of tertiary-treated wastewater effluent (TTWE) and Rialto Drain. Discharges close to these wastewater effluent sources average 150,000 cubic meters per day $\left(\mathrm{m}^{3} / \mathrm{d}\right)$, where $26,000 \mathrm{~m}^{3} / \mathrm{d}$ is filtered in basins through sand and into underlying native soil before being discharged. Ultraviolet disinfection is used. The fish were collected in 2004 from the plunge pool directly below discharge and along the short channel of effluent (about 100 meters [m]) before it reached the SAR (fig. 3).

Rialto Drain receives an average discharge of 120,000 $\mathrm{m}^{3} / \mathrm{d}$ of tertiary treated effluent that is flocculated, filtrated, disinfected with chlorine gas, and then dechlorinated with $\mathrm{SO}_{2}$. In 2004, western mosquitofish, bullfrog tadpoles (American

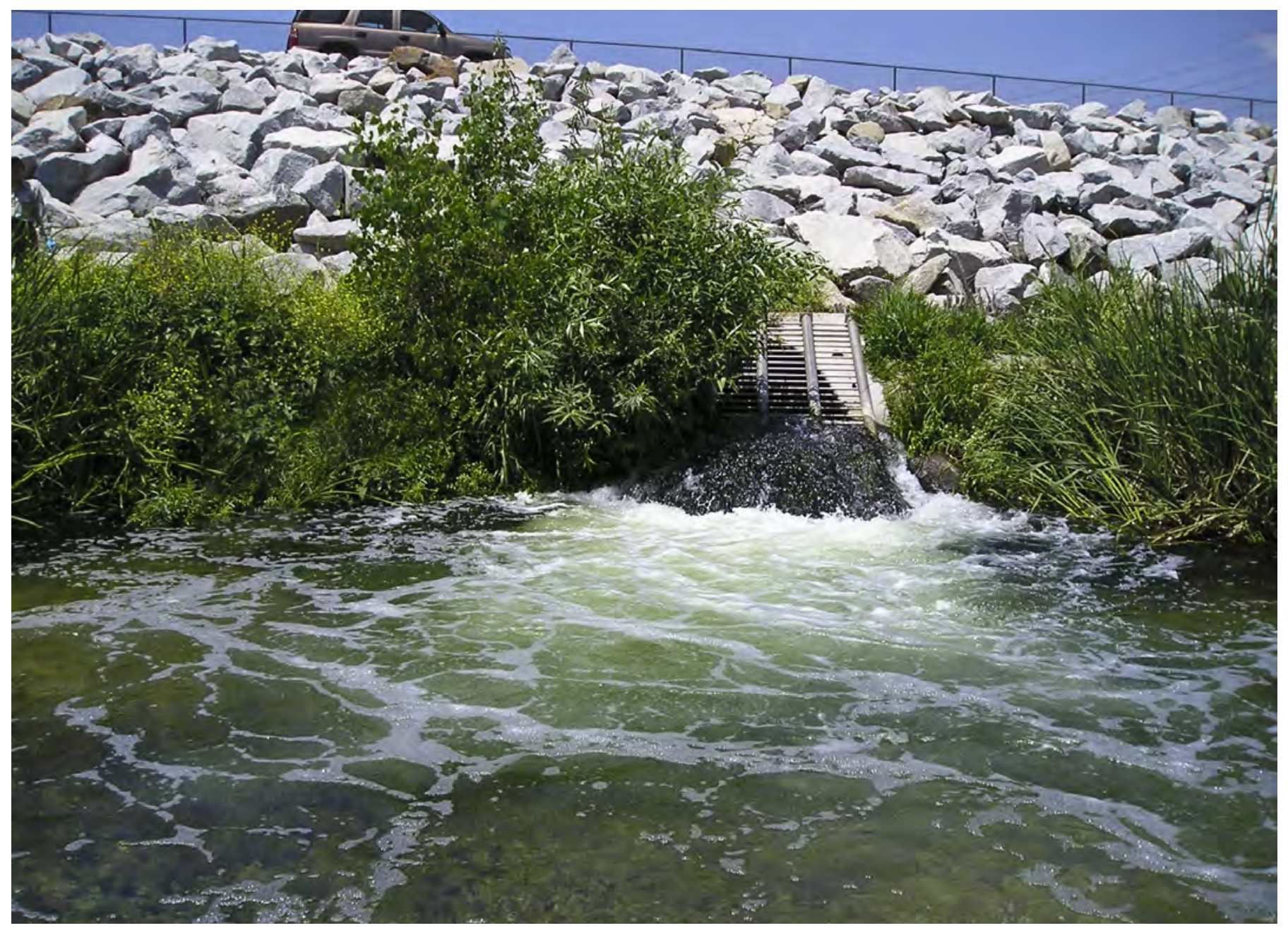

Figure 3. Plunge pool below a discharge site for tertiary treated wastewater effluent, Colton, Calif. Photograph by Judy Gibson. 
bullfrog, Lithobates catesbeianus), and tilapia (Tilapia zilli and Oreochromis mossambicus) were collected from a small drainage channel (approximately $3 \mathrm{~m}$ wide) below West Agua Mansa Road in Colton, Calif., downstream for about $500 \mathrm{~m}$ to the confluence of the SAR (fig. 4).

Prado Dam is a large rock-filled dam (32 $\mathrm{m}$ high, $695 \mathrm{~m}$ long) near Corona, Calif., built by the U.S. Army Corps of Engineers in 1941. It was constructed to control stormflows and to release water at a controlled rate to maximize groundwater recharge for drinking water $21 \mathrm{~km}$ downstream (Gross and others, 2004). Behind the dam, an extensive willow riparian wetland has developed, facilitating nitrate removal. In 2004, western mosquitofish and bullfrog tadpoles were collected in a sediment control structure (fig. 5) below Prado Dam. In 2005, fish were collected within Prado wetlands (fig. 6).

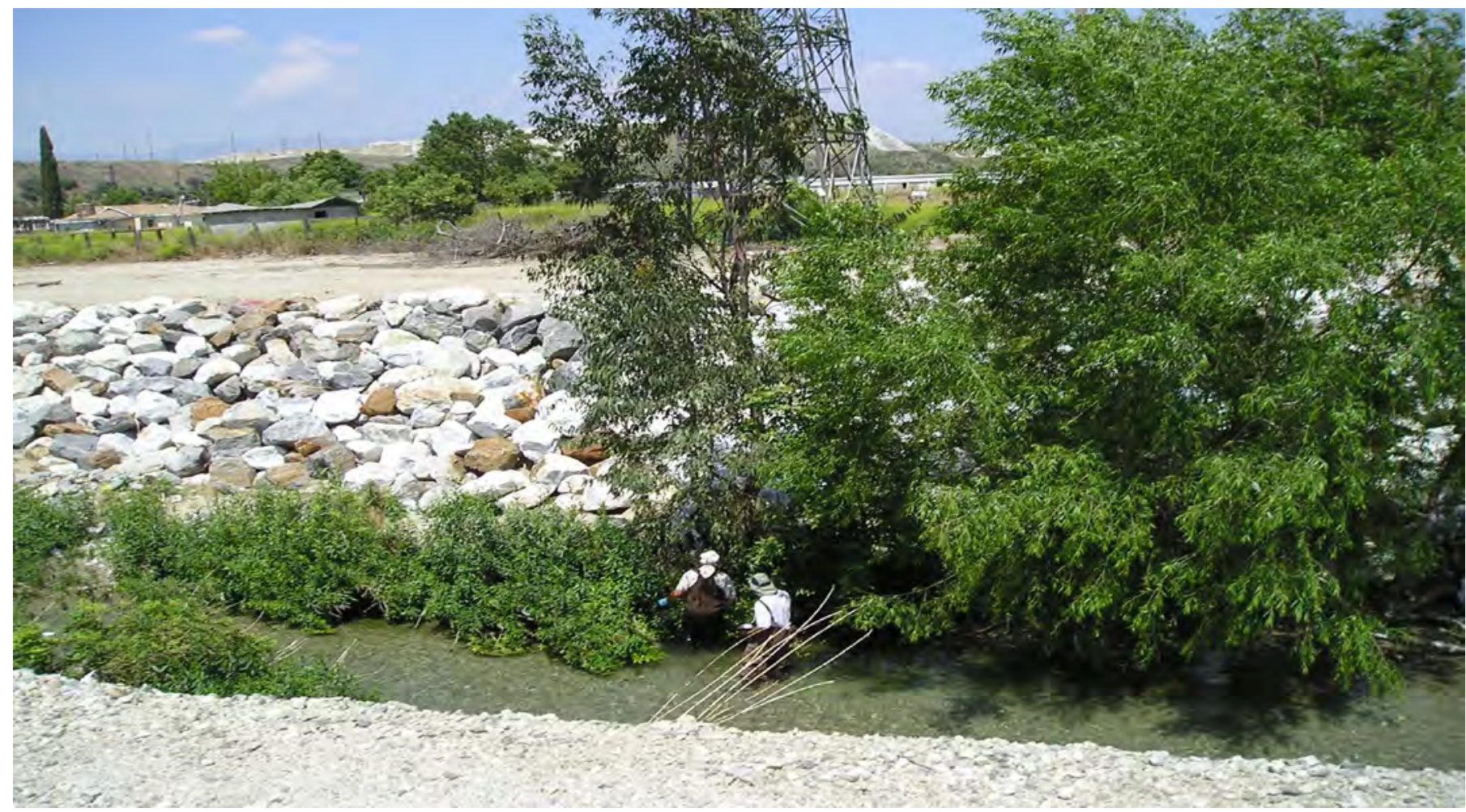

Figure 4. Rialto Drain below West Agua Mansa Road, Colton, Calif.

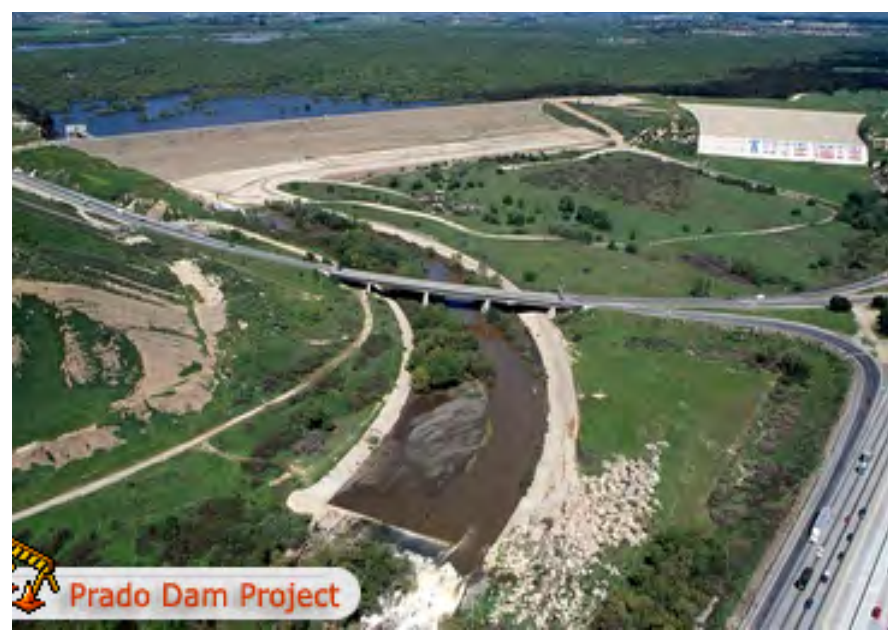

Figure 5. Sediment control structure below Prado Dam, near Corona, Calif.

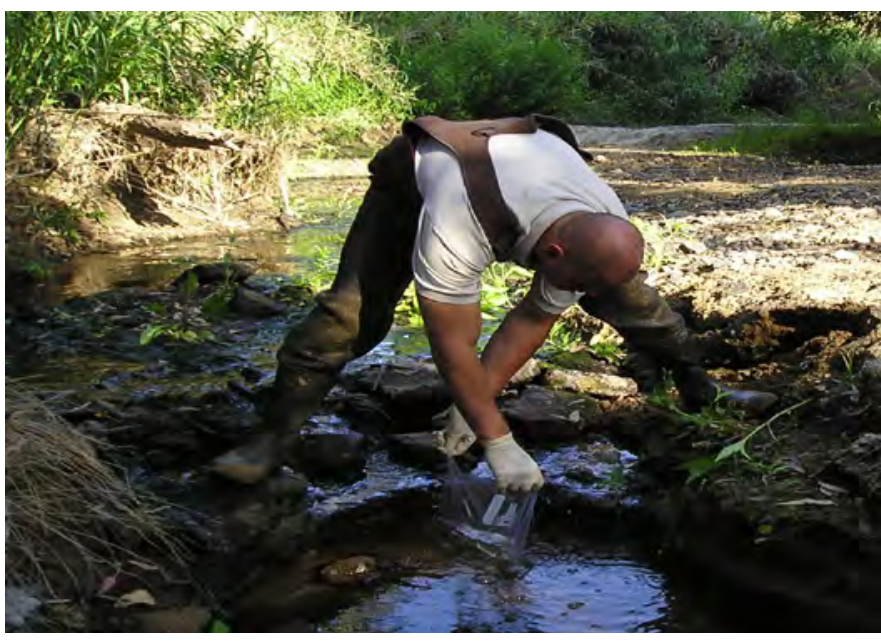

Figure 6. Small channel of Santa Ana River within wetlands near Prado Dam, close to Corona, Calif. 
Sunnyslope Creek has a small, 19 square kilometer $\left(\mathrm{km}^{2}\right)$ watershed with more than 50 percent urban land use where no WWTP effluent discharges occur. In many places, its banks are rip-rapped to prevent erosion, and a capped landfill is located where the mouth of one of its tributaries, Arroyo Tequesquite, enters. The specific area where western mosquitofish were collected in 2004 and 2005 was within the Rubidoux Nature Center in Riverside, Calif. (fig. 7).
Thousand Palms is a small desert spring in the Coachella Valley Preserve in Thousand Palms, Calif. The basin has no known sources of anthropogenic environmental contaminants other than atmospheric depositions. It has an established population of the endangered desert pupfish (Cyprinodon macularius), as well as western mosquitofish, which were collected in 2004 and 2005 for this study (fig. 8).

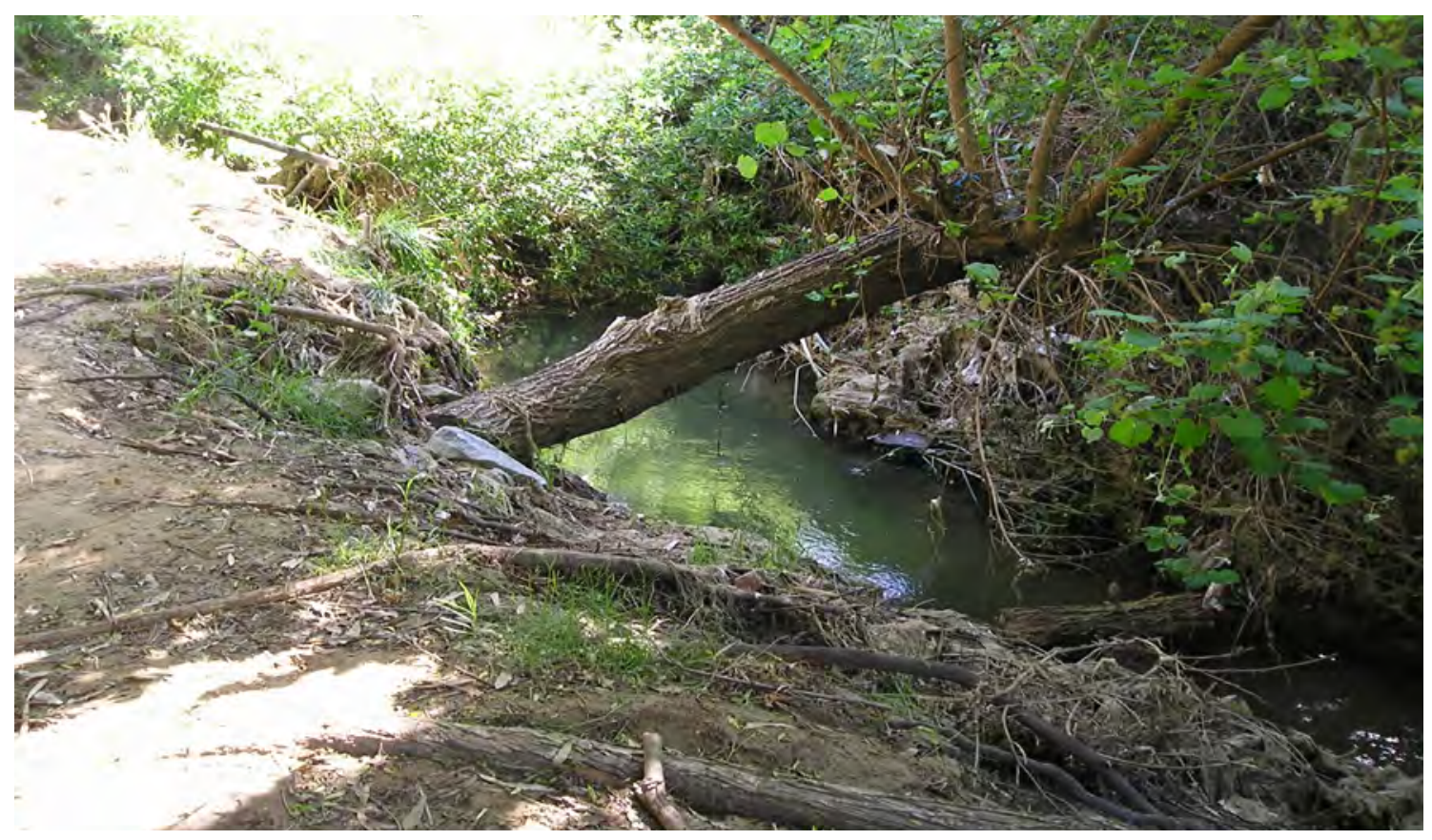

Figure 7. Sunnyslope Creek in the Rubidoux Nature Center, Riverside, Calif.

Figure 8. Thousand Palms in the Coachella Valley Preserve, Thousand Palms, Calif.

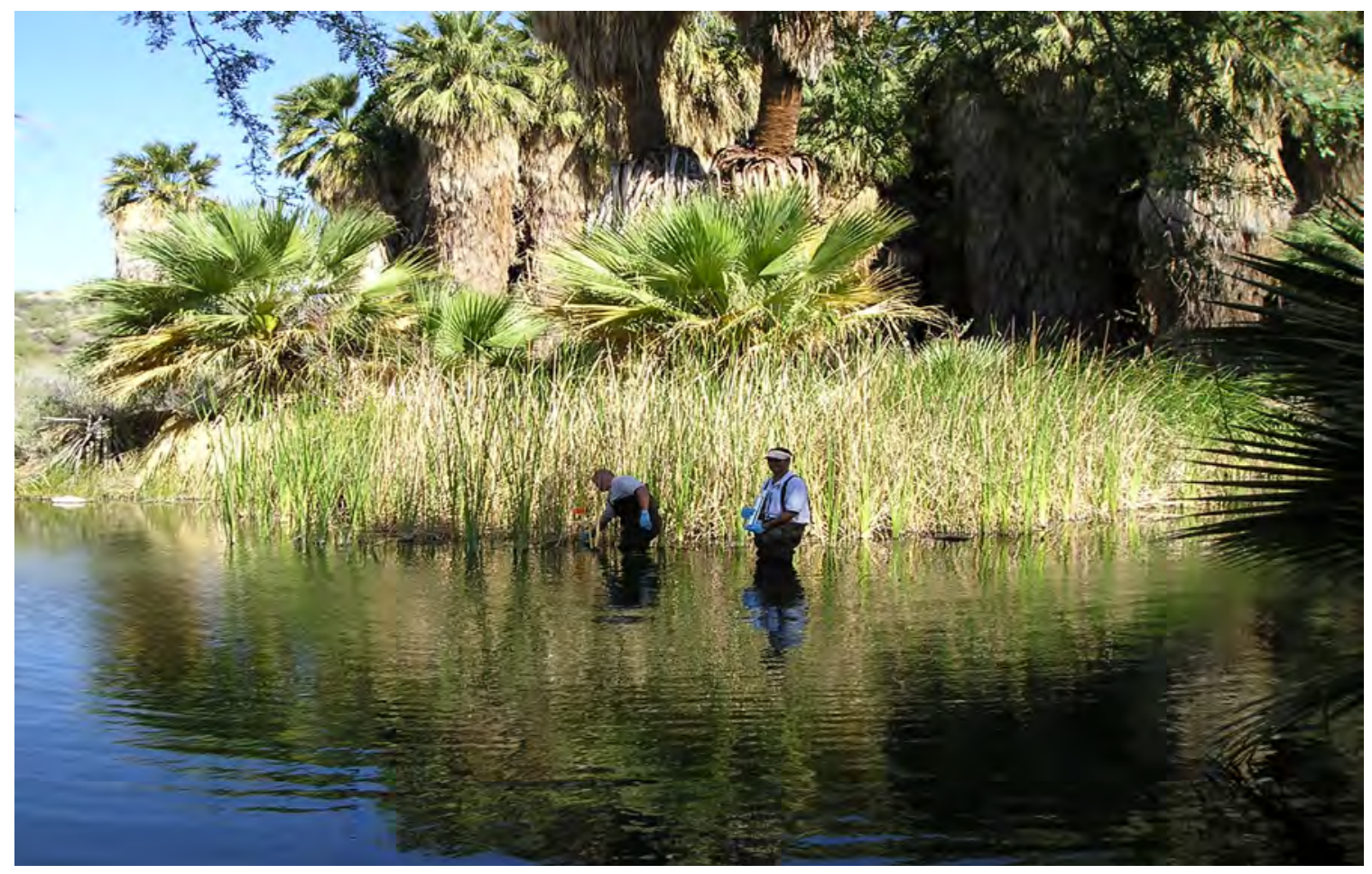




\section{Field Processing}

Male and female western mosquitofish were collected by using dip nets, minnow traps, and seines from four experimental sites in the SAR basin and one reference site at Thousand Palms in 2004 (June 7-10) (fig. 2). Sites were selected to provide varying degrees of potential exposure to OWCs: (1) maximum exposure below WWTP effluents at the point source for TTWE and Rialto Drain; (2) reduced exposure downstream from Prado wetlands; (3) exposure to only urban runoff at Sunnyslope Creek; and (4) minimal exposure at Thousand Palms. In 2005 (June 7-9), because the low water condition significantly altered flow in the stream channel, fish collections were possible only at Sunnyslope Creek, Prado Dam, and Thousand Palms. Also, in 2005, the Prado Dam collection site was located above the dam and within the Prado wetlands rather than below the dam, as in 2004. At each site, water-quality parameters of dissolved oxygen, temperature, $\mathrm{pH}$, and specific conductance were measured by using a Hydrolab Surveyor II calibrated according to U.S. Geological Survey (USGS) procedures. During 2004, composite samples of western mosquitofish were collected from the TTWE point source, Rialto Drain, Sunnyslope Creek, and Thousand Palms for chemical analyses (see below). Additionally in 2004, one composite of tilapia (Tilapia zilli and Oreochromis mossambicus) was collected from Rialto Drain, and tadpoles of the American bullfrog (Lithobates catesbeianus) were collected from Rialto Drain and Prado Dam.

At each collection, adult male $(n \geq 10)$ and female $(n \geq$ 10) western mosquitofish were placed in a 19 L bucket with site water, and individual adults were selected based on a minimum size of $20 \mathrm{~mm}$ total length (TL) for males and 31 $\mathrm{mm}$ TL for females (Lee and Burgess, 1980). Gonopodia were measured to the nearest $0.5 \mathrm{~mm}$ under a binocular dissecting scope by using $10 \mathrm{X}$ total magnification for segregation according to sex (Krumholz, 1948); then fish were weighed to the nearest $0.01 \mathrm{~g}$, and TL was measured to the nearest 0.5 $\mathrm{mm}$. Individuals to be used for sex steroid hormone analysis were placed in individual glass vials, frozen, and stored at $-20^{\circ} \mathrm{C}$ until shipment to the USGS Florida Integrated Science Center, Gainesville, Fla. All other fish (both sexes) were then pooled per site into chemically clean glass jars, batchweighed and stored at $-20^{\circ} \mathrm{C}$ until shipment for contaminant analyses at the USGS National Water Quality Laboratory (NWQL) in Denver, Colo. For sperm quality assessments, about 30 healthy and active adult male mosquitofish from each site were shipped overnight to the USGS National Wetlands Research Center (NWRC), Lafayette, La., in large oxygenated plastic bags (about 8 to12 per bag) inside insulated coolers with wet ice. If fish arrived dead and no decomposition was noted, fish TL, gonopodial lengths, and weights were obtained, in addition to measures for the live fish.

\section{Laboratory Processing}

\author{
Contaminants Analysis
}

\section{Aquatic Biota}

In 2004, at the point source of TTWE, Rialto Drain, Sunnyslope Creek, and at Thousand Palms, composite samples of male and female western mosquitofish were collected, being of random lengths and minimum weights of $15 \mathrm{~g}$. Composites were analyzed for 28 organochlorine compounds (OCs) having log octanol-water partition coefficients greater than 4 by using capillary-column gas chromatography (GC) and electron-capture detection (Leiker and others, 1996). In addition, the composites of tilapia from Rialto Drain and tadpoles from Prado Dam and Rialto Drain were chemically analyzed for 28 OCs. At NWQL, partially frozen samples were first homogenized with a commercial grinder into a uniformly fine grain size, then a 10-g aliquot was thoroughly mixed with $100 \mathrm{~g}$ of granular anhydrous sodium sulfate in order to remove water. To each sample, three surrogate compounds (decafluorobiphenyl, $\gamma$-hexachlorocyclohexane, and octachlorobiphenyl) and performance recovery spikes were added, followed by overnight Soxhlet extraction of the samples with methylene chloride. Each extract was concentrated to $5 \mathrm{~mL}$, and a 1-milliliter $(\mathrm{mL})$ aliquot was used for percent lipid determination. A 2-mL aliquot of the extract was injected into a gel permeation chromatograph to separate lipids and other interfering compounds from the surrogates and chemicals of interest, and solvent was exchanged into hexane. The extract was then separated into two fractions on a column packed with $1 \mathrm{~cm}$ of sodium sulfate, $5 \mathrm{~g}$ of 8.5 percent water-deactivated alumina, $3 \mathrm{~g}$ of 2 percent waterdeactivated silica, and $0.5 \mathrm{~cm}$ of sodium sulfate. The first fraction contained the polychlorinated biphenyls (PCBs), dichlorodiphenyldichloroethylene (DDE), and other nonpolar compounds, while the second fraction contained toxaphene, chlordane components, dichlorodiphenyltrichloroethane (DDT), dichlorodihenyldichloroethane (DDD), and other more polar compounds. Fractions were analyzed by dual capillarycolumn GC with electron-capture detection. Compounds were identified by comparing $\mathrm{GC}$ retention times on both capillary columns with those produced by the standard, external mixtures. Compounds were quantified by using calibration curves derived from standard, external mixtures. The reporting limits in wet weight were 5 micrograms per kilogram $(\mu \mathrm{g} / \mathrm{kg})$ for the chlorinated pesticides, $50 \mu \mathrm{g} / \mathrm{kg}$ for PCBs, and $200 \mu \mathrm{g} / \mathrm{kg}$ for toxaphene. Concentrations reported were obtained from the lower of the two responses obtained by the GC columns, except where recognized compound coelutions or interferences resulted in a single column 
quantitation (Leiker and others, 1996). Quality assurance parameters included solvent blanks, surrogate spikes, reagent spikes, and replicate tissue samples. Surrogate and reagent recoveries were within acceptable levels according to methods performance standards (Leiker and others, 1996).

\section{Passive Samplers}

In 2005, two types of passive samplers were used to assess the environmental contaminants to which aquatic biota might have been exposed within the water column. Polar organic chemical integrative samplers (POCIS) were used to sample hydrophilic compounds such as pharmaceuticals, personal care products, hormones, and newer generation pesticides having low $\log n$-octanol-water partition coefficents $\left(\mathrm{K}_{\mathrm{ow}} \mathrm{s}<3\right)$. The POCIS were prepared according to established procedures (Alvarez and others, 2004, 2007a). Oasis hydrophilic-lipophilic balanced, a solid sorbent used to trap chemicals from the surrounding water, was placed between two sheets of a microporous polyethersulfone membrane, which was secured by two stainless steel discs. Semipermeable membrane devices (SPMDs) were used to sample the bioaccumulative hydrophobic organic chemicals with $\log \mathrm{K}_{\mathrm{ow}} \mathrm{s}>3$ (Huckins and others, 2006). SPMDs are layflat polyethylene membrane tubes that contain a purified lipid (triolein).

The POCIS and SPMDs were secured in stainless steel deployment devices and stored at $<0^{\circ} \mathrm{C}$ until use. Each site was assessed for proper placement of the passive samplers, where a location would have at least 1 centimeter per second $(\mathrm{cm} / \mathrm{sec})$ of velocity but not too much current, whereby floating debris could cause damage. Locations needed enough water depth so if streamflow decreased during the deployment period, the samplers would not be exposed to air. When a location with minimal chances of vandalism was found, a section of $1-\mathrm{cm}$ rebar that was $1 \mathrm{~m}$ long was pounded into the substrate, and the samplers to be deployed were taken out of the sealed containers, placed quickly underwater, and attached to the rebar with a plastic tie by using latex gloves during all handling. A field blank containing SPMDs and POCIS was opened at each site during deployment and retrieval in order to account for potential atmospheric contamination.

After 26-28 days of deployment (between May 10 and11 and June 6 and 7,2005), wire cutters were used to cut the plastic tie of the samplers in the stream, and the samplers were removed from the stream and cleaned of sediment and debris, quickly replaced in their sealed carriers, chilled in a cooler, and shipped to Columbia Environmental Research Center, Columbia, Mo., for extraction and enrichment according to procedures in Alvarez and others (2004, 2007a) and Huckins and others (2006). Each POCIS was rinsed under warm running water to remove any material on the membrane surface and opened carefully. Environmental contaminants were recovered from the POCIS by solvent extraction with methanol. SPMDs were similarly cleaned to remove any debris and biofilm from the surface, followed by recovery of the sampled chemicals using a dialysis process into hexane. Dialysates from SPMDs were then enriched using gel permeation chromatography to remove any co-extracted matrix interferences and sulfur.

The GC analyses for selected chemicals related to wastewater effluent in the POCIS (fig. 9) and SPMDs (fig. 10) were performed by using an Agilent 6890 GC (Agilent Technologies, Inc., Wilmington, Del.) coupled to a 5973N mass selective detector (Agilent Technologies, Inc., Palo Alto, Calif.). The separation was performed on a HP-5MS (30 m x $0.25 \mathrm{~mm}$ inner diameter $\mathrm{x} 0.25 \mu \mathrm{m}$ film thickness) capillary column (Agilent Technologies, Inc., Wilmington, Del.) with the temperature program of injection at $50^{\circ} \mathrm{C}$, held for $2 \mathrm{~min}$, ramped at $25^{\circ} \mathrm{C}$ per minute to $130^{\circ} \mathrm{C}$, held there for $1 \mathrm{~min}$, then ramped at $6^{\circ} \mathrm{C}$ per minute to $310^{\circ} \mathrm{C}$, and held there for $5 \mathrm{~min}$. Detector zone temperatures were set at $310^{\circ} \mathrm{C}$ for the mass selective detector transfer line, $150^{\circ} \mathrm{C}$ at the quadrupole, and $230^{\circ} \mathrm{C}$ at the source.

\section{Sex Steroid Hormones}

Individual adult western mosquitofish were placed in small glass tubes with 30 percent potassium hydroxide at three times the tissue volume, then boiled in a shaking water bath at $100^{\circ} \mathrm{C}$. Samples were vortexed for $1 \mathrm{~min}$, chilled on wet ice for $5 \mathrm{~min}$, and four aliquots of 50 microliters $(\mu \mathrm{L})$ each were placed in large glass tubes and frozen for later ether extraction. Samples were thawed, $4 \mathrm{~mL}$ of diethyl ether were added, and each tube was vortexed for $1 \mathrm{~min}$, then placed into a methanol/ dry ice bath. After 3-4 min, a white pellet precipitated, and the supernatant containing the sex steroid hormones was poured into another tube where diethyl ether was evaporated by using a vacuum while tubes were vortexed for $10-15 \mathrm{sec}$. This ether extraction was repeated to maximize the hormone extraction.

The androgen testosterone $(\mathrm{T})$ and estrogen (17ß-estradiol) (E2) were measured by radioimmunoassay by using competitive binding and monoclonal antibodies (Goodbred and others, 1997; McDonald and others, 2000; Noggle, 2005) (fig. 11). To two extract replicates of $50 \mu \mathrm{L}$ each, two radiolabeled hormones $\left(\left[2,3,6,7,16-{ }^{3} \mathrm{H}\right]\right.$-estradiol and $\left[1,2,6,7-{ }^{3} \mathrm{H}\right]$-testosterone) were added to the corresponding hormone-specific antibody and incubated overnight at $24^{\circ} \mathrm{C}$. During this time, the unlabeled hormone from the extract and the corresponding radiolabeled hormone competed for the same antibody binding sites. The nonantibody-bound, radio-labeled hormone was then removed from solution by addition of charcoal dextran followed by centrifugation. The remaining liquid sample containing the bound radio-labeled hormone was assayed with a scintillation spectrophotometer. Standard curves were developed for each hormone using known concentrations of $\mathrm{E} 2$ and $\mathrm{T}$, and $\mathrm{R}^{2}$ values between the actual and measured values were 0.93 and 0.88 , respectively. 


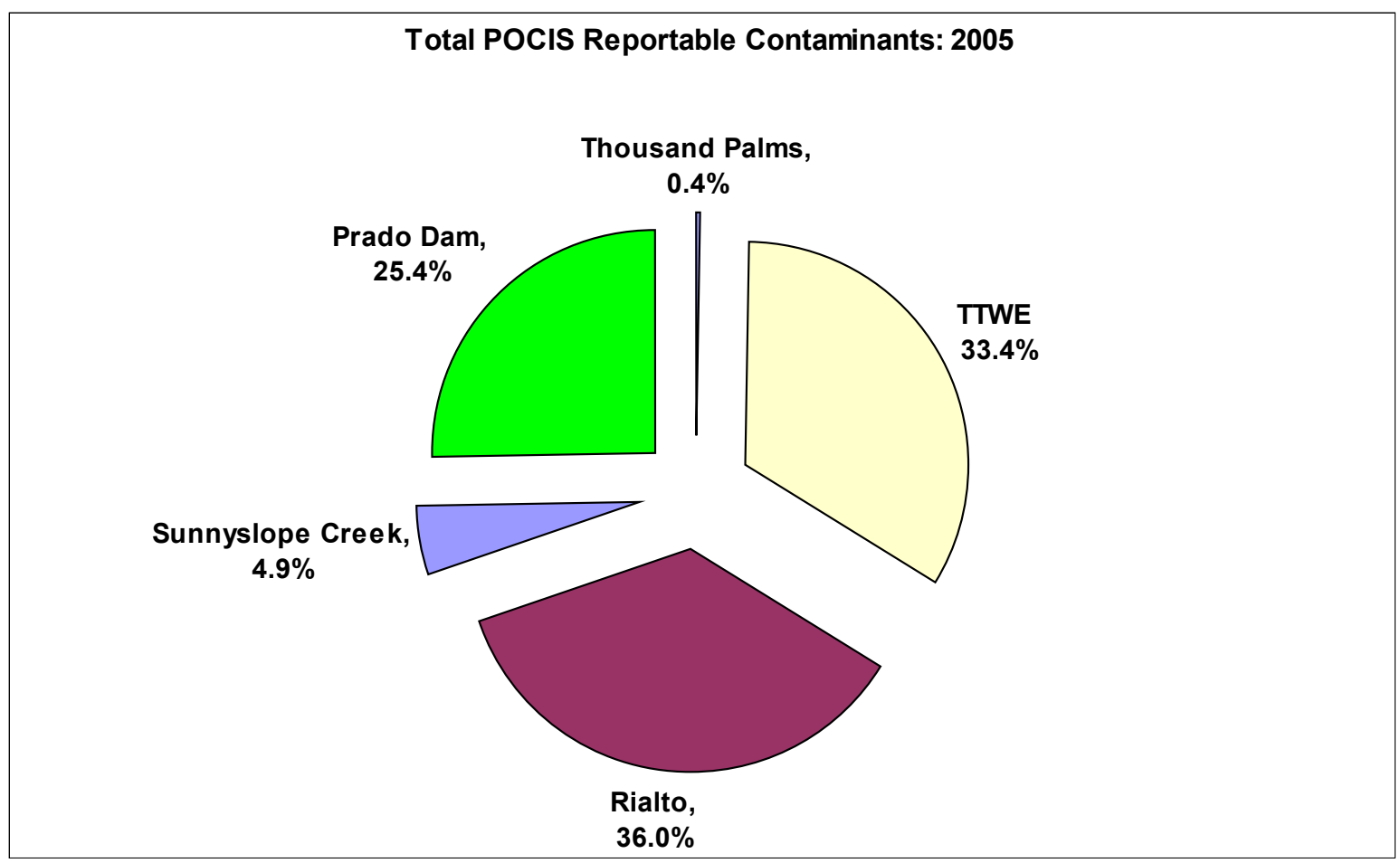

Figure 9. Percent of targeted organic wastewater contaminant concentrations from sites in the Santa Ana River, Calif., that were detected in fractions from extracts from polar organic chemical integrative samplers (POCIS) shown to have a response in an in vitro yeast estrogen screen assay. Sampling sites included a point source for tertiary treated wastewater effluents (TTWE).

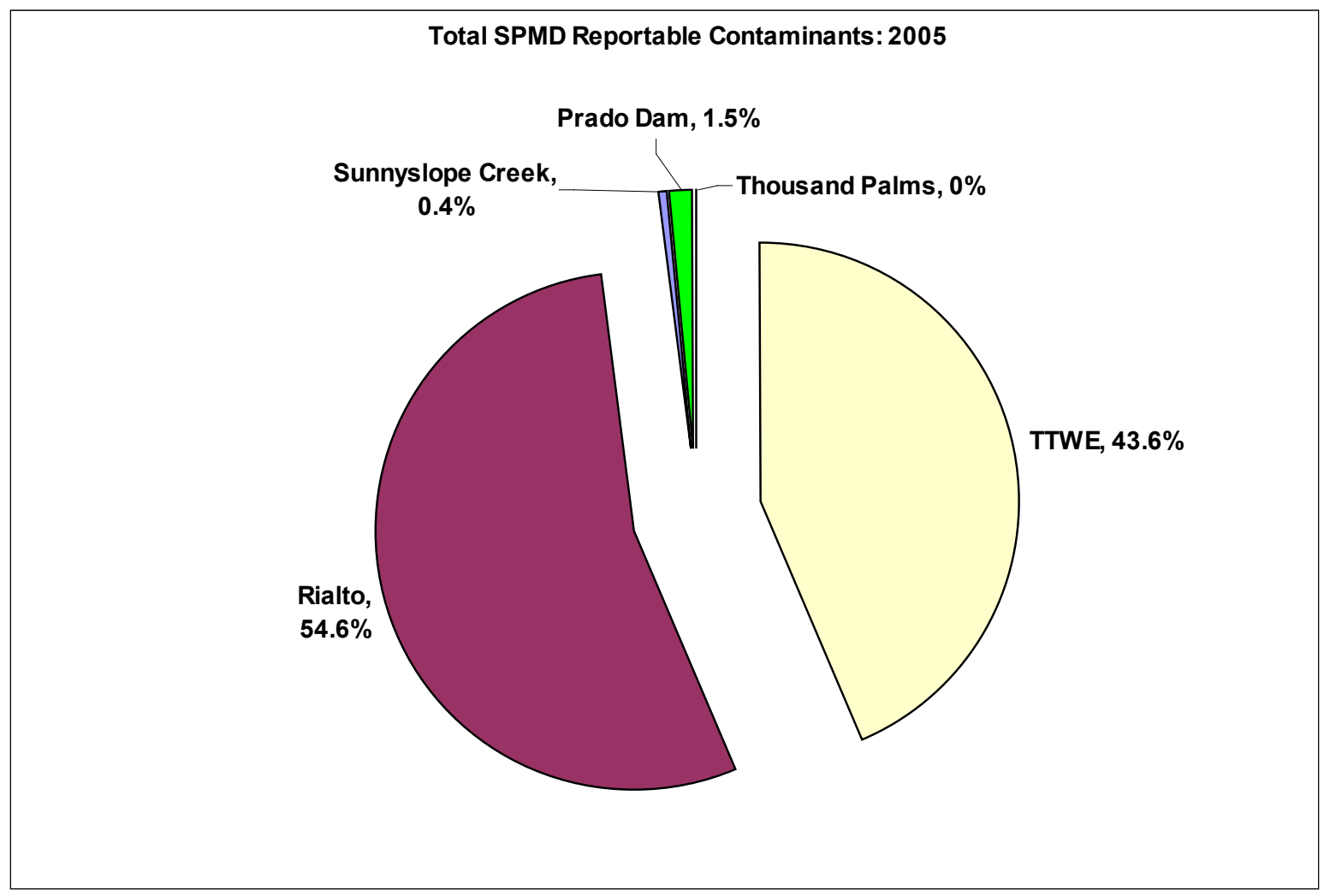

Figure 10. Percentages of contaminant concentrations that influence estrogenic function detected in semipermeable membrane devices from wastewater-related sites in the Santa Ana River, Calif. Targeted contaminants were among those that have been shown to influence estrogenic function. Contaminants were detected in fractions from semipermeable membrane devices (SPMD). Samples close to tertiary treated wastewater effluent (TTWE) were collected at a point source. 

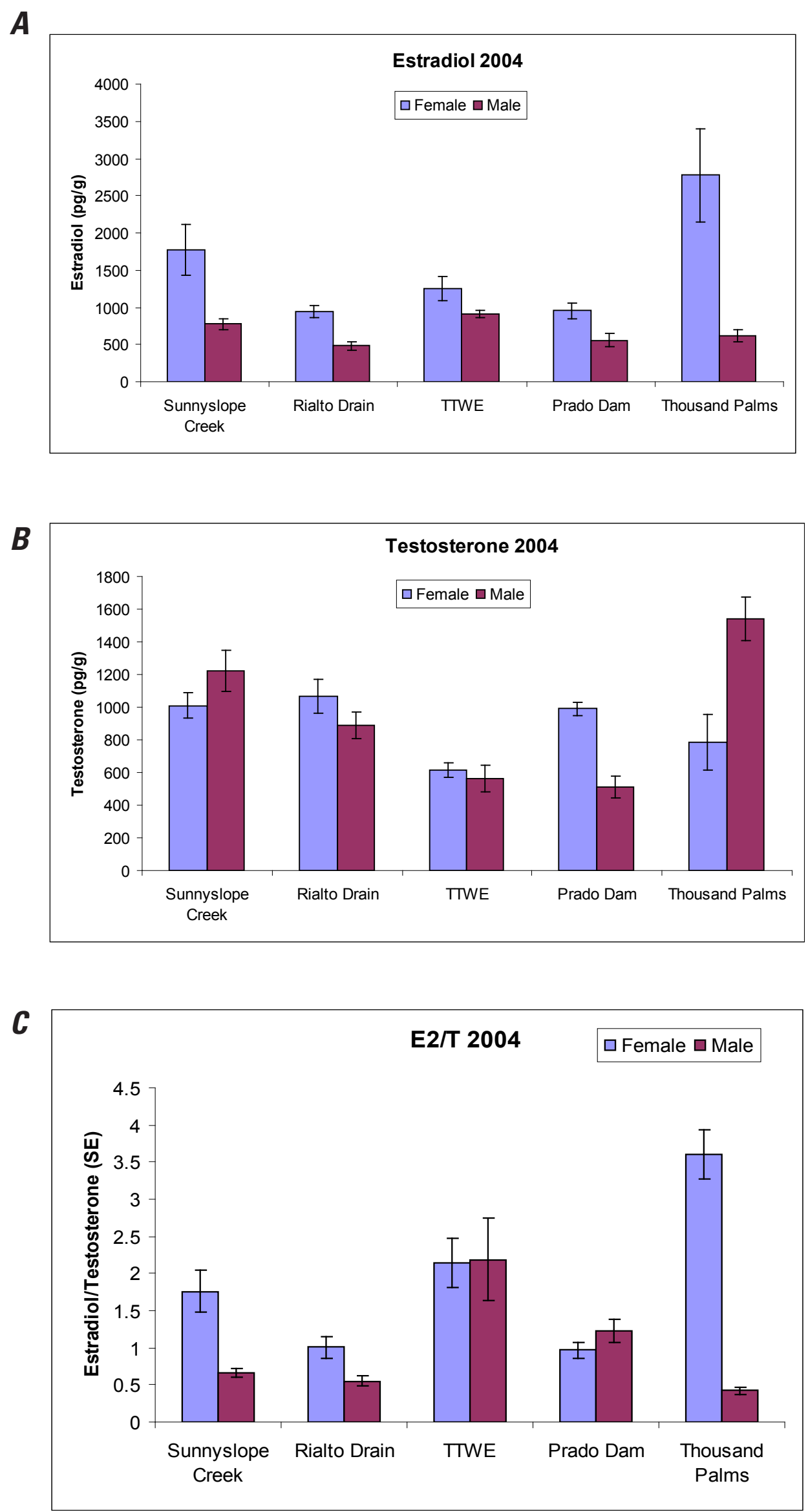

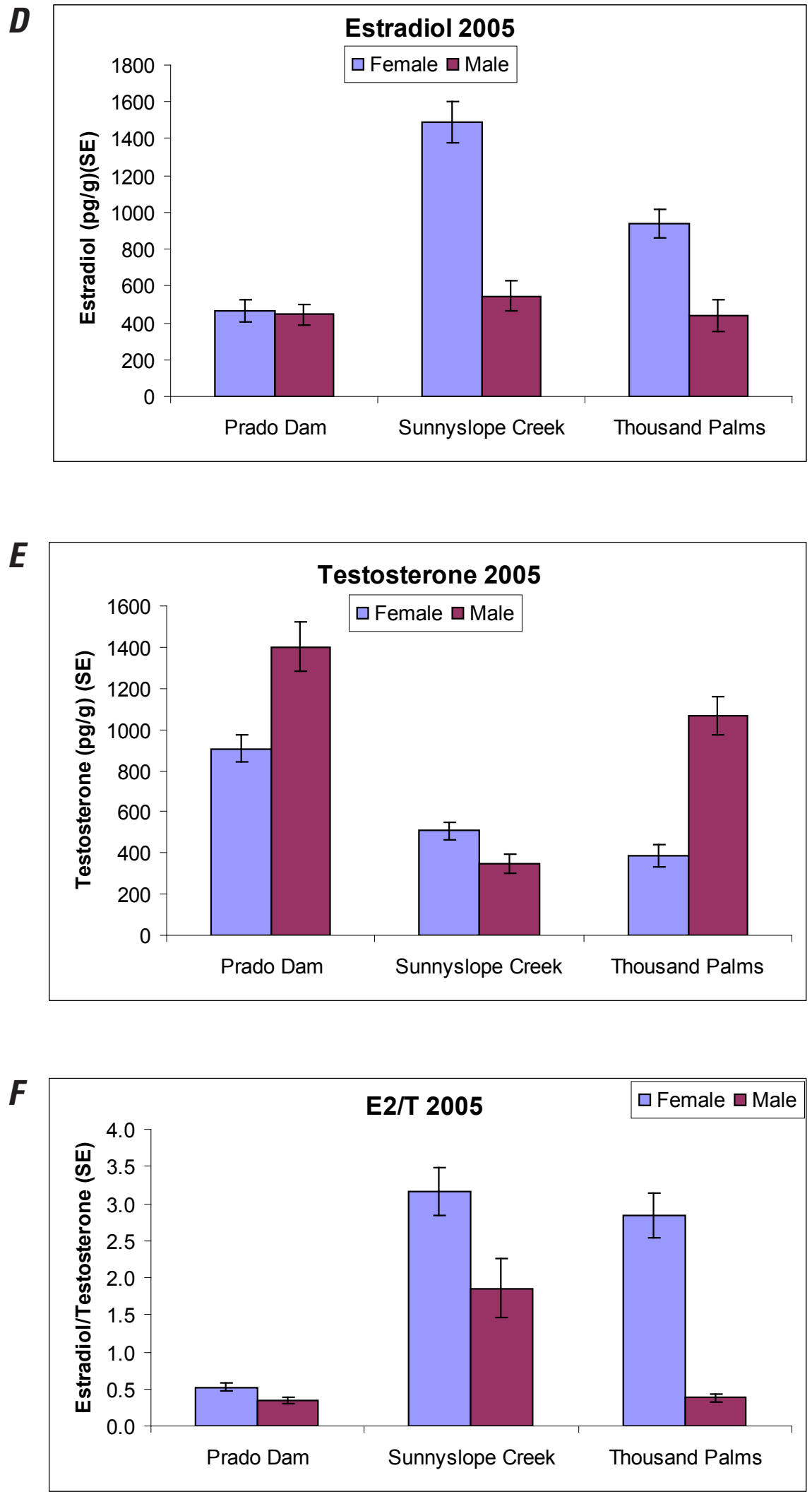

Figure 11. Levels of 17 $\beta$-estradiol $(E 2)(A, D)$, testosterone $(T)(B, E)$, and estradiol/testosterone ratios $(E T / T)(C, F)$ from western mosquitofish (Gambusia affinis) collected from the Santa Ana River, Calif., by site and year. Sampling sites included a point source for tertiary treated wastewater effluents (TTWE). Sample size equals 12 fish per bar (standard error bars are shown). 


\section{Secondary Sex Characteristics and Organosomatic Indices}

Using digital calipers, male mosquitofish TL and gonopodial lengths were measured at NWRC to the nearest 0.1 $\mathrm{mm}$. Fish were weighed to the nearest $0.001 \mathrm{~g}$. Gonopodia were removed with a scalpel and stored in individual microtubes in 10 percent buffered formalin until needed. Gonopodial lengths were also measured by using image analysis and measurement methods compared statistically (see below). Only data from males with recorded parameters of gonadal size, extractable sperm, or of $\mathrm{TL} \geq 20 \mathrm{~mm}$ (Feder and others, 1984) (for hormones) were used to ensure that only mature fish were analyzed.

Gonopodia were immersed in Coomassie blue dye for 1 sec and then placed on a microscope slide. Any excess muscle tissue at the base of the gonopodium was removed with a scalpel. Approximately $50-100 \mu \mathrm{L}$ of Immu-mount fixative (Thermo, Pittsburgh, Pa.) was applied to the center of the slide and carefully spread to form a thin layer with few bubbles. With the aid of a dissecting microscope, the gonopodia were moved toward the center of the fixative and manipulated by using blunt needles until the rays of the fin were spread out evenly. A cover slip was added and the slide preparation dried for at least $24 \mathrm{~h}$. Measurements of gonopodial lengths were made with an Olympus BX51 light microscope (Olympus America, Center Valley, Pa.) along with a DP71 digital camera (Olympus) and Image J software (http://rsb.info.nih.gov/ ij/). After microscope objective calibration and magnification bar generation, images were taken at $12.5-100 x$ total magnification. Measurements were made of entire gonopodial lengths (figs. 12-13), lengths of rays 4 (R4) and 6 (R6), and widths of the sixth segment (S6) of R4 and the third fin ray (R3) (figs. 14-23). Because R4 elongates as the gonopodium forms, whereas R6 does not, the ratio (R4:R6) is an index of elongation. Because new bone is added to R3 during gonopodial development causing it to become thicker than the other rays, the width ratio (R3S6:R4S6) provides an estimate of gonopodial thickening.

Based on the presence and abundance of hooks and serrae near the gonopodial tip, a coded hook score was devised. A score of 4 was assigned when three or more hooks were present, generally with one ventral pair and one pair dorsal and with five or more internal serrae on the fourth ray. A score of 3 indicated that two hooks were present and five or more serrae were on the fourth fin ray. A score of 2 was assigned if one or two hooks were present, and there were fewer than five serrae. A score of 1 was assigned if there were zero hooks.

Sample IDs were randomized across sites; therefore, data were analyzed blindly to prevent bias.

Fish were dissected with microtools by using a dissecting microscope, liver and testes were extracted and weighed, and the condition and colors of organs were noted. Indices included gonopodial index (GI) (gonopodium length/total body length X 100), gonadosomatic index (GSI) (gonad weight/body weight * 100), and hepatosomatic index (HSI) (liver weight/body weight $* 100$ ).

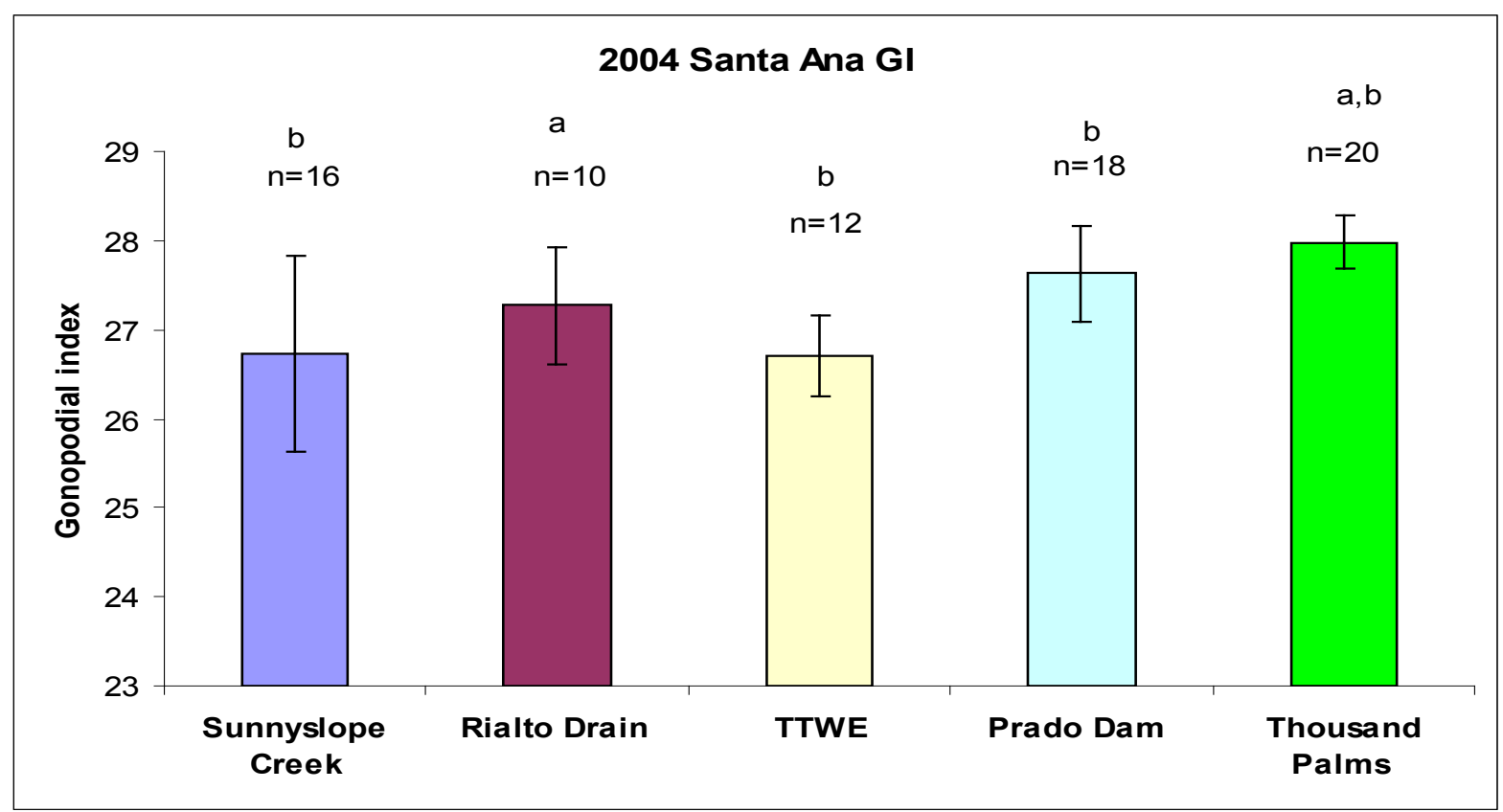

Figure 12. Gonopodial index (GI) values (gonopodium length divided by total fish length $x$ 100) (standard error bars) for samples of western mosquitofish (Gambusia affinis) collected from the Santa Ana River, Calif., in 2004. Sample sizes (n) are provided per sampling location; note that the Prado Dam collection site was below the dam; samples close to tertiary treated wastewater effluent (TTWE) were collected at a point source. By one-way analysis of variance with nontransformed data, site differences were significant at $P=0.0303$; differences are noted by letters above bars. 


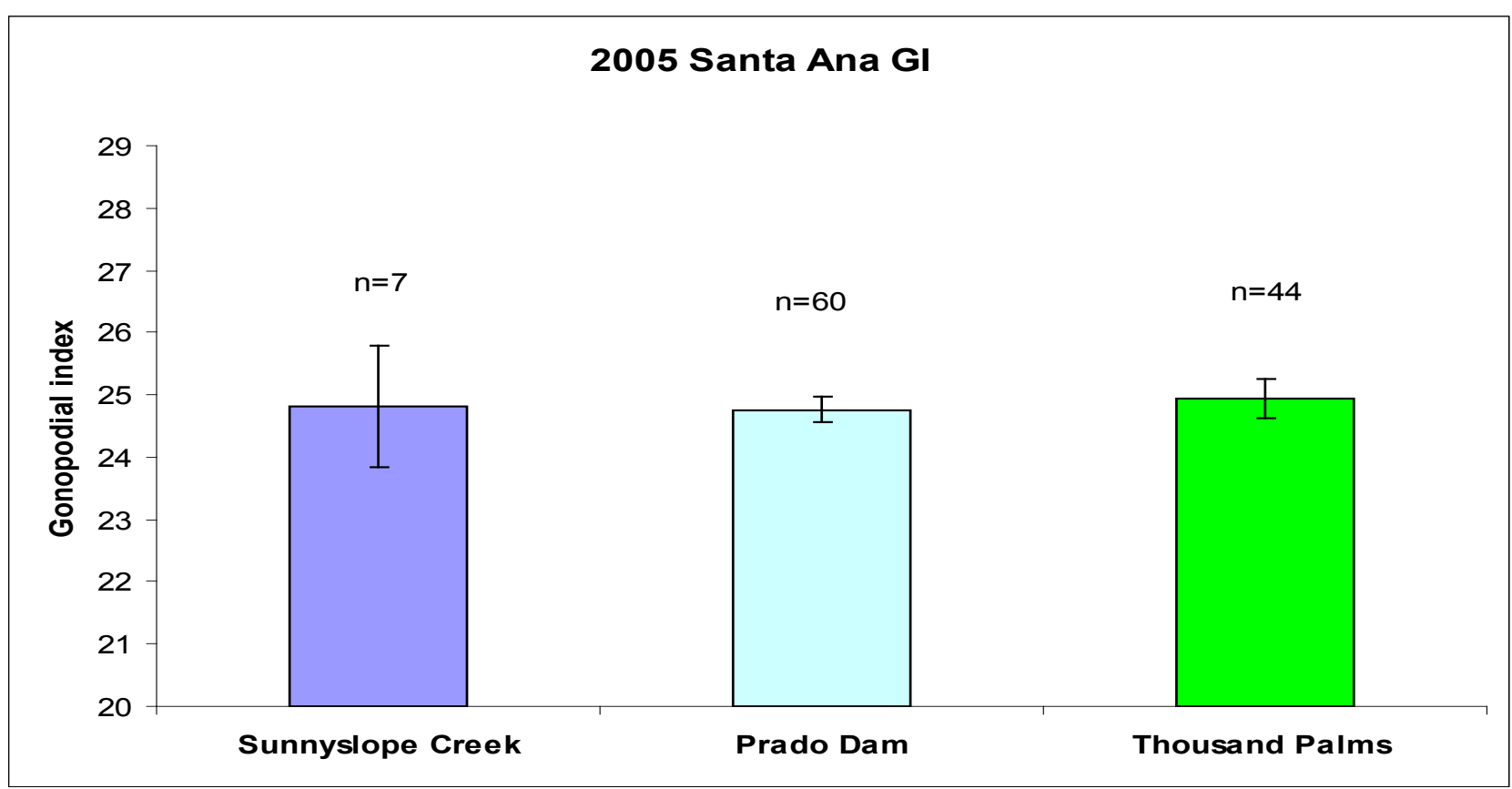

Figure 13. Gonopodial index (GI) values (gonopodium length divided by total fish length $x$ 100) (standard error bars) for samples of western mosquitofish (Gambusia affinis) collected from the Santa Ana River, Calif., in 2005. Sample sizes (n) are provided per sampling location. The Prado Dam collection site was within the wetlands above the dam. No significant differences among sites were noted.

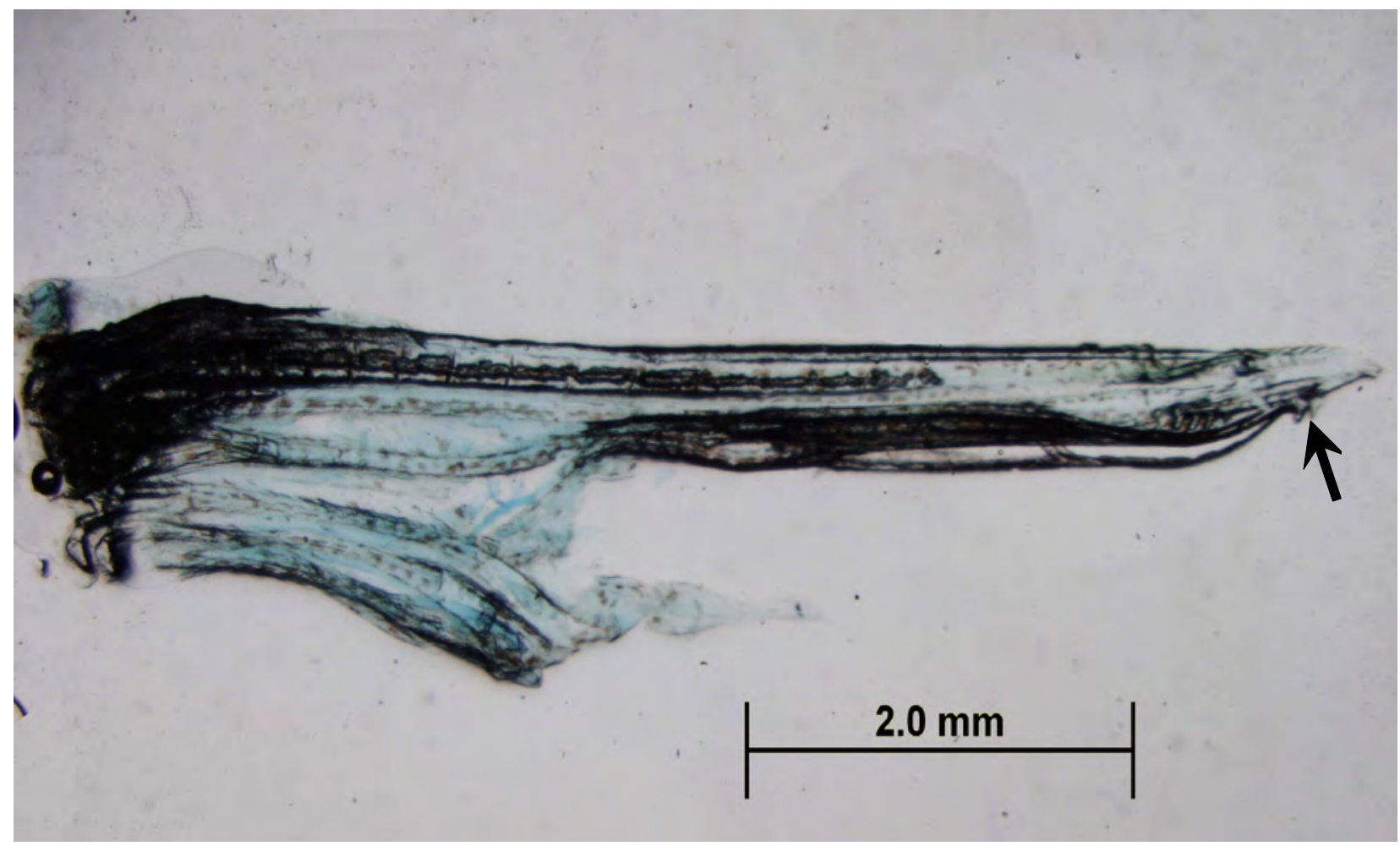

Figure 14. Typical, fully developed mature male gonopodium in western mosquitofish (Gambusia affinis) showing elongation and modification of anal fin with visible hooks (arrow). 


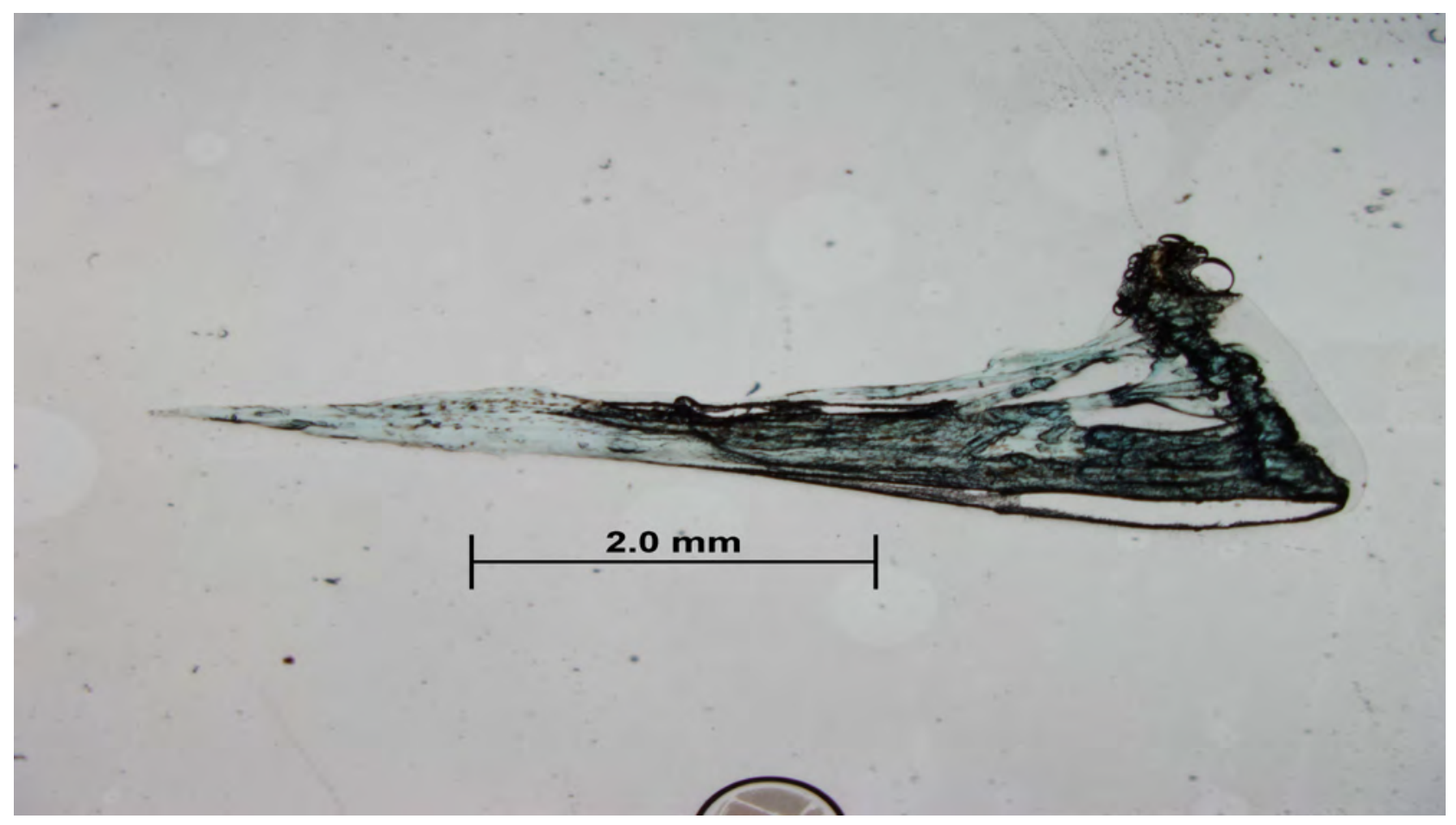

Figure 15. Underdeveloped male gonopodium from a western mosquitofish (Gambusia affinis) showing a small total length and elongation of anal fin without hook development.

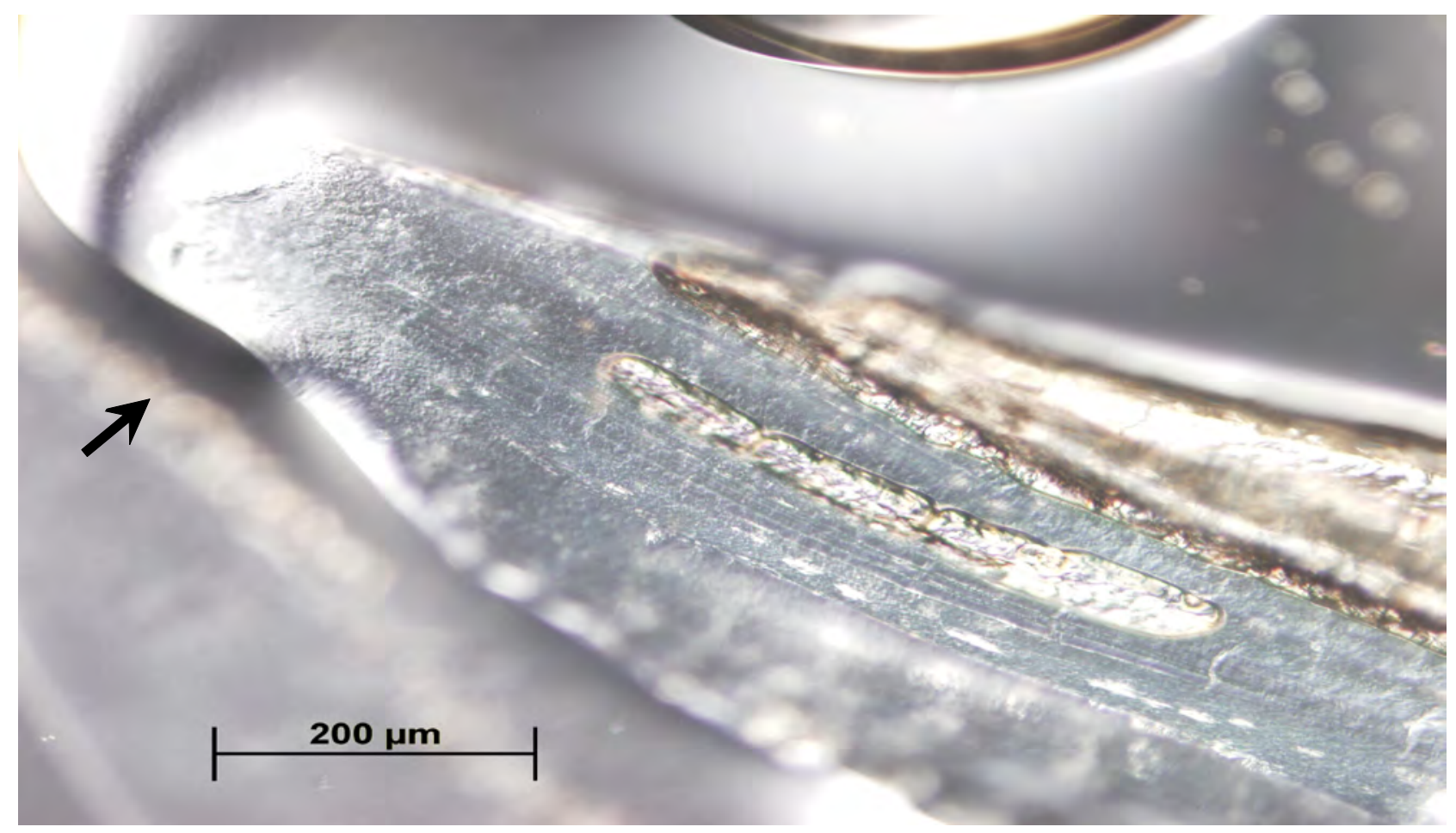

Figure 16. Hook score 1: No hooks on a gonopodium of a mature male western mosquitofish (Gambusia affinis). 


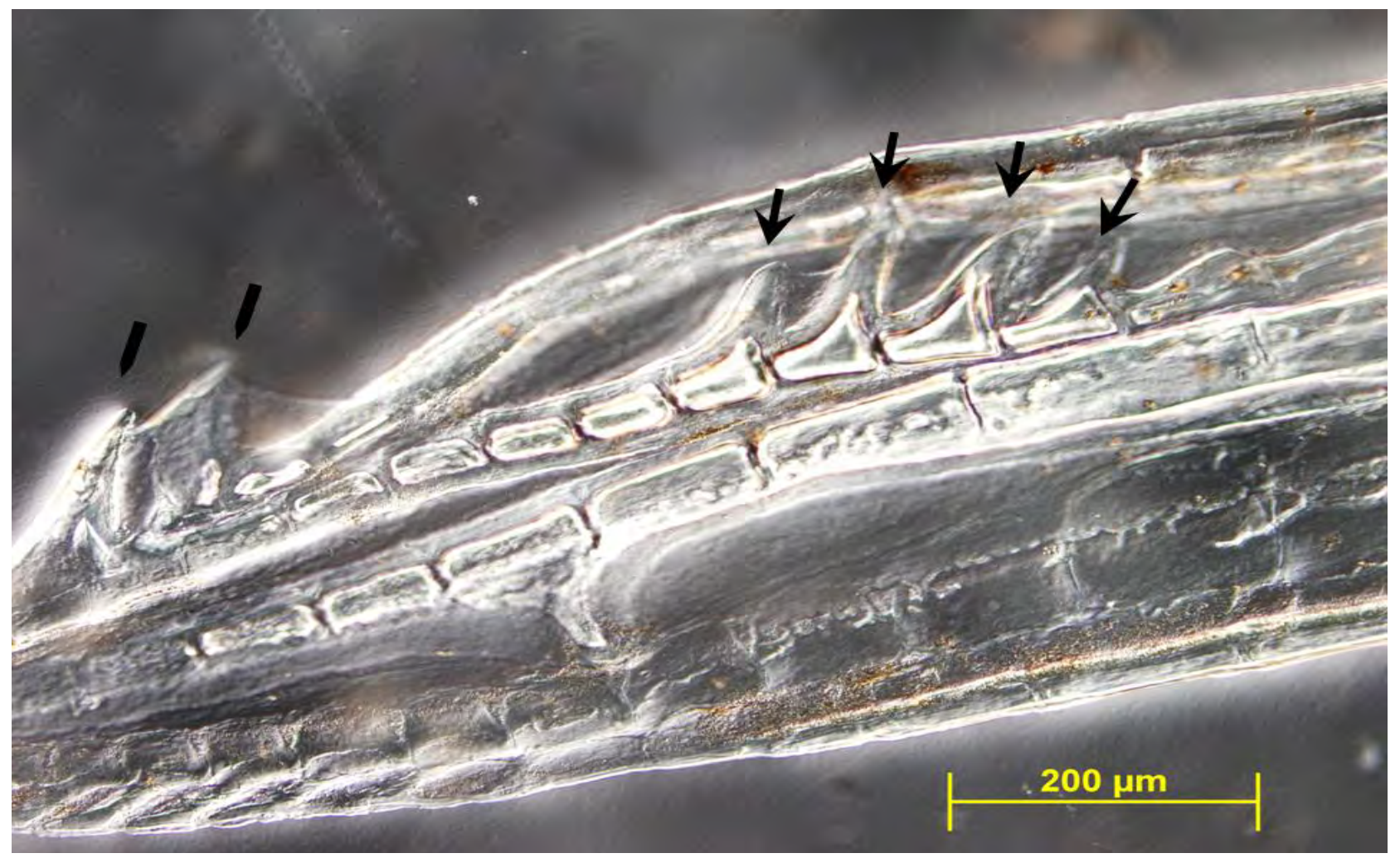

Figure 17. Hook score 2: No more than two hooks (arrowheads) are present, and there are fewer than 5 serrae (arrows) on fin ray 4 of the gonopodium of a mature western mosquitofish (Gambusia affinis).

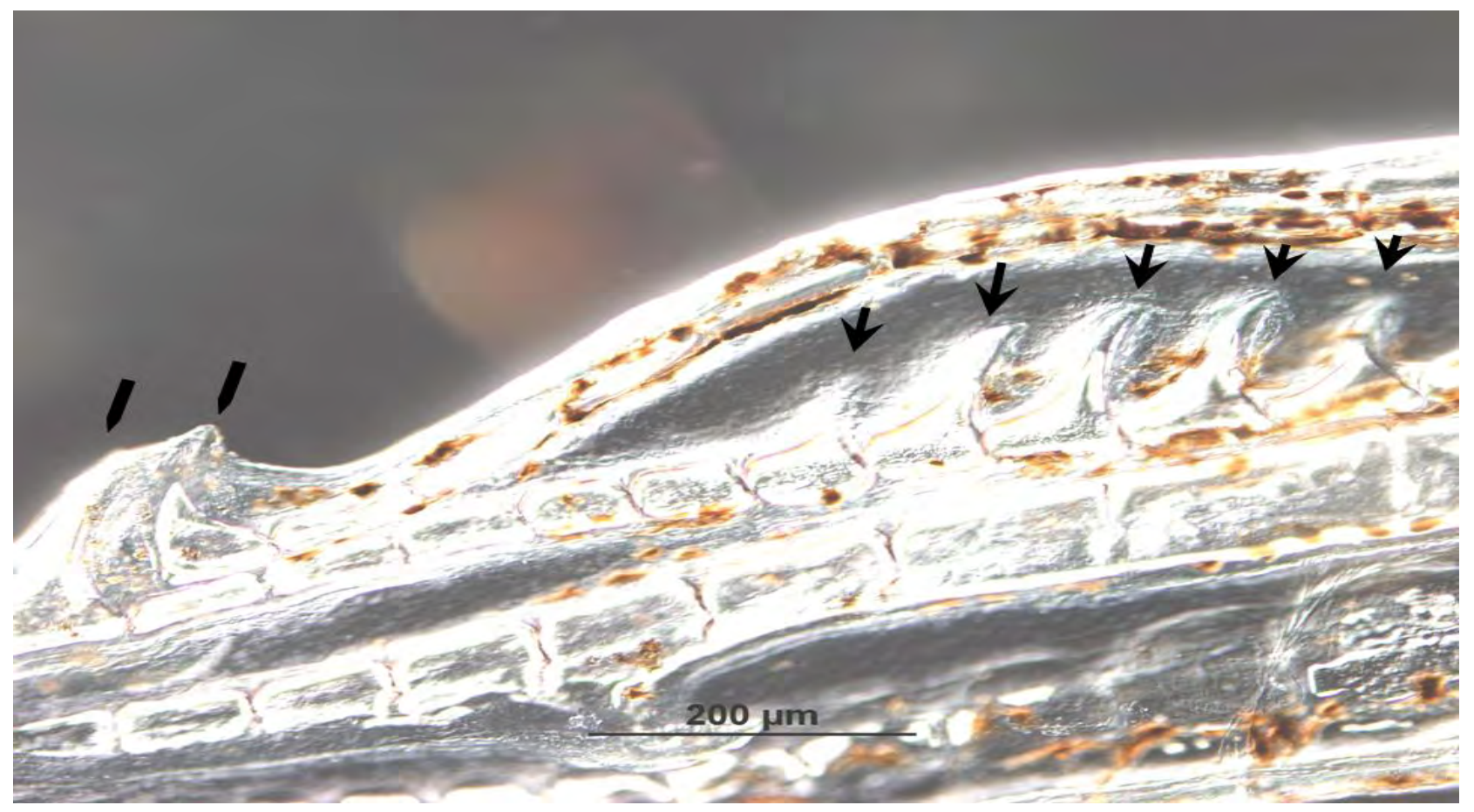

Figure 18. Hook score 3: Two hooks (arrowheads) are present, and there are five or more serrae (arrows) on fin ray 4 of the gonopodium of a mature western mosquitofish (Gambusia affinis). 


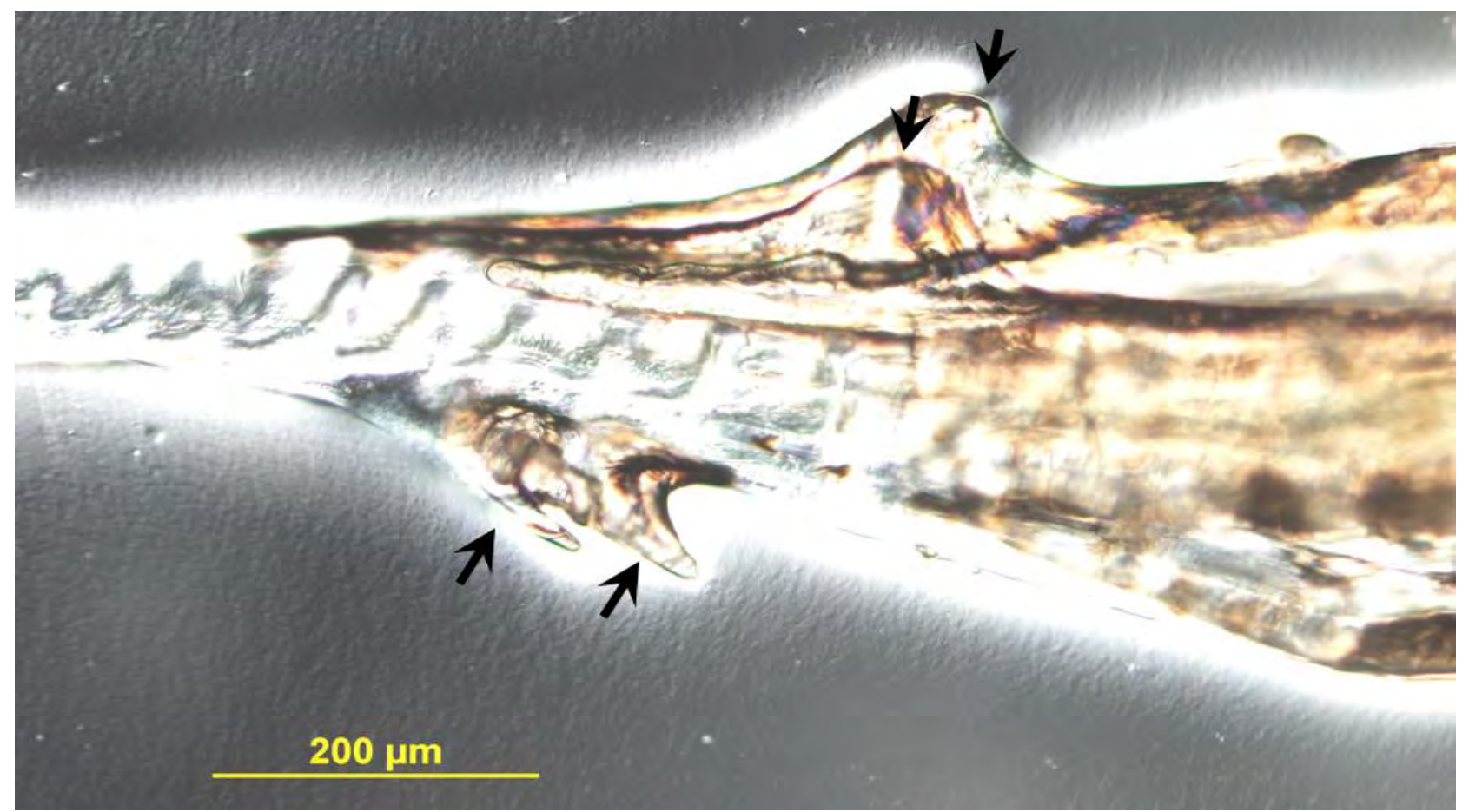

Figure 19. Hook score 4: three or more hooks (arrows) and five or more serrae (obscured) are present on the gonopodium of a mature western mosquitofish (Gambusia affinis).

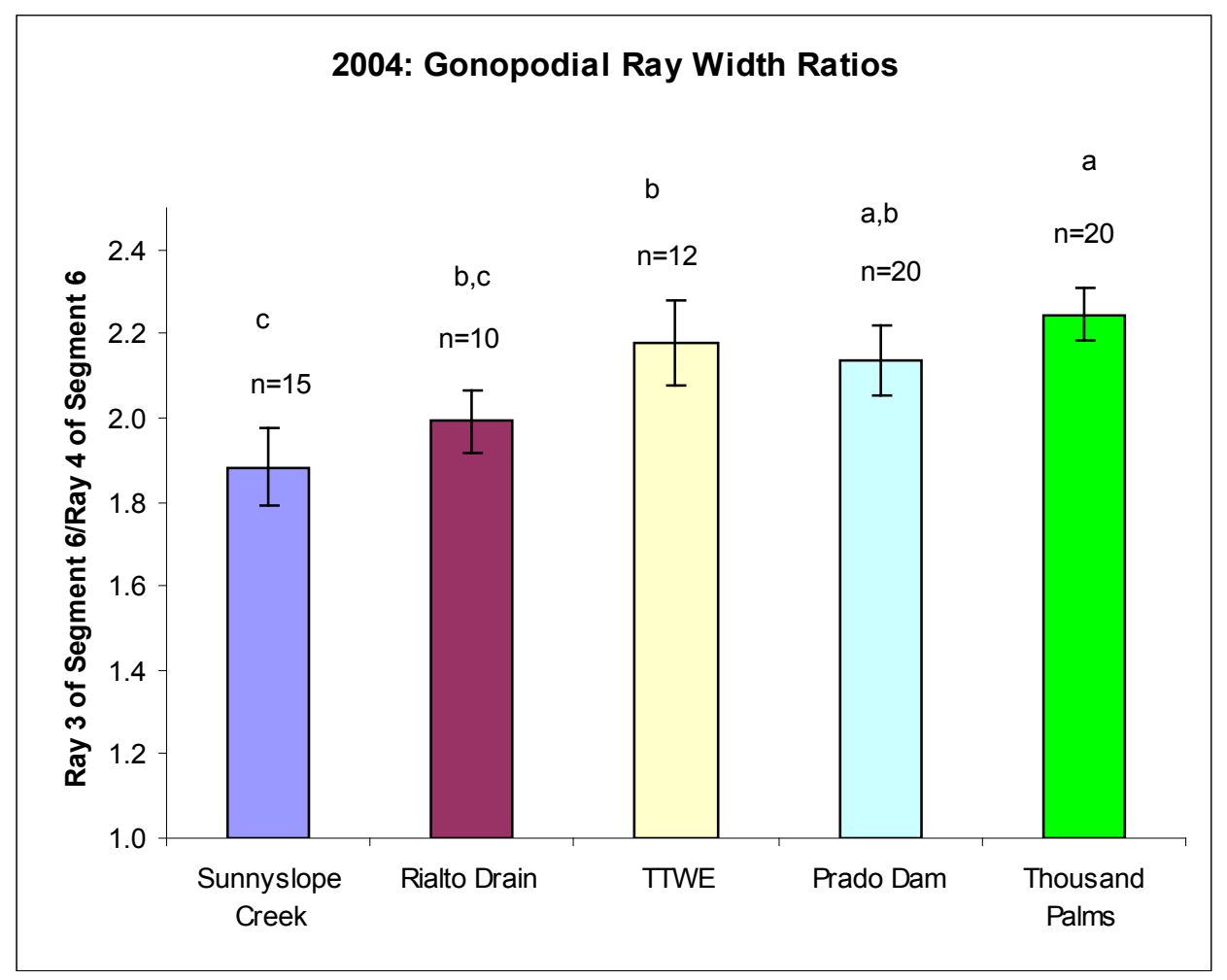

Figure 20. Ratio of anal fin ray segment 6 (S6) of rays 3 and 4 (R3 and R4) of western mosquitofish (Gambusia affinis) collected from the Santa Ana River, Calif. Fish were measured by using image analysis, and the ratio of thickening (see standard error bars) was plotted. Sample sizes $(\mathrm{n})$ are provided by sampling location; note that the Prado Dam collection site was below the dam; samples close to tertiary treated wastewater effluent (TTWE) were collected at a point source. By using the Wilcoxon and Kruskal-Wallis tests, site measurements were significantly different at $P=0.0379$, as noted by letters above bars. 


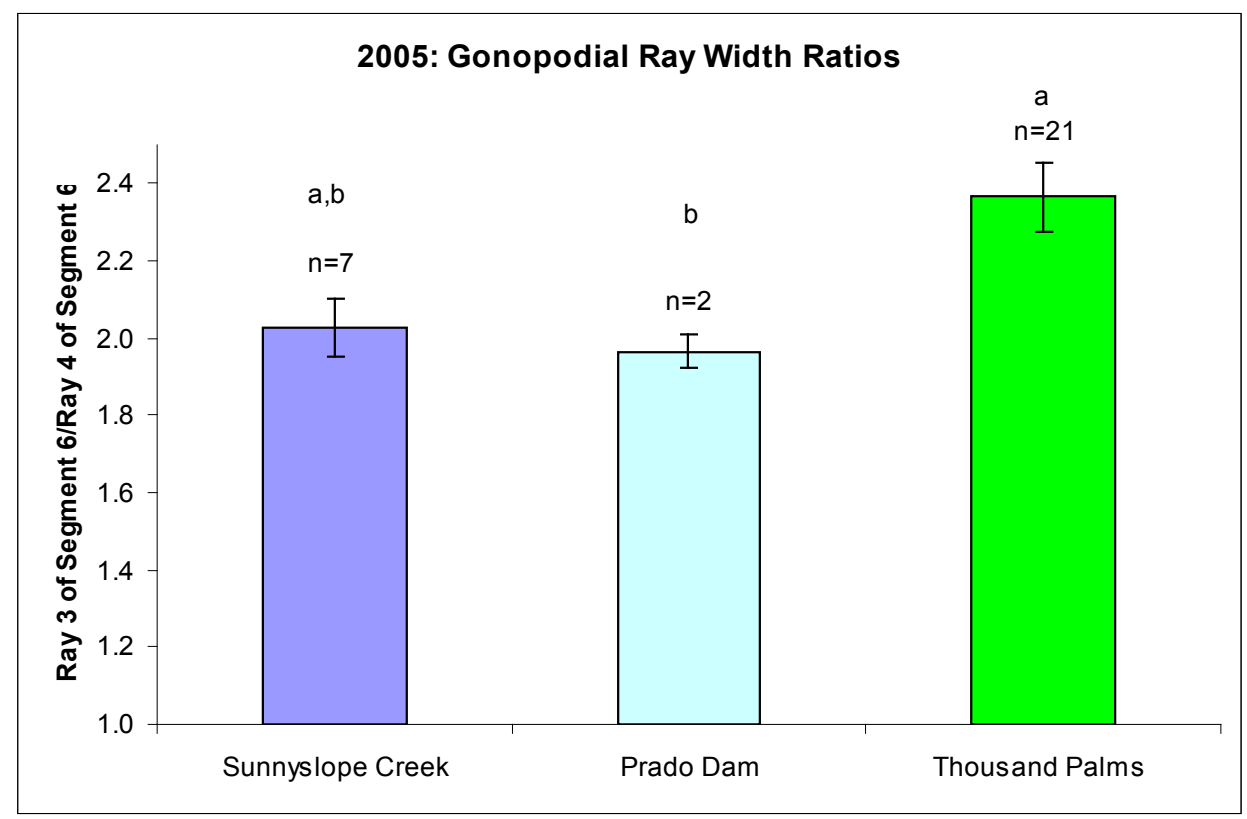

Figure 21. Ratio of anal fin ray segment 6 (S6) of rays 3 and 4 (R3 and R4) of western mosquitofish (Gambusia affinis) collected from the Santa Ana River, Calif. Fish were measured by using image analysis, and the ratio of thickening (see standard error bars) was plotted. Sample sizes (n) are provided by sampling location The Prado Dam collection site was within the dam. By Wilcoxon and Kruskal-Wallis tests, sites were significantly different at $P=0.0088$, as noted by letters above bars.

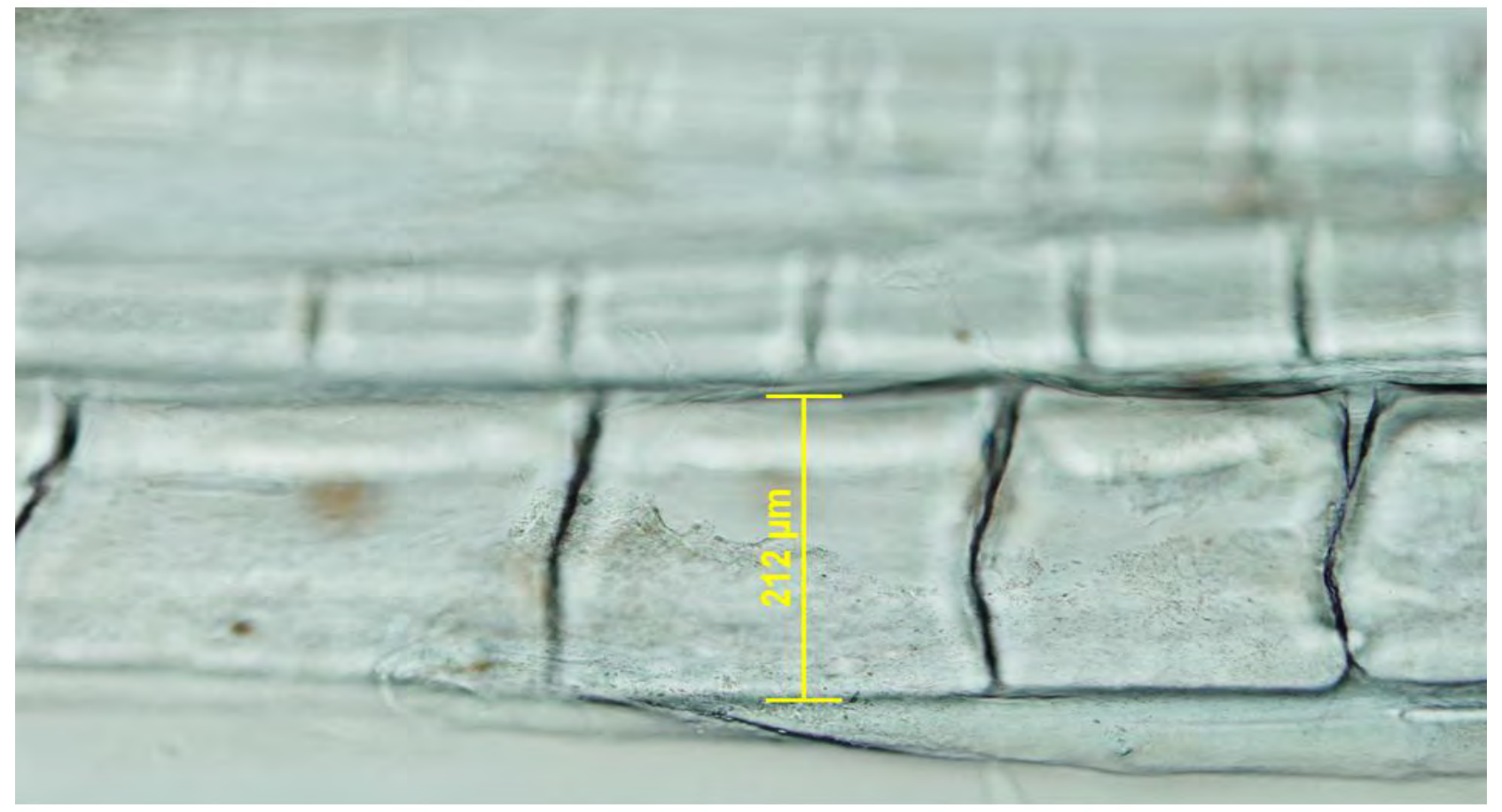

Figure 22. Measurement of width (microns) of segment 6 of ray 3 of a gonopodium from a male western mosquitofish (Gambusia affinis). 


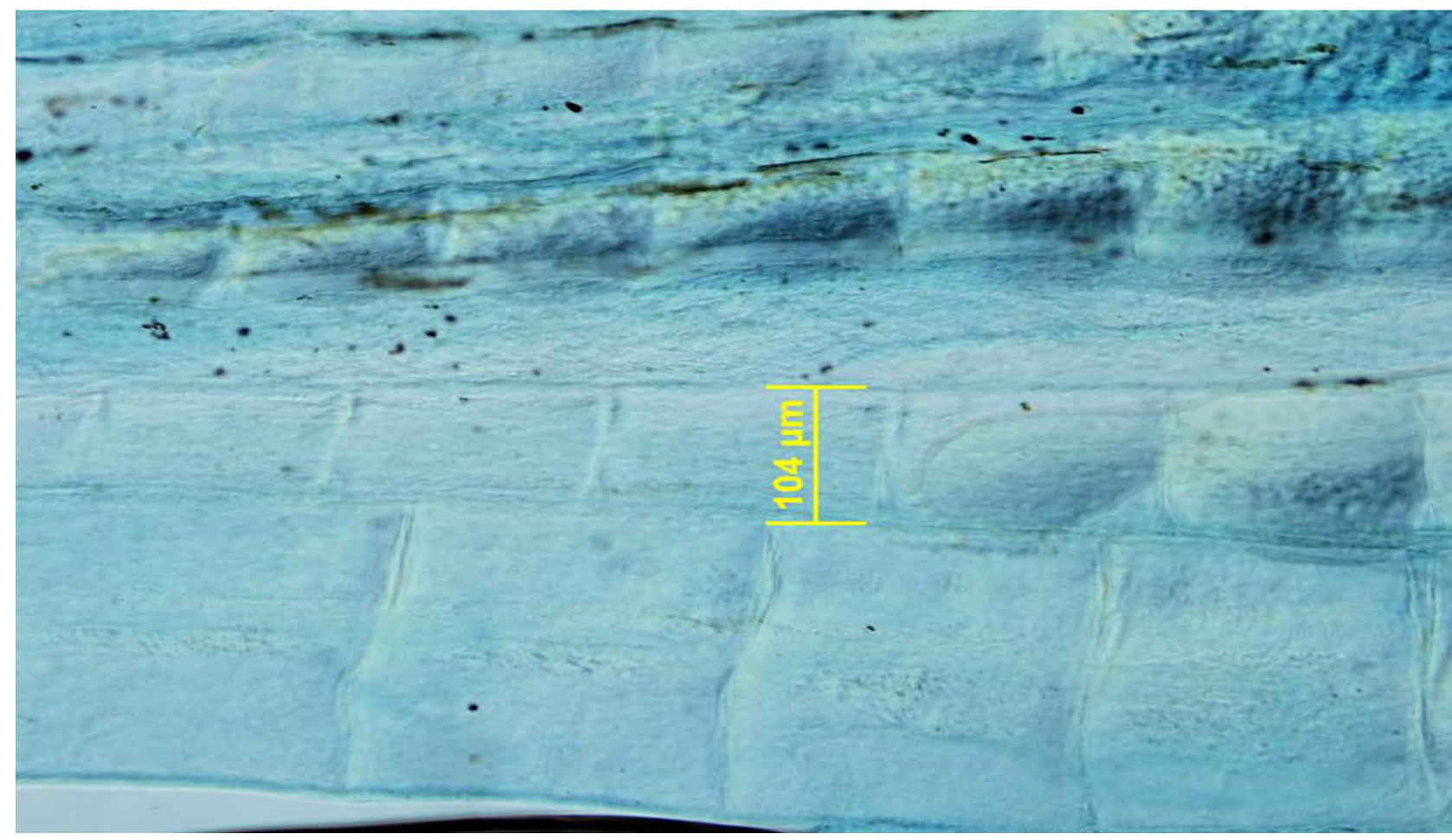

Figure 23. Measurement of width (microns) of segment 6 of ray 4 of a gonopodium from a male western mosquitofish (Gambusia affinis).

\section{Sperm Quality}

Live fish were euthanized by using tricaine methane sulfonate, morphological measures were made, and dissections were performed. The extracted testis was placed briefly in a humidified chamber until it was divided in two pieces, where one was used for motility, viability, and mitochondrial function measurements by using live cells, and the second was weighed for cell counts per milligram testis and for spermatogenic stage assessment by using fixed cells.

Sperm motility was scored by using darkfield microscopy at $100 \mathrm{X}$ magnification. An aliquot of $0.25 \mu \mathrm{L}$ sperm in modified Hanks' buffered salt solution at $\mathrm{pH} 7.4$ without calcium and $304 \mathrm{mOsm} / \mathrm{kg}$ (HBSS) (Glenn, 1998) was mixed with $25 \mu \mathrm{L}$ water for cell activation, and progressive movement of spermatozoa was estimated in duplicate to the nearest 5 percent by two separate readers.

After the unweighed testis were minced, suspensions were filtered through $30 \mu \mathrm{m}$ nylon mesh (Small Parts, Miami Lakes, Fla.) to yield individual cells, then diluted to $1 \mathrm{x}$ $10^{6} / \mathrm{mL}$ in HBSS. Cell membrane integrity (viability) and mitochondrial membrane potential were assessed by flow cytometry by using dual fluorescent staining techniques (Segovia and others, 2000; Jenkins and Goodbred, 2005). For viability analysis, the stains were SYBR-14 (Molecular Probes, Eugene, Oreg.) and propidium iodide (PI) (SigmaAldrich Chemical Company Co., St. Louis, Mo.). For measuring mitochondrial function, Rhodamine 123 (Molecular Probes) and PI (Sigma-Aldrich) were used.

For determining sperm counts, the weighed testis portion was placed in $100 \mu \mathrm{L}$ of $0.175 \mathrm{mM}$ potassium chloride (13.1 milligrams per liter [mg/L]) (Toft and others, 2003), minced for $1 \mathrm{~min}$, then maintained for $10 \mathrm{~min}$ in the potassium chloride, and $100 \mu \mathrm{L}$ buffered formalin was added prior to storage at $4{ }^{\circ} \mathrm{C}$. After thorough resuspension, aliquots were flow cytometrically counted by staining nucleic acids with a fluorescent dye in conjunction with a known concentration of microspheres (Bacteria Counting Kit [Molecular Probes]). This method was validated with western mosquitofish spermatozoa, where $\mathrm{R}^{2}$ was 0.9456 by using linear dilutions of spermatozoa. Up to $10 \mathrm{~K}$ events per sample in duplicate were collected by flow cytometry, and sperm count data were expressed as cells/milligram testis.

To assess spermatogenic stage (sexual maturity), buffered formalin-stored cells were diluted to $2 \times 10^{6} / \mathrm{mL}$, then stained with the nucleic acid dye PI (25 micrograms per milliliter $[\mu \mathrm{g} / \mathrm{mL}])$, ribonuclease A at $1 \mu \mathrm{g} / \mathrm{mL}$, and 0.1 percent Triton X-100 in sodium citrate (Sigma-Aldrich) for $30 \mathrm{~min}$ at $24^{\circ} \mathrm{C}$ in the dark (Crissman and Steinkamp, 1973). The distributions of nuclei in the haploid through tetraploid phases of spermatogenesis were assessed by flow cytometry (Jenkins and Goodbred, 2005). The percentage of the two most mature cell populations (spermatids and spermatozoa) were counted from a total of $5-10 \mathrm{~K}$ nuclei per sample in duplicate. 


\section{Statistical Analyses}

All statistical analyses were performed by using SAS (SAS Institute, Inc., 2003). Generally, for investigating differences in biomarker results, analyses of variance (ANOVAs) were run to examine differences among sites by using least square means for all pairwise site comparisons. Two sample t-tests were also run to compare data specifically from each contaminated site with the reference site. Data were either log or arcsin (square root) transformed appropriately. Data were analyzed by sex and per year with the level of significance at $\alpha=0.05$, and Bonferroni corrections used where applicable.

For sex hormones, preliminary analyses indicated nonsignificant correlations of $\mathrm{E} 2, \mathrm{~T}$, or $\mathrm{E} / \mathrm{T}$ with body weight; an analysis of covariance was run, but weight was not verified as a significant covariate. Therefore, ANOVAs were run on log-transformed sex hormone data.

Two different techniques (digital calipers and image analysis) for measuring gonopodial lengths were compared by using the paired t-test. Data were pooled from all sites in this study, and 2003 data from samples handled identically (Jenkins and Draugelis-Dale, 2006) were also included to enlarge the sample size. To determine GI values, dead fish TL measurements were included in the 2005 data set and a oneway ANOVA with pairwise comparisons (least square means) as well as two-sample t-tests for each contaminated site with reference site were performed (by using both log-transformed and nontransformed data). Nonparametric analyses (Wilcoxon and Kruskal-Wallis) were applied to the gonopodial elongation ratio (R4:R6) and width ratio (R3S6:R4S6).

Categorical analysis was employed with hook classifications, and PROC CATMOD and PROC FREQ (Chi
Square) were run. For 2005, hook scores from Prado Dam $(\mathrm{n}=2)$ were not included because of the small sample size $(\mathrm{n}=2)$. To meet model assumptions, the counts per site needed to be increased, whereby hook scores were grouped; scores 1 and 2 were delineated as "low," and scores 3 and 4 were delineated as "high."

Pearson product-moment correlations were determined for all 13 biomarkers, with 54 contaminants in the 2004 aquatic biota, 18 contaminants in the 2005 extracts from the POCIS, and 11 contaminants in the 2005 SPMDs, where $r$ determined the strength of the correlations. Because many correlations were weak, insignificant, or spurious (level of significance at $\alpha=0.10$ ), only one example is presented (testosterone with di (2-ethylhexyl) phthalate).

\section{Results and Discussion}

\section{Water Quality}

Water quality parameters were generally similar between sites and years; however, some variation was noted (table 1). Seasonally typical warm surface water for late spring in southern California occurred within the range of $20-29^{\circ} \mathrm{C}$ for all sites and both years. Western mosquitofish generally prefer warm water around $31^{\circ} \mathrm{C}$ and avoid temperatures below $20^{\circ} \mathrm{C}$ (Winkler, 1979). Specific conductance was the most variable parameter, ranging from a low of $773 \mu \mathrm{S} / \mathrm{cm}$ at Rialto Drain in 2004 to a high of $2,110 \mu \mathrm{S} / \mathrm{cm}$ at Thousand Palms in 2005 . Because mosquitofish tolerate high salinities, the highest value found (at about $1.2 \mathrm{ppt}$ ) was well below the upper tolerance

Table 1. Water quality parameters on sampling dates from field sites in the Santa Ana River, Calif., June 2004 and 2005.

$\left[{ }^{\circ} \mathrm{C}\right.$, degrees centigrade; $\mu \mathrm{S} / \mathrm{cm}$, microsiemens per centimeter; $\mathrm{mg} / \mathrm{L}$, milligrams per liter $]$

\begin{tabular}{|c|c|c|c|c|c|c|}
\hline Site & Date & Time & Temperature $\left({ }^{\circ} \mathrm{C}\right)$ & Specific Conductivity ( $\mu \mathrm{S} / \mathrm{cm})$ & $\mathrm{pH}$ & $\begin{array}{c}\text { Dissolved } \\
\text { Oxygen (mg/L) }\end{array}$ \\
\hline Rialto Drain & 8-Jun-04 & 1100 & 26.5 & 773 & 7.9 & 9.6 \\
\hline Prado Dam ${ }^{\mathrm{a}}$ & 10-Jun-04 & 830 & 20.0 & 1,020 & 8.0 & 9.3 \\
\hline Sunnyslope Creek & 7-Jun-04 & 1200 & 25.5 & 976 & 7.8 & 9.6 \\
\hline Thousand Palms & 7-Jun-04 & 530 & 29.0 & 1,896 & 8.0 & 6.5 \\
\hline TTWE $^{\mathrm{b}}$ & 7-Jun-05 & 630 & 22.8 & 815 & 6.9 & 6.1 \\
\hline Rialto Drain & 7-Jun-05 & 900 & 25.4 & 812 & 7.7 & 7 \\
\hline Prado Dam & 7-Jun-05 & 1200 & 21.6 & 855 & 7.4 & 7.6 \\
\hline Sunnyslope Creek & 6-Jun-05 & 1130 & 23.3 & 1,122 & 7.6 & 8.5 \\
\hline Thousand Palms & 6-Jun-05 & 800 & 21.4 & 2,110 & 7.2 & 5.1 \\
\hline
\end{tabular}

a The Prado Dam collection site was below the dam in 2004 and above the dam in 2005.

${ }^{\mathrm{b}}$ TTWE was a point source for tertiary treated wastewater effluent. 
of $55 \mathrm{ppt}$ (Moyle, 2002). In this study, $\mathrm{pH}$ values were within the normal range for natural waters (Hem, 1989) and varied only slightly (at about 15 percent) between sites and years ( $\mathrm{pH}$ 6.9-8.0). The range of dissolved oxygen (DO) was high $(5.1-9.6 \mathrm{mg} / \mathrm{L})$, partially because of the differences in daily sampling times and water temperatures. In productive streams where phytoplankton and periphyton are present, DO in early morning can be significantly lower compared to the late afternoon because algae produce oxygen during the day (Reid and Wood, 1976). Also, 100 percent saturation of DO is higher at lower water temperatures $\left(20^{\circ} \mathrm{C}\right.$ is $\left.9.4 \mathrm{mg} / \mathrm{L}\right)$, and lower at higher water temperatures $\left(29^{\circ} \mathrm{C}\right.$ is $\left.7.8 \mathrm{mg} / \mathrm{L}\right)$. In this study, the lowest DO, $5.1 \mathrm{mg} / \mathrm{L}$ (60 percent DO saturation), was measured early in the morning at Thousand Palms in 2005 , being below the warm water criteria of $5.5 \mathrm{mg} / \mathrm{L}$ of DO (U.S. Environmental Protection Agency, 1986). Under hypoxic conditions, very low DO levels $(\approx 1.0 \mathrm{mg} / \mathrm{L})$ can cause endocrine disruption in fish (Poon and others, 2002; Wu and others, 2003); however, all DO levels in this study were well above hypoxic levels. Overall, the differences and variations measured in water-quality parameters between sites and years were small and within the tolerance limits of western mosquitofish. Therefore, assessments of endocrine and reproductive biomarkers in western mosquitofish were likely not attributed to water-quality parameters but instead caused by other factors, such as exposure to environmental contaminants.

\section{Contaminants Analysis}

\section{Aquatic Biota}

Of the 59 OC environmental contaminants analyzed, a total of 25 were detected from aquatic biota sampled in the SAR (Table 2). These included several groups of compounds: chlordanes (insecticides); brominated diphenyl ethers (BDE; flame retardants), polychlorinated biphenyls (PCBs; industrial compounds); dichloro-diphenyl-trichloroethane (DDTs; insecticides); and four other compounds, hexachlorobenzene (fungicide), chlorthal (herbicide), octachlorostyrene (plastic component), and $p$-chloroaniline (a degradation product of pentachlorophenol, a wood preservative). The highest number of compounds (22) was detected at Prado Dam, followed by Rialto Drain (15), and Sunnyslope Creek (11); the lowest number (7) was found at TTWE and Thousand Palms.

Generally, concentrations were low ( $<10$ nanograms per gram

Table 2. Organochlorine compounds in aquatic biota composites (nanograms per gram wet weight) from the Santa Ana River and a reference site, 2004. Biota included mosquitofish (Gambusia affinis), tilapia (Tilapia zilli and Oreochromis mossambicus), and tadpoles of American bullfrog (Lithobates catesbeianus).

\begin{tabular}{|c|c|c|c|c|c|c|c|}
\hline \multirow[t]{2}{*}{ Contaminant $^{\mathrm{a}}$} & \multirow{2}{*}{$\begin{array}{c}\text { TTWE } \underline{\text { b }} \\
\text { mosquitofish }\end{array}$} & \multirow{2}{*}{$\begin{array}{l}\text { Sunnyslope } \\
\underline{\text { Creek }} \\
\text { mosquitofish }\end{array}$} & \multirow{2}{*}{$\begin{array}{l}\frac{\text { Thousand }}{\text { Palms }} \\
\text { mosquitofish }\end{array}$} & \multicolumn{3}{|c|}{ Rialto Drain } & \multirow{2}{*}{$\frac{\text { Prado Dam }}{\text { tadpole }}$} \\
\hline & & & & mosquitofish & tilapia & tadpole & \\
\hline Benfluralin & $<1$ & $<1$ & $<1$ & $<1$ & $<1$ & $<1$ & $<1$ \\
\hline alpha-HCH & $<1$ & $<1$ & $<1$ & $<1$ & $<1$ & $<1$ & $<1$ \\
\hline Galaxolide & $0.57 \mathrm{e}^{\mathrm{d}}$ & $<1$ & $<1$ & $0.26 \mathrm{e}$ & $0.21 \mathrm{e}$ & $0.22 \mathrm{e}$ & $0.28 \mathrm{e}$ \\
\hline gamma-HCH & $<1$ & $<1$ & $<1$ & $<1$ & $<1$ & $<1$ & $<1$ \\
\hline delta-HCH & $<1$ & $<1$ & $<1$ & $<1$ & $<1$ & $<1$ & $<1$ \\
\hline Aldrin & $<1$ & $<1$ & $<1$ & $<1$ & $<1$ & $<1$ & $<1$ \\
\hline Chlorpyrifos & $<1$ & $<1$ & $<1$ & $<1$ & $<1$ & $<1$ & $<1$ \\
\hline DCPA & $<1$ & 1.1 & $<1$ & $<1$ & $<1$ & $<1$ & 3 \\
\hline Fipronil & $<1$ & $<1$ & $<1$ & $<1$ & $<1$ & $<1$ & $<1$ \\
\hline trans-Chlordane & $<1$ & $<1$ & $<1$ & $<1$ & $<1$ & $<1$ & 1.7 \\
\hline$o, p '-D D E$ & $<1$ & $<1$ & $<1$ & $<1$ & $<1$ & $<1$ & $<1$ \\
\hline Endosulfan I & $<1$ & $<1$ & $<1$ & $<1$ & $<1$ & $<1$ & $<1$ \\
\hline cis-Chlordane & $<1$ & $<1$ & $<1$ & $<1$ & $<1$ & $<1$ & 2 \\
\hline trans-Nonachlor & $<1$ & 3.2 & $<1$ & $<1$ & 1.8 & $<1$ & 3.2 \\
\hline p,p'-DDE & $<20$ & $<20$ & 21 & $<20$ & $<20$ & $<20$ & 10 \\
\hline
\end{tabular}


Table 2. Organochlorine compounds in aquatic biota composites (nanograms per gram wet weight) from the Santa Ana River and a reference site, 2004. Biota included mosquitofish (Gambusia affinis), tilapia (Tilapia zilli and Oreochromis mossambicus), and tadpoles of American bullfrog (Lithobates catesbeianus). —Continued

\begin{tabular}{|c|c|c|c|c|c|c|c|}
\hline \multirow[t]{2}{*}{ Contaminant ${ }^{\mathrm{a}}$} & \multirow{2}{*}{$\begin{array}{c}\text { TTWE } \underline{b} \\
\text { mosquitofish }\end{array}$} & \multirow{2}{*}{$\begin{array}{l}\text { Sunnyslope } \\
\text { Creek } \\
\text { mosquitofish }\end{array}$} & \multirow{2}{*}{$\begin{array}{c}\frac{\text { Thousand }}{\text { Palms }} \\
\text { mosquitofish }\end{array}$} & \multicolumn{3}{|c|}{ Rialto Drain } & \multirow{2}{*}{$\frac{\text { Prado Dam }}{\text { tadpole }}$} \\
\hline & & & & mosquitofish & tilapia & tadpole & \\
\hline o,p'-DDD & $<50$ & $<50$ & $<50$ & $<50$ & $<50$ & $<50$ & $<50$ \\
\hline Endrin & $<1$ & $<1$ & $<1$ & $<1$ & $<1$ & $<1$ & $<1$ \\
\hline Endosulfan II & $<1$ & $<1$ & $<1$ & $<1$ & $<1$ & $<1$ & $<1$ \\
\hline o,p'-DDT & $<50$ & $<50$ & $<50$ & $<50$ & $<50$ & $<50$ & $<50$ \\
\hline cis-Nonachlor & $<1$ & 1.3 & $<1$ & $<1$ & $0.85 \mathrm{e}$ & $<1$ & 1.6 \\
\hline Endrin Aldehyde & $<1$ & $<1$ & $<1$ & $<1$ & $<1$ & $<1$ & $<1$ \\
\hline Endosulfan Sulfate & $<1$ & $<1$ & $<1$ & $<1$ & $<1$ & $<1$ & $<1$ \\
\hline p,p'-DDT & $<50$ & $<50$ & $<50$ & $<50$ & $<50$ & $<50$ & $<50$ \\
\hline Endrin Ketone & $<1$ & $<1$ & $<1$ & $<1$ & $<1$ & $<1$ & $<1$ \\
\hline PCB 1101 & $<1$ & $<1$ & $<1$ & $<1$ & $<1$ & $<1$ & $<1$ \\
\hline PCB 118 & $<1$ & $<1$ & $<1$ & $<1$ & $0.96 \mathrm{e}$ & $<1$ & $<1$ \\
\hline PCB 138 & $<1$ & 1.4 & $<1$ & $<1$ & 1.1 & $<1$ & 2.9 \\
\hline PCB 146 & $<1$ & $<1$ & $<1$ & $<1$ & $1.69 \mathrm{e}$ & $<1$ & $<1$ \\
\hline PCB 149 & $<1$ & $<1$ & $<1$ & $<1$ & $<1$ & $<1$ & $<1$ \\
\hline PCB 151 & $<1$ & $<1$ & $<1$ & $<1$ & $<1$ & $<1$ & $<1$ \\
\hline PCB 170 & $<1$ & $<1$ & $<1$ & $<1$ & 1.3 & $<1$ & 1.8 \\
\hline PCB 174 & $<1$ & $<1$ & $<1$ & $<1$ & $<1$ & $<1$ & 1.2 \\
\hline PCB 177 & $<1$ & $<1$ & $<1$ & $<1$ & $<1$ & $<1$ & 1.1 \\
\hline PCB 180 & $<1$ & 1.4 & 1.4 & 1.4 & 1.3 & 1.2 & 2.4 \\
\hline Toxaphene 4 & $<200$ & $<200$ & $<200$ & $<200$ & $<200$ & $<200$ & $<200$ \\
\hline Toxaphene 5 & $<200$ & $<200$ & $<200$ & $<200$ & $<200$ & $<200$ & $<200$ \\
\hline BDE 47 & 17 & 13 & 5.9 & 470 & 480 & 110 & 12 \\
\hline BDE 99 & 7.2 & 11 & 4 & 210 & 28 & 81 & 9.5 \\
\hline BDE 100 & 2.8 & 3 & 2.8 & 44 & 31 & 15 & 2.6 \\
\hline BDE 153 & 1.4 & 1.9 & 1.5 & 11 & 6.5 & 6 & 1.4 \\
\hline BDE 154 & 2 & 2.3 & 2.3 & 6.5 & 5.2 & 4.6 & 2.1 \\
\hline Sum BDE & 30 & 31 & 16 & 740 & 550 & 220 & 27 \\
\hline \multicolumn{8}{|c|}{ Surrogate Spikes (percent recovery) } \\
\hline Decafluorobiphenyl & 33 & 35 & 52 & 48 & 37 & 34 & 50 \\
\hline alpha-HCH-d ${ }_{6}$ & 83 & 81 & 80 & 75 & 82 & 70 & 80 \\
\hline p,p'-DDT-d 8 & 92 & 105 & 96 & 103 & 107 & 98 & 98 \\
\hline Nonachlorobiphenyl & 73 & 90 & 88 & 85 & 89 & 90 & 91 \\
\hline
\end{tabular}


$[\mathrm{ng} / \mathrm{g}])$, except for BDE, the sum of which was as high as 740 $\mathrm{ng} / \mathrm{g}$ at Rialto Drain. All five congeners of BDE were found in each sample at every site, including Thousand Palms. The sum concentration of all OC environmental contaminants in composite samples was highest at Rialto Drain (220-740 $\mathrm{ng} / \mathrm{g}$ ), then Prado Dam (65 ng/g), Sunnyslope Creek (40 ng/g), Thousand Palms (38 ng/g), and lowest at the TTWE point source $(32 \mathrm{ng} / \mathrm{g})$. Of the sum of OC at Thousand Palms, 55 percent was attributed to $p, p^{\prime}$-DDE. The composite samples at Rialto Drain were made from three animal species, and when ranked by species according to the numbers of compounds detected, results showed bullfrog tadpoles $<$ mosquitofish $<$ tilapia; when ranked by total OC concentrations, results showed bullfrog tadpoles $<$ tilapia $<$ mosquitofish. Both high and low matrix spikes for each analyte had acceptable recoveries (73-107 percent) for each composite except decafluorobiphenyl, where all recoveries were low.

Overall, the results of environmental contaminant analyses of aquatic biota from this study are similar to previous SAR studies (Rasmussen and Blethrow, 1991; Rasmussen, 1992; Saiki, 2000; and Burton, 2002), although concentrations of OCs have decreased over time. Of the 25 compounds detected in the SAR, only three pesticides (cisand trans-chlordane and $p, p^{\prime}$-DDE) and two flame retardants have been shown to interact with the endocrine system (Kojima and others, 2004) and can be considered EDCs. In addition to being a weak estrogen agonist, $p, p^{\prime}$-DDE is also an androgen antagonist (Kelce and others, 1995), so it can cause both feminization and demasculinization in fish. Although PCB congeners have not been shown to possess estrogenic activity, some of their hydroxylated metabolites have estrogenic activity (Nishihara and others, 2000). Many other modes of action are involved in endocrine disruption besides chemical binding to estrogen receptors. Therefore, the PCB congeners detected in SAR may have as yet unknown effects in fish, and concentrations needed to cause in vivo endocrine effects are not yet known. Moreover, endocrine receptors are present for nonsex steroidal hormones, such as thyroid hormones. The BDEs, widely used as flame retardants with similar chemical structures to the hydroxylated PCBs, are persistent and have environmental dispersions similar to PCBs and DDT. The BDE 47 and BDE 99 congeners dominate in human and environmental samples (Eriksson and others, 2001). The BDEs have been shown to affect thyroid hormone transport and metabolism, in addition to being weakly estrogenic (Legler and Brouwer, 2003). In this study, because thyroid biomarkers were not used, these types of endocrine effects on biota in the SAR are still unknown.

\section{Passive Samplers}

In the estrogenic fractions of POCIS extracts from SAR sites, 18 out of 59 targeted environmental OWC were detected from sampling sites (table 3; fig. 2). The highest number (16) came from the point source for TTWE, followed by 11 at Rialto Drain, and 9 at Prado Dam, with only 4 from
Sunnyslope Creek and 1 from the reference site, Thousand Palms. The highest cumulative concentration of targeted chemicals also came from the TTWE point source $(5.9 \mu \mathrm{g} /$ POCIS), followed by Rialto Drain (5.5 $\mu \mathrm{g}$ /POCIS), Prado Dam (3.9 $\mu \mathrm{g} / \mathrm{POCIS})$, then Sunnyslope Creek (0.8 $\mu \mathrm{g} / \mathrm{POCIS})$ (table 3; fig. 9). Most of these compounds are associated with treated sewage effluent, so the gradient of concentrations reflected proximity to WWTP effluents (fig. 2).

Measuring bioaccumulated environmental contaminants in fish tissue has certain advantages in assessing potential endocrine disruption, but results can be constrained by the analytical methods, such as varying detection limits, compound interferences, and the complex biometabolites. To address such shortcomings, this study deployed two types of passive samplers at each site in 2005 to sequester hydrophobic $\left(\log \mathrm{K}_{\mathrm{ow}}>3\right)$ and hydrophilic $\left(\log \mathrm{K}_{\mathrm{ow}}<3\right)$ environmental contaminants, and also included a TIE combined with the YES assay to test for potential of sampled chemicals to influence estrogenic function. These results reported in Alvarez and others (2007b) showed that, by far, the highest potential of fish being exposed to estrogenic compounds was at TTWE point source. A number of environmental contaminants were found in these hormonally active fractions of passive samplers at the TTWE point source that could have contributed to the estrogenicity, including: three fragrances (musk ketone, galaxolide [HHCB] and tonalide [AHTN]); two plasticizers (diethylphthalate and diethyl hexylphthalate); three surfactants ( $p$-tert-octylphenol, 4 nonylphenol, and 4 octylphenol); one component of sunscreen (homomethyl salicylate); and one component of soap (chloroxylenol). These compounds are emerging contaminants (Petrovic and others, 2004).

It is interesting to note that the fraction of passive sampling extract in which OC pesticides are sequestered (fraction 1) showed no estrogenicity in the TIE, thereby indicating other compounds are more important and of critical concern in causing endocrine disruption in this system. Although Saiki (2000) documented four weakly estrogenic pesticides in Santa Ana suckers from the SAR, the data from our study showed emerging contaminants from WWTPs as having higher potential at impacting endocrine systems. A life history of the Santa Ana sucker by Saiki and others (2007) documented marginally healthy populations in the SAR, where fish condition factors were lower compared to healthy populations in the San Gabriel River. In addition, Santa Ana suckers in the SAR rarely reached 2 years of age, but fish with this lifespan were much more common in the San Gabriel River. They concluded this might be caused by inadequate food resources, warmer water temperatures, or the presence of nonnative fish; however, exposure to EDCs from WWTPs is likely to be a contributing factor.

A study of emerging contaminants in the SAR by Gross and others (2004) found several of the same compounds, including the flame retardants (chlorinated tris-propylphosphates, TCPP) and surfactants (alkylphenols, AP) below WWTP discharge points. Their results showed significant decreases in concentrations of AP and TCPP 
Table 3. Targeted wastewater contaminants detected in estrogenic fractions from polar organic chemical integrative sampler (POCIS) extracts (micrograms per POCIS) from Santa Ana River and a reference site in 2005.

\begin{tabular}{|c|c|c|c|c|c|}
\hline Contaminant $^{\mathrm{a}}$ & TTWE $^{\mathrm{b}}$ & Rialto Drain & Prado Dam & Thousand Palms & Sunnyslope Creek \\
\hline N,N-diethyltoluamide (DEET) & 0.17 & 0.20 & 0.13 & $-c$ & - \\
\hline Diethyl phthalate & 0.38 & 0.37 & 0.38 & $0.06 \mathrm{e}^{\mathrm{d}}$ & 0.13 \\
\hline p-tert-Octylphenol & 0.26 & - & - & - & - \\
\hline Benzophenone & $0.02 \mathrm{e}$ & $0.03 \mathrm{e}$ & - & - & - \\
\hline Tributyl phosphate & 0.06 & $0.05 \mathrm{e}$ & 0.27 & - & - \\
\hline Ethyl citrate & - & $0.03 \mathrm{e}$ & - & - & - \\
\hline Prometon & - & - & $0.03 \mathrm{e}$ & - & - \\
\hline Phantolide (AHMI) & $0.02 \mathrm{e}$ & - & - & - & - \\
\hline 4-Octylphenol & 0.33 & - & - & - & - \\
\hline Tri(2-chloroethyl) phosphate & 0.36 & 0.72 & 0.36 & - & - \\
\hline Traseolide (ATII) & $0.05 \mathrm{e}$ & - & - & - & - \\
\hline Galaxolide (HHCB) & 0.74 & 1.3 & - & - & - \\
\hline Tonalide (AHTN) & 0.18 & 0.47 & - & - & - \\
\hline Tri(dichloroisopropyl) phosphate & 0.80 & 1.2 & 0.46 & - & - \\
\hline Tri(butoxyethyl) phosphate & 1.8 & - & 0.25 & - & $0.09 \mathrm{e}$ \\
\hline Triphenyl phosphate & $0.02 \mathrm{e}$ & - & - & - & - \\
\hline Di (2-ethylhexyl) phthalate (DEHP) & 0.39 & 1.0 & 1.7 & - & 0.32 \\
\hline Cholesterol & 0.41 & 0.27 & 0.35 & - & 0.30 \\
\hline Total Per Site & 5.9 & 5.53 & 3.9 & 0 & 0.75 \\
\hline
\end{tabular}

${ }^{a}$ Contaminant acronyms as International Union of Pure and Applied Chemistry (IUPAC) terms are provided in the alternative name table.

${ }^{\mathrm{b}}$ TTWE is a point source for tertiary treated wastewater effluent.

"A "-" indicated the chemical was below the method detection limit.

${ }^{\mathrm{d}}$ An "e" indicates an estimated value that was below the method reporting limit.

from the TTWE point source and Rialto Drain, compared to concentrations $11 \mathrm{~km}$ downstream at Prado Dam. In this report, data showed a similar trend for AP, but the reduction in TCPP was not as great. Another investigation of municipal wastewater effluents in Nevada (Osemwengie and Gerstenberger, 2004) detected these same two polycyclic musks - HHCB and AHTN — as found in the highest concentrations in this study from POCIS (table 3). Again, concentrations of HHCB and AHTN in that study were both tremendously reduced from the source at WWTP discharges, at $10 \mathrm{~km}$ downstream to Lake Mead. These trends in concentration reductions are similar to results in this study, where both of these compounds were detected at the TTWE point source and Rialto Drain, yet neither was found $11 \mathrm{~km}$ downstream at Prado Dam. Produced in the highest quantities of any fragrance by the industry (Herren and Berset, 2000),
AHTN and HHCB are the most likely polycyclic musks to be detected.

Polycyclic musks have been detected in fish tissue (Osemwengie and Gerstengerger 2004; Goodbred and others, 2007), whereby, in some situations, there is continuous aquatic exposure and these compounds are resistant to abiotic and biotic degradation. Because of chemical structures and physiochemical properties, polycyclic musks have the potential to bioaccumulate and bioconcentrate in adipose tissues of aquatic organisms (Daughton and Ternes, 1999). Although only one of the compounds detected from the estrogenic fractions from POCIS has been recognized as estrogenic (p-tert-octylphenol; Nishihara and others, 2000), additional estrogenic compounds and EDCs are probably present that were not measured or identified. 


\section{Semipermeable Membrane Devices}

Eleven out of 59 targeted compounds known to be associated with WWTP effluents were detected from the hormonally active portions of the SPMDs (table 4). The number of compounds detected at each study site are presented here in descending order: 10 were detected at the TTWE point source and Rialto Drain, 4 at Prado Dam, 2 at Sunnyslope Creek, and none at the reference site, Thousand Palms (fig. 10). The highest total concentration was from Rialto Drain (29.2 $\mu \mathrm{g} / \mathrm{SPMD})$, followed by the TTWE point source (23.4 $\mu \mathrm{g} / \mathrm{SPMD})$, then Prado Dam (0.8 $\mu \mathrm{g} / \mathrm{SPMD})$, and Sunnyslope Creek (0.2 $\mu \mathrm{g} / \mathrm{SPMD})$ (table 4$)$. These hydrophobic OWCs also followed a concentration gradient reflecting proximity to WWTP effluent (fig. 2). At Prado Dam, the polycyclic musk concentrations had essentially been eliminated. Their source was TTWE and Rialto Drain located $11 \mathrm{~km}$ upstream. By far, the highest concentration of OWCs was HHCB, shown to be anti-estrogenic in vitro and in vivo transgenic zebrafish (Pterois volitans) bioassays (Schreurs and others, 2005). Tonalide was found to be estrogenic and induced cellular proliferation (Bitsch and others, 2002). In a study by Seinen and others, 1999, these polycyclic musk fragrance compounds were assessed to have such weak estrogenic potency that estrogenic effects in wildlife species were not expected at levels of exposures tested. However, these chemicals are used in great volumes, and each can be used as a chemical marker for domestic wastewater contamination (Buerge and others, 2003).

Complex mixtures of OWCs and EDCs and their unknown modes of action, including nonmonotonic or biphasic response curves (Schmidt, 2001; Conolly and Lutz, 2004), make it difficult to predict potential effects on aquatic biota, including the Santa Ana sucker. However, aquatic organisms in the SAR are exposed to more of these compounds and at higher concentrations at the TTWE point source and Rialto Drain as shown by the chemical analyses of the POCIS and SPMD extracts. Rialto Drain is an important site supporting reproduction of the Santa Ana sucker, and the main stem of the SAR below the point source for TTWE and Rialto Drain is prime habitat for adult Santa Ana suckers (Haglund and others, 2001). Therefore, the Santa Ana sucker in these areas is exposed at different life stages to OWCs and EDCs.

\section{Sex Steroid Hormones}

Considerable ranges and variances in E2, T, and E2/T were measured from whole bodies of western mosquitofish in 2004 and 2005 (table 5). In both sexes, there was considerable

Table 4. Targeted wastewater-related contaminants ( $\mu \mathrm{g} / \mathrm{SPMD}$ ) detected in hormonally active fractions of sample extracts obtained from Santa Ana River sites, Calif., in 2005 by using semipermeable membrane devices.

\begin{tabular}{|c|c|c|c|c|c|}
\hline Contaminant $^{\mathrm{a}}$ & TTWE' & Rialto Drain & Prado Dam & Thousand Palms ${ }^{c}$ & Sunnyslope Creek \\
\hline Cashmeran (DPMI) & $-{ }^{d}$ & $0.08^{\mathrm{e}}$ & - & - & - \\
\hline Diethyl phthalate & 0.69 & 0.12 & $0.02 \mathrm{e}$ & - & 0.19 \\
\hline p-tert-Octylphenol & 0.21 & - & - & - & - \\
\hline Celestolide (ADBI) & 0.17 & $0.05 \mathrm{e}$ & - & - & - \\
\hline Galaxolide (HHCB) & 20 & 25 & 0.61 & - & - \\
\hline Tonalide (AHTN) & 1.3 & 3.1 & $0.07 \mathrm{e}$ & - & - \\
\hline Musk Ketone & $0.06 \mathrm{e}$ & $0.02 \mathrm{e}$ & - & - & - \\
\hline Di (2-ethylhexyl) phthalate (DEHP) & 0.43 & 0.25 & 0.18 & - & $0.07 \mathrm{e}$ \\
\hline
\end{tabular}

${ }^{a}$ Contaminant acronyms as International Union of Pure and Applied Chemistry (IUPAC) terms are provided in the alternative name table.

b TTWE is a point source for tertiary treated wastewater effluent.

${ }^{\mathrm{c}}$ No positive fractions from Thousand Palms were detected, therefore, no chemical analyses were performed.

d - indicates the chemical was below the method detection limit.

e An "e" indicates an estimated value that was below the method reporting limit. 
Table 5. Concentrations of $17 \beta$-estradiol (E2) and testosterone (T) (mean $\pm S E$ and range) and E2/T ratios from western mosquitofish (Gambusia affinis) collected from Santa Ana River sites, Calif.

\begin{tabular}{|c|c|c|c|c|c|c|}
\hline \multirow[b]{2}{*}{ Site } & \multicolumn{3}{|c|}{$\begin{array}{l}2004^{a} \\
\text { Male }\end{array}$} & \multicolumn{3}{|c|}{$\begin{array}{c}2004 \\
\text { Female }\end{array}$} \\
\hline & E2 (pg/g) & $T(p g / g)$ & $\mathrm{E} 2 / \mathrm{T}$ & E2 $(p g / g)$ & $T(p g / g)$ & $\mathrm{E} 2 / \mathrm{T}$ \\
\hline \multirow[t]{2}{*}{ Prado Dam } & $560 \pm 84.96$ & $510 \pm 68.69$ & $1.23 \pm 0.15$ & $955 \pm 104.31$ & $990 \pm 42.75$ & $0.97 \pm 0.10$ \\
\hline & $(180-1,020)$ & $(180-900)$ & $(0.20-1.86)$ & $(360-1,620)$ & $(660-1,200)$ & $(0.55-1.69)$ \\
\hline \multirow[t]{2}{*}{ Rialto Drain } & $480 \pm 63.96$ & $890 \pm 80.85$ & $0.55 \pm 0.07$ & $940 \pm 84.64$ & $1,065 \pm 103.69$ & $1.01 \pm 0.15$ \\
\hline & $(120-900)$ & $(240-1,260)$ & $(0.27-1.08)$ & $(540-1,500)$ & $(480-1,740)$ & $(0.41-2.09)$ \\
\hline \multirow[t]{2}{*}{ TTWE $^{\mathrm{b}}$} & $915 \pm 49.06$ & $565 \pm 83.38$ & $2.19 \pm 0.55$ & $1,255 \pm 165.22$ & $615 \pm 44.39$ & $2.14 \pm 0.33$ \\
\hline & $(720-1,260)$ & $(120-1,260)$ & $(1.00-8.00)$ & $(720-2,340)$ & $(360-900)$ & $(1.13-4.88)$ \\
\hline \multirow[t]{2}{*}{ Sunnyslope Creek } & $775 \pm 71.40$ & $1,220 \pm 124.54$ & $0.66 \pm 0.07$ & $1,775 \pm 339.69$ & $1,010 \pm 75.62$ & $1.76 \pm 0.28$ \\
\hline & $(300-1,080)$ & $(660-2,220)$ & $(0.42-1.27)$ & $(960-4,680)$ & $(600-1,440)$ & $(0.76-4.11)$ \\
\hline \multirow[t]{4}{*}{ Thousand Palms ${ }^{\mathrm{c}}$} & $620 \pm 80.68$ & $1,540 \pm 130.52$ & $0.42 \pm 0.05$ & $2,775 \pm 626.47$ & $785 \pm 172.80$ & $3.60 \pm 0.34$ \\
\hline & $(300-1,320)$ & $(600-2,220)$ & $(0.19-0.80)$ & $(1,260-7,200)$ & $(300-2,460)$ & $(2.00-5.71)$ \\
\hline & \multicolumn{3}{|c|}{2005} & \multicolumn{3}{|c|}{2005} \\
\hline & \multicolumn{3}{|c|}{ Male } & \multicolumn{3}{|c|}{ Female } \\
\hline \multirow[t]{2}{*}{ Prado Dam } & $447 \pm 56.10$ & $1400 \pm 120$ & $0.34 \pm 0.04$ & $467 \pm 58.95$ & $907 \pm 65.57$ & $0.52 \pm 0.05$ \\
\hline & $(160-800)$ & $(640-2,000)$ & $(0.09-0.63)$ & $(240-960)$ & $(400-1,200)$ & $(0.33-0.92)$ \\
\hline \multirow[t]{2}{*}{ Sunnyslope Creek } & $547 \pm 85.75$ & $347 \pm 46.54$ & $1.86 \pm 0.40$ & $1487 \pm 111.17$ & $507 \pm 45.48$ & $3.16 \pm 0.32$ \\
\hline & $(80-880)$ & $(160-720)$ & $(0.20-5.50)$ & $(1,040-2160)$ & $(240-720)$ & $(1.67-5.20)$ \\
\hline \multirow[t]{2}{*}{ Thousand Palms } & $440 \pm 88.9$ & $1067 \pm 95$ & $0.38 \pm 0.06$ & $940 \pm 75.08$ & $387 \pm 56.43$ & $2.84 \pm 0.30$ \\
\hline & $(80-1,040)$ & $(480-1,520)$ & $(0.11-0.81)$ & $(480-1,280)$ & $(160-720)$ & $(1.22-5.00)$ \\
\hline
\end{tabular}

range and variance in all hormones within site, between sites, and between years. For T, the largest ranges in males were seen at Sunnyslope Creek and Thousand Palms, and for females they were in Rialto Drain and Thousand Palms as were the largest variances. For E2, the largest range (5.7 X) and variance (SE of mean $\pm 626.47 \mathrm{pg} / \mathrm{g}$ ) was from females at Thousand Palms in 2004. Notably larger ranges in E2/T for males were at Sunnyslope Creek in 2005 (27.5) and at the point source for TTWE in 2004 (8X). For females, the E2/T ranges were considerably small at Prado Dam in 2004 and 2005, and in Rialto Dam in 2004.
Preliminary analyses indicated no significant correlations with E2, T, or E/T with body weight. ANOVA with log transformations was applied ( $P$ values are given). In spite of large ranges and high variances, there were significant differences in sex steroid hormones between sites. Ordered groupings from Duncan's multiple range tests are presented below and in figure 11. Abbreviations are "TP" for Thousand Palms, "SS" for Sunnyslope Creek, "WE" for the TTWE point source, "R" for Rialto Drain, and "P" for Prado Dam. 
For E2:

2004:

For females $(P<0.0001): \mathrm{TP} \geq \mathrm{SS} \geq \mathrm{WE} \geq \mathrm{R}=\mathrm{P}$

For males $(P=0.0009)$ : $\mathrm{WE} \geq \mathrm{SS} \geq \mathrm{TP} \geq \mathrm{P}=\mathrm{R}$. By

t-test, the only two sites showing a difference were

Thousand Palms and the TTWE point source, at $P=$ 0.0033 .

Similarly in 2005, there were significant differences in E2 levels with females:

For females $(P<0.0001)$ : $\mathrm{SS} \geq \mathrm{TP} \geq \mathrm{P}$

For males (NS) $(P=0.5719)$.

For T:

2004:

For females $(P=0.0006): \mathrm{R}=\mathrm{P}=\mathrm{SS}>\mathrm{TP}=\mathrm{WE}$

For males $(P<0.0001)$ : $\mathrm{TP} \geq \mathrm{SS} \geq \mathrm{R} \geq \mathrm{WE}=\mathrm{P}$

Similarly in 2005, there were significant differences in $\mathrm{T}$ levels with both sexes:

For females $(P<0.0001)$ : $\mathrm{P}>\mathrm{SS}>\mathrm{TP}$

For males $(P<0.0001)$ : $\mathrm{P}=\mathrm{TP}>\mathrm{SS}$

For E/T ratios:

2004:

For females $(P=0.0006)$ : $\mathrm{TP}>\mathrm{WE}=\mathrm{SS}>\mathrm{P}=\mathrm{R}$

For males $(P<0.0001)$ : $\mathrm{WE}>\mathrm{P}>\mathrm{SS} \geq \mathrm{R} \geq \mathrm{TP}$

Similarly in 2005, there were significant differences in E2/T

ratios with both sexes:

For females $(P<0.0001)$ : $\mathrm{SS}=\mathrm{TP}>\mathrm{P}$

For males $(P<0.0001)$ : $\mathrm{SS}>\mathrm{TP}=\mathrm{P}$

All fish have both E2 and T in their blood; however, the ratio of the two hormones varies between females and males, and this ratio is important because it influences sexual differentiation. The ratio of estrogens to androgens has been used as a screen for hormonal alterations because of exposure to EDCs in common carp (Cyprinus carpio) (Goodbred and others, 1997) and largemouth bass (Micropterus salmoides) (Sepulveda and others, 2002), where the male ratio is generally $<1.0$ and the female ratio is $>1.0$. Although natural variability occurs in hormone levels even during the same period of the reproductive cycle (Goodbred and others, 1997), significant differences in this ratio can indicate endocrine disruption. The highest ratios of E2/T among sites for females in both years of the study were generally shown at the sites least impacted by WWTP effluents-Thousand Palms and Sunnyslope Creek; the lowest ratios at Prado Dam and Rialto Drain were near the 1.0 male-like ratio. For males, it is interesting to note that at the TTWE point source, mean E2/T value was well above 1.0, and in fact was essentially equal to the female-like value. The mean E2/T values at Prado Dam were also above one and were higher than female-like values. For males in 2004, the ratio was lowest at Thousand Palms, and the highly impacted TTWE point source showed the highest ratio of E2/T (fig. 11C).

The highest E2 levels in males were shown at the source for TTWE in 2004 and may indicate some effect of exposure to EDCs, but there was no significant difference among sites in 2005. The highest $\mathrm{T}$ levels in males were shown at the reference site Thousand Palms in 2004 and at Prado Dam and Thousand Palms in 2005. The lowest T levels in males were shown at the TTWE source and Prado Dam in 2004, which may be caused by exposure to EDCs in WWTPs. Many studies have shown that fish exposed to EDCs have lower androgen levels, and androgens, including $\mathrm{T}$, are responsible for spermatogenesis (Toft and others, 2003). Reduced $\mathrm{T}$ in mosquitofish could contribute to lowered sperm counts (Toft and others, 2003) and reduced secondary sex characteristics (Doyle and Lim, 2002). At each of the effluent-impacted sites in 2004, the levels of $\mathrm{T}$ in females were higher than they were in males (fig. 11B), indicating exposure to EDC, some of which may have included compounds found in passive sampling extracts (tables 3 and 4). Together, these data show hormonal differences among sites, especially for 2004, when the relatively higher river flow allowed five sites to be sampled rather than only three in 2005 . These data strongly showed altered sex steroid hormone profiles in western mosquitofish at the most impacted sites, particularly males with reduced $\mathrm{T}$ and females with reduced $\mathrm{E}$.

\section{Secondary Sex Characteristics}

\section{Gonopodial Index (GI)}

Results of paired t-tests indicated no significant difference for the comparison of length measurement methods using digital calipers and image analysis $\left(\mathrm{t}_{(140)}=-1.091, P\right.$ $=0.2770$ ). Thus, the caliper method or the image analysis methods were equally preferable.

With regard to the analysis of the GI in male western mosquitofish in 2004, site was significant when using pairwise comparison (least squares means), where indices at Rialto Drain and Thousand Palms yielded the highest values ( $P$ $=0.0303$ ) (fig. 12). For 2005, there were no significant differences among the sites $(P=0.3897)$ (fig. 13) when using both of the primary statistical tests. Gonopodial development is a secondary sex characteristic that is under androgenic stimulation from the testis in the final stages of sexual maturation (Turner, 1941), and gonopodia are essential for sperm transfer (Batty and Lim, 1999). Gonopodial lengths and other secondary sex characteristics have been shown to be slightly inhibited by exposure to estrogenic chemicals like E2 at $100 \mathrm{ng} / \mathrm{L}$ (Doyle and Lim, 2002) and 4-nonylphenol (Dreze and others, 2000). Gonpodial elongation in mosquitofish has been an endpoint for endocrine impacts in mosquitofish exposed to sewage-contaminated water in Australia, whereby shorter gonopodia were associated with the presence of 
estrogenic chemicals (Batty and Lim, 1999). These results in 2004 showed that GI values were generally higher in Rialto Drain and Thousand Palms (fig. 12), indicating male fish from other SAR sites may have been exposed to estrogenic EDCs that resulted in impaired gonopodial development. Because male mosquitofish can only inseminate females when gonopodia are fully developed (Bisazza and others, 1996), impairment may affect reproduction (Batty and Lim, 1999). However, such effects were not as apparent in 2005 (fig. 13).

\section{Gonopodial Development}

In addition to gonopodial length, other morphologic characteristics are secondary sex characteristics essential for successful reproduction. Hooks and internal serrae serve as holdfasts for gripping a female during mating; therefore, their presence is considered a sign of sexual maturity (Angus and others, 2001). Impaired development of hooks and serrae following exposure to estrogenic EDCs can affect reproduction (Doyle and Lim, 2002). Representative images of male gonopodia from western mosquitofish in this study report are presented (figs. 14-19) and can be associated to hook scoring.

In a nonparametric, one-way ANOVA for 2004 ( $P=$ $0.0998)$ and $2005(P=0.2599)$, the ray elongation ratios (R4:R6) were not significantly different among sites, nor did nonparametric Kruskal-Wallis tests show significant differences. Similarly, by using the Wilcoxon 2-sample test, ray elongation ratios were not noted as different among sites; however, by using ANOVA for $2004(P=0.0342)$ (fig. 20) and for 2005 ( $P=0.0088)$ (fig. 21), the ratios of the thickening of the sixth segment between rays three and four (R4S6:R3S6) (figs. 22 - 23) did show significant differences among sites:

2004: Thousand Palms $>$ TTWE $=$ Prado Dam (below) $>$

Rialto Drain $=$ Sunnyslope Creek

2005: Thousand Palms > Sunnyslope Creek > Prado Dam (within)

Similarly, by using the Kruskal-Wallis test, sites were significantly different in $2004(\mathrm{P}=0.0389)$ and $2005(\mathrm{P}=$ $0.0137)$.

The gonopodium, once developed, requires no further androgenic stimulation to maintain its structure (Angus and others, 2002). Thus, if environmental estrogens were to affect male gonopodial characteristics, it would presumably be by inhibition of gonopodium growth and development during sexual maturation (Doyle and Lim, 2002). New bone is added to ray 3 while the gonopodium is developing when testes are first producing androgens at the time of sexual maturation (Angus and others, 2001); hence, its measure compared to another ray provides a measure of thickening (Angus and others, 2002). In this study, ray-width ratios, a measure of a secondary sex characteristic under androgenic control, were significantly higher in each year at the reference site, Thousand Palms, not impacted by WWTP effluents. With regard to $\mathrm{T}$ levels, fish from this site showed the highest levels of T (along with Prado Dam in 2005, even with $n=2$ for R3S6:R4S6). Taken together, these data indicate that testosterone levels at WWTP-impacted sites had been lowered at the juvenile (by virtue of the R3S6:R4S6 data) and adult life stages (by virtue of the sex steroid hormone data) of western mosquitofish. Although the degree of gonopodial lengthening measured by the GI indicated some differences in gonopodial lengths among sites (fig. 12), and the ray 4 to ray 6 elongation ratios did not indicate differences among sites, the measures of widths of segment 6 of rays 3 and 4 showed effects (figs. 20-21). Another measure of the degree of gonopodial maturation is the presence or absence of hooks on the distal portion of rays 4 and 5 (Doyle and Lim, 2002).

This study is the first to score and statistically analyze gonopodial hooks and serrae, which serve as holdfast devices during copulation. For investigating potential differences among sites by using hook scores, categorical analysis was applied to the categorized scores of gonopodial hooks and serrae (table 6). For 2004 and 2005, there were significant associations with hook score $\left(\chi_{(4)}^{2}=18.152, P=0.001\right.$ for 2004; $\chi_{(1)}^{2}=7.636, P=0.006$ for 2005), and significant site differences (PROC CATMOD) were detected ( $P=0.0043$ for 2004; $P=0.0285$ for 2005) by using the no-intercept model.

In 2004, male mosquitofish from Thousand Palms and the TTWE point source showed the highest percentages of high hook scores, and the TTWE source was the only site to display equivalent $\mathrm{T}$ levels between males and females. A consequence was that differences in $\mathrm{E} 2 / \mathrm{T}$ ratios between male and female adults from that site were similar (fig. 11C). This hormonal mixture may have been prevalent during sexual maturation, thereby influencing hook development. Male fish from Thousand Palms displayed high T levels in 2004 and 2005 , and this was reflected by the high percentage of high hook scores.

Table 6. Number and percentage of categorized scores (where low is one to two and high is three to four) of gonopodial hooks and serrae from western mosquitofish (Gambusia affinis) in 2004 and 2005.

\begin{tabular}{lrrrr}
\hline & \multicolumn{2}{c}{ Percent Low } & Percent High \\
\hline \multicolumn{1}{c}{ Site (2004) } & N & & N & \\
$\quad$ & 13 & 87 & 2 & 13 \\
Sunnyslope Creek & 6 & 60 & 4 & 40 \\
Rialto Drain & 3 & 25 & 9 & 75 \\
TTWE & 13 & 68 & 6 & 32 \\
Prado Dam & 5 & 25 & 15 & 75 \\
Thousand Palms & 5 & & & \\
$\quad$ Site (2005) & 6 & 100 & 0 & 0 \\
Sunnyslope Creek & 2 & 100 & 0 & 0 \\
Prado Dam & 8 & 36 & 14 & 64 \\
Thousand Palms & &
\end{tabular}

${ }^{a}$ In 2004, the Prado Dam sampling site was below the dam (fig. 5), and in 2005 it was above Prado Dam in the Prado wetlands (fig. 6). 


\section{Organosomatic Indices}

\section{Gonadosomatic Index}

By one-way ANOVA, sites were significantly different in GSI for 2004 and 2005 at $P=0.0002$ and $P<0.0001$, respectively. Groupings by Duncan's multiple range test are displayed on graphs (fig. 24).

Organosomatic indices (ratios of organ weight to body weight), used in a number of stress assessment studies, can vary naturally with food availability, state of sexual maturation, and life history stage, often in concert with season (Barton and others, 2002). The assumption is that lower than normal GSI and HSI values indicate a diversion of energy away from organ or tissue growth in order to combat a stressor. Inadequate nutrition can have as great an effect on GSI, egg production (fecundity), and basal metabolism as can exposure to xenobiotics (Patyna and others, 1999). In this study, mean GSI values in male western mosquitofish at Rialto Drain in 2004 was 2.2 times higher than for males at Thousand Palms. Likewise in 2005, GSI values from western mosquitofish at the reference site were 2.7 and 2.6 times lower than those at Sunnyslope Creek and Prado Dam, respectively. Although higher GSI at impacted sites is contrary to evidence from some studies indicating fish exposed to xenobiotics have lower GSI values (Kime, 1998; Lavado and others, 2004), these results are similar to those reported in Lake Apopka, Fla., where testes of mosquitofish (G. holbrooki) from a reference site (Lake Woodruff, Fla,) were significantly smaller than those from fish at the contaminated site (Toft and others, 2003). In this study, the lower GSI values at the reference site, Thousand Palms, may be due to lower nutrient concentrations in this desert spring resulting in lower productivity and food availability compared to the sites along the SAR, where large amounts of WWTP effluents and urban runoff contribute organics to water flow.

\section{Hepatosomatic Index (HSI)}

In this study, sites were significantly different in HSI values (one-way ANOVA) for 2004 and 2005 at $P<0.0001$ and $P=0.0257$, respectively. Groupings by Duncan's multiple range test are displayed on graphs (fig. 25).

The HSI is the most frequently used organ-to-mass ratio (Goede and Barton, 1990). The liver serves as a major storage site for glycogen; therefore, HSI can provide an indication of the nutritional state of the fish. Some HSI values have been shown to decrease in fish stressed by adverse changes in water quality (Lee and others, 1983) and altered water flows (Barnes and others, 1984). The HSI can increase after exposure to certain types of contaminants, particularly petroleum hydrocarbons (Baumann and others, 1991). Livers of male mosquitofish (G. holbrooki) from Lake Apopka, Fla., a site with EDCs and other contaminants, were found to be heavier than those from nearby reference lakes (Toft and others, 2003). Amplified liver mass is presumably due to an increase in liver cell number (hyperplasia) and size (hypertrophy), as a consequence of the induction of the mixed-functionoxidase system to detoxify (for example, EROD activity) the contaminants (Poels and others, 1980). Spawning condition, however, can influence liver weight by virtue of vitellogenin production (Myers and Fournie, 2002). Because the liver is the major detoxification organ (Kime, 1998), altered liver morphology and enzymatic activity in fish is common following exposure to toxicants.

In this study in 2004, male mosquitofish with the highest HSI values were from Rialto Drain, Sunnyslope Creek, and Prado Dam - all sites with readily available nutrients, unlike Thousand Palms (fig. 25A). Fish from Thousand Palms and the TTWE point source showed the lowest HSI levels. Likewise, in 2005, the lowest HSI values were shown at Thousand Palms and Sunnyslope Creek (fig. 25B).

\section{Sperm Quality}

Xenobiotic pollutants, including EDCs, may disrupt reproductive endocrine function by interacting with the hypothalamus-pituitary-gonadal axis, as well as between the endocrine and immune systems (Arcand-Hoy and Benson, 1998). Pollutants can affect sperm (and egg) development indirectly by disturbance of the correct hormonal environment, but if such pollutants have hormonal activity themselves, they can also directly affect the local hormonal environment in which the gamete develops (Kime and Nash, 1999). Some pollutants can be toxic to the gamete itself. Sperm quality is the measure of the ability of sperm to successfully fertilize an egg (Rurangwa and others, 2004). The quality of sperm is a major contributing factor to successful production of fish larvae (Kime, 1998); quality, as well as the quantity, of sperm can be affected by endocrine disruption (Kime and Nash, 1999). Outside of the study of captive male broodstock, few thorough studies have been performed to address sperm quality in natural fish or mammalian populations (Malo and others, 2005).

The combination of multiple assays on sperm is a better predictor of male fertility than any individual test (Jenkins, 2000). Several sperm-quality assessments have been developed and verified for use with mosquitofish. These results, especially in combination with other biomarker and contaminants data, are reflective of male reproductive performance that may be impaired by exposure to EDCs from WWTP effluents and other xenobiotic pollutants. Impairment of sperm quality in western mosquitofish from the SAR reflects similar exposure and possible effects in the Santa Ana sucker. 

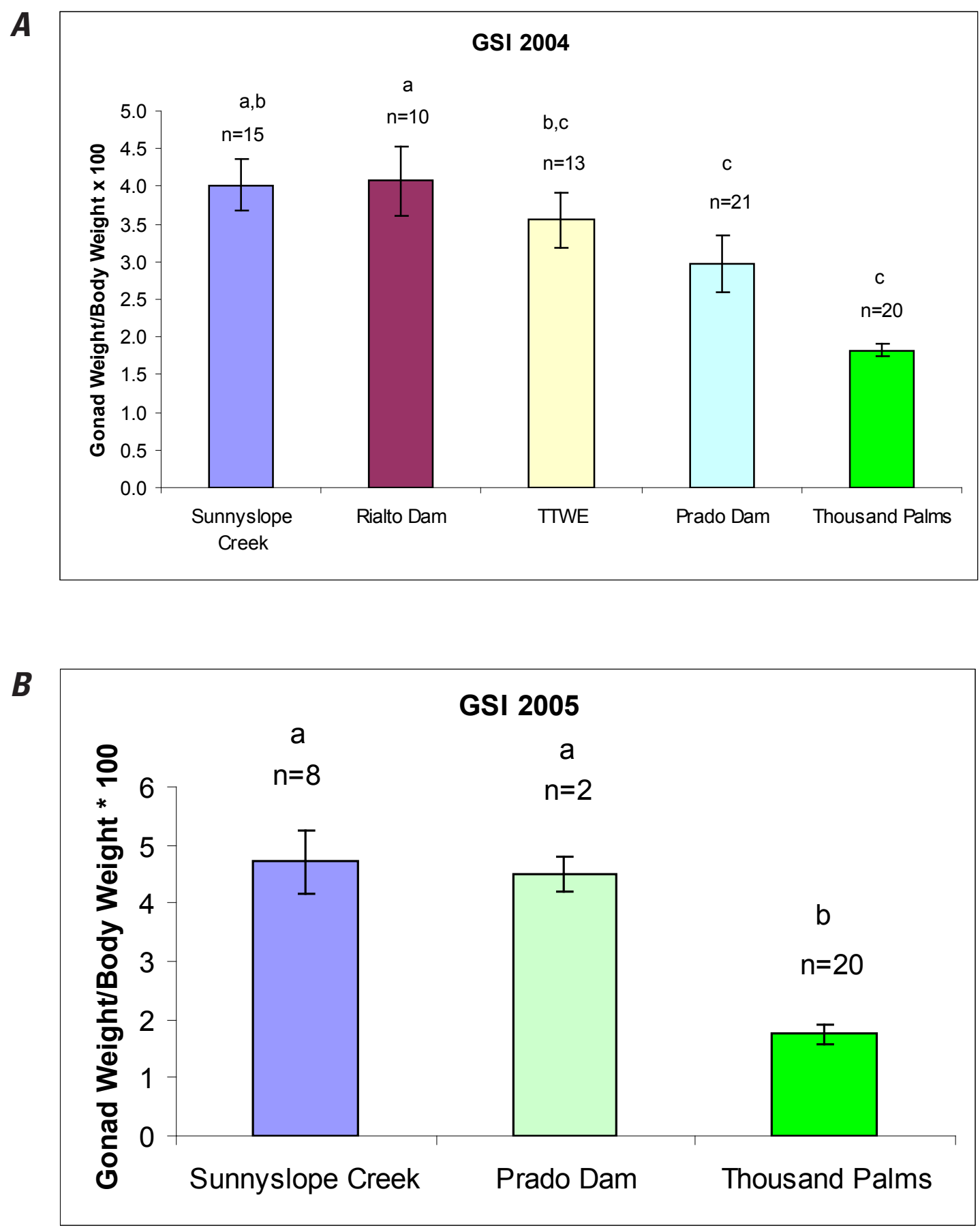

Figure 24. Gonadosomatic index values (GSI) (see standard error bars) from male western mosquitofish (Gambusia affinis) sampled from the Santa Ana River, Calif., in 2004 (A) and 2005 (B). Data were log transformed before analysis (one-way analysis of variance). Sample sizes (n) are provided per sampling location; samples close to tertiary treated wastewater effluent (TTWE) were collected at a point source. Site measurements were significantly different in $2004(P=0.0002)$ and $2005(P<0.0001)$, as indicated by different letters above bars. 

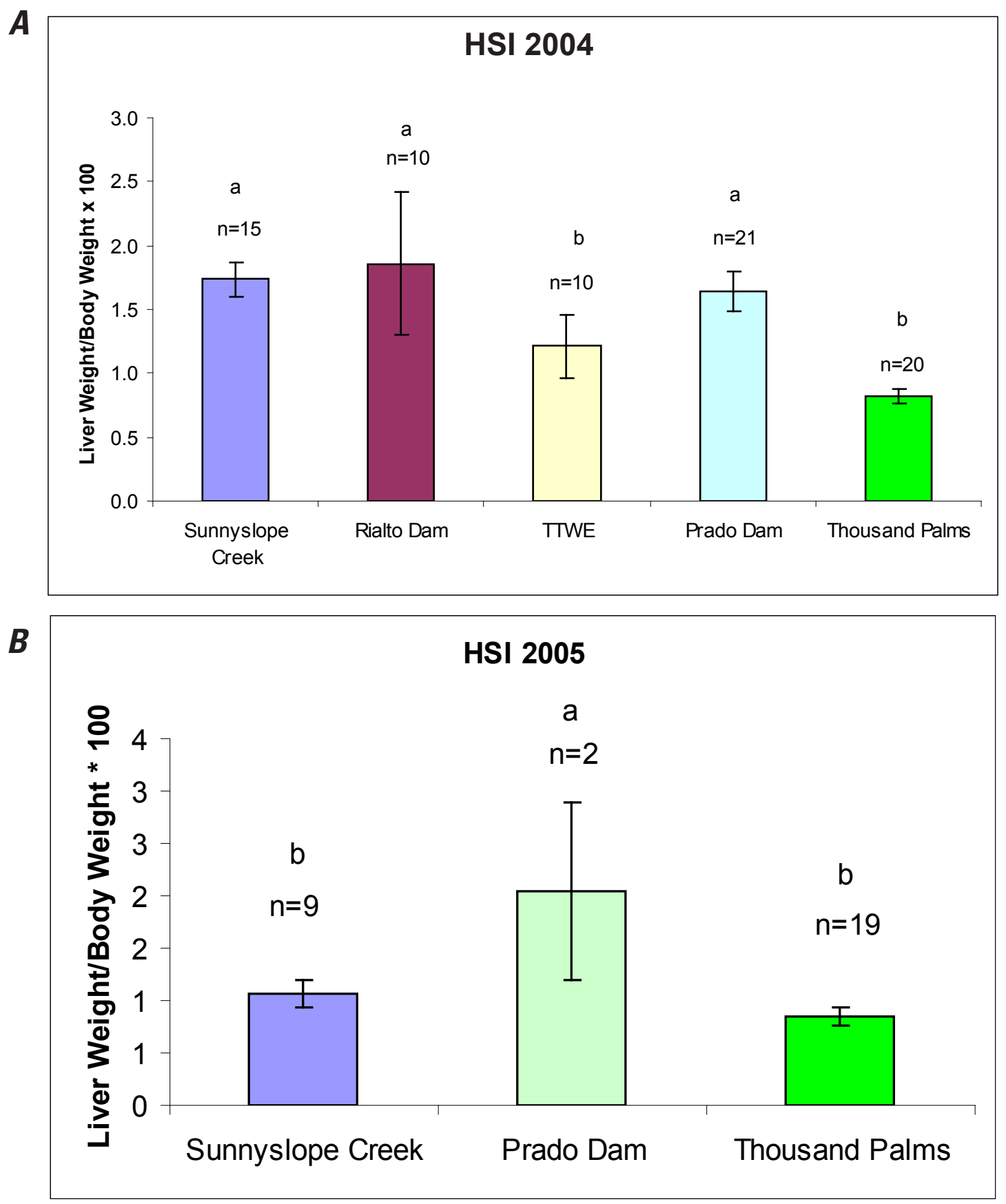

Figure 25. Hepatosomatic index (HSI) values (see standard error bars) from male western mosquitofish (Gambusia affinis) sampled from the Santa Ana River, Calif,, in $2004(A)$ and $2005(B)$. Sample sizes (n) are provided per sampling location; samples close to tertiary treated wastewater effluent (TTWE) were collected at a source point. Arcsine (square root), log transformed data analyzed by using one-way ANOVA, pairwise comparisons (least squares means) revealed differences among sites at $P<0.0001$ in 2004 and $P=0.0165$ in 2005. Different letters indicate significant differences among sites. 


\section{Motility}

The classic method of assessing the viability of sperm is to determine the percentage of progressively motile cells by using a microscope (Jenkins, 2000), and this has been used as an indirect method to measure metabolic activity. Percent motility and sperm velocity have been correlated to reproductive success in fish (Kime and others, 2001); many more studies have been done with direct application of compounds to cells rather than by systemic exposure. In one study of systemic exposure, examining the effect of environmentally relevant concentrations of E2 on gamete quality in rainbow trout (Onchorhynchus mykiss) and grayling (Thymallus thymallus), sperm motility patterns were altered in both, and sperm motility and swimming velocity were decreased in the grayling (Lahnsteiner and others, 2006). Additionally, milt volumes and sperm density were reduced in rainbow trout, and their fertility was impacted (Lahnsteiner and others, 2006).

Because of the evolutionarily conserved nature of the modes of action and developmental processes of sperm cells, multiple species comparisons are valid. Male fertility of natural populations of Iberian red deer (Cervus elephus hispanicus) has been clearly linked to sperm swimming velocity (Malo and others, 2005). Although the fertilization potential of male white suckers was not impacted by bleached kraft mill effluent in a Lake Superior bay, sperm motility was reduced (McMaster and others, 1992). Declines in hamster sperm velocity following oral exposure to 1,3-dinitrobenzene were linked to decreased fertility (Peiris and Moore, 2001). Motility of catfish and carp sperm was significantly decreased after direct exposure to tributyltin, an aromatase inhibitor (Rurangwa and others, 2002). Zebrafish exposed to environmentally realistic levels of tributyltin showed altered sperm motility, morphology, and milt volumes (McAllister and Kime, 2003). Zebrafish exposed to environmentally relevant concentrations of methyl-tert-butyl ether (MTBE), a chemical used as a gasoline additive, induced increased vitellogenin in males and lowered sperm motilities (Moreels and others, 2006). Fish spermatozoa, which are highly motile, will have a greater chance of fertilization (Rurangwa and others, 2004).

In this study, significant differences were found in sperm motilities among the sites for 2004 and 2005, at $P<0.0001$ and $P=0.0003$, respectively (fig. 26). Groupings by Duncan's multiple range test are noted graphically. The results of the t-tests for 2004 showed two significant results, whereby motilities from Thousand Palms were different from Prado $\operatorname{Dam}(P<0.0001)$ and from Sunnyslope Creek $(P=0.0001)$ but were not different from Rialto Drain or from the TTWE point source.

Therefore, sperm motilities were higher at the reference sites in both years than in the SAR sites, even though males from the reference sites had lower GSI levels in both years. The motility data indicate negative impacts on reproductive function of male western mosquitofish that are probably not due to basic water quality and nutrition, but are possibly due to exposure to xenobiotic pollutants and EDCs, some of which are listed in tables 2, 3, and 4 . The specific mechanisms within the endocrine system that resulted in lowered sperm motilities at the SAR sites are not fully understood, but lower $\mathrm{T}$ levels could be a significant factor.

\section{Viability and Mitochondrial Function}

Viability of fish sperm is often delineated by its progressive motility (Garner and others, 1997) and not truly measured. In one of the few studies on semen characteristics in a natural population, sperm viability was not associated directly with male fertility because cell viability is so essential for fertilization that males with lower values have been intensively selected against in natural populations (Malo and others, 2005). However, endocrine disruption by xenobiotics can result in decreased viability of gametes by cytotoxicity to the cells themselves or by disrupting the hormonal environment during gamete development (Kime and Nash, 1999). Gamete quality is also influenced by nutritional factors, as well as by temperature and dissolved oxygen (Schreck and others, 2001).

Although fertilization is the ultimate indicator of spermatozoal viability, fertility trials in field studies are impractical. Hence, the laboratory method of measuring intact cell membranes, most often used with eukaryotic cells, has been validated with mosquitofish sperm (Jenkins and Dale, 2006) used with fish and shellfish species (Segovia and others, 2000; Jenkins and Goodbred, 2005; Paniagua-Chavez and others, 2006; Goodbred and others, 2007; Tiersch and others, 2007; Horvath and others, in press) and has been used with avian and mammalian species for domestic reproduction. In this study, sperm viability was directly measured by virtue of an intact cytoplasmic membrane. Membrane disruption can occur when certain xenobiotics and lipids in membranes are peroxidized after toxic intermediates have been generated (Schlenk, 2001). Reactive oxygen molecular intermediates can result, and motility can be lowered. Antioxidants such as ascorbic acid (Dabrowski and Ciereszko, 2001) are important not only for maintaining intact membranes but also for maintaining the genetic integrity of sperm by preventing oxidative damage to DNA (Dabrowski and Ciereszko, 1996).

Lower sperm viability potentially could lower fertilizing ability if significant enough. One possible explanation for the lack of effects on sperm viability and mitochondrial function (see below) in male mosquitofish from SAR sites might be that mosquitofish chronically exposed to contaminants develop resistance to some of the effects of these compounds by developing various detoxification mechanisms (Chambers and Yarbrough, 1973).

The results of the viability analysis indicated there were no significant differences among the sites for 2004 ( $P=0.1057$ ), but for 2005, pairwise comparisons (least squares means) indicated a difference between values at Sunnyslope Creek and Thousand Palms $(P=0.0045)$ (fig. 27). The slightly lower viability at Thousand Palms was not 

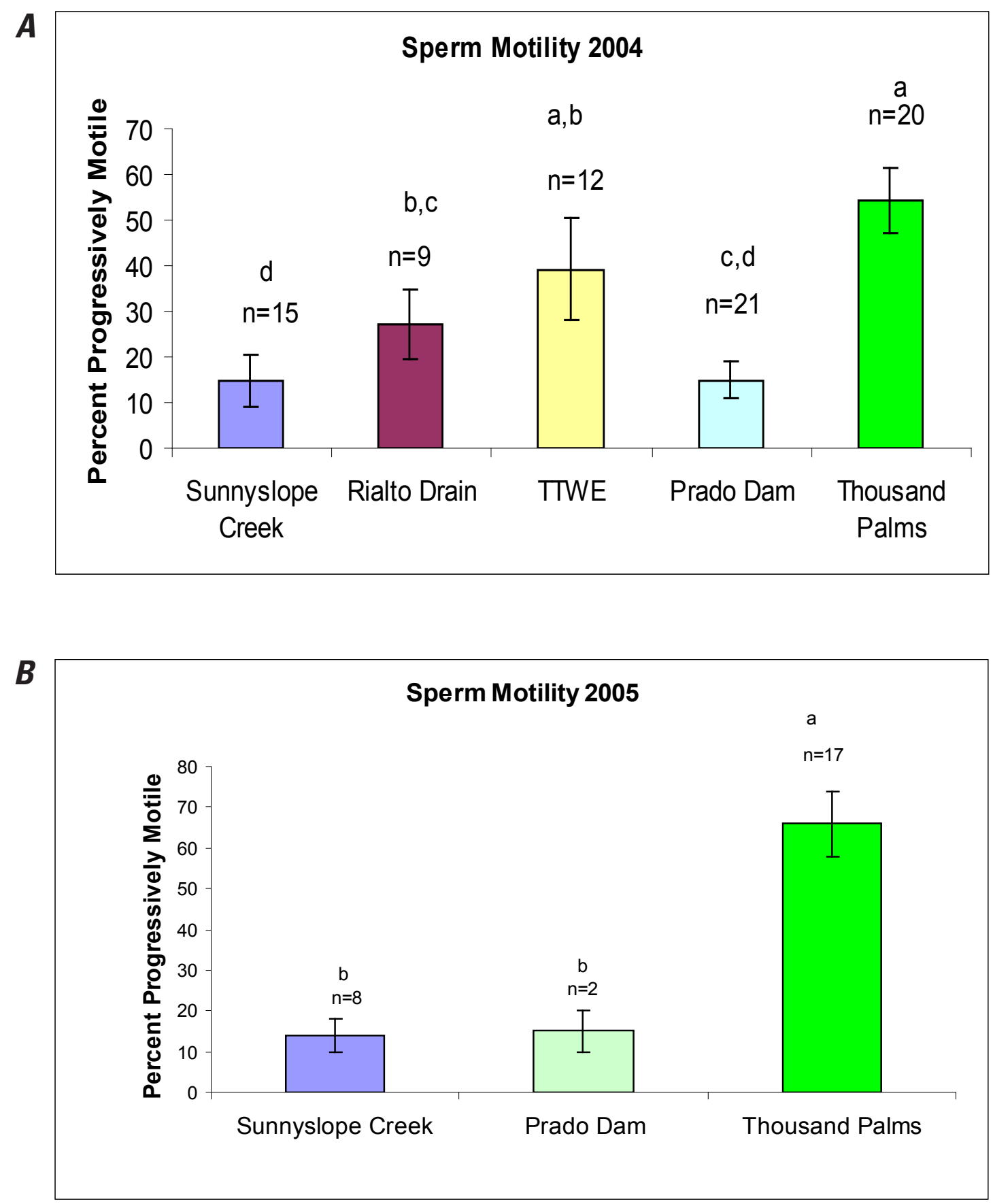

Figure 26. Visual assessments of progressively moving western mosquitofish (Gambusia affinis) spermatozoa from samples collected from the Santa Ana River, Calif., in $2004(A)$ and $2005(B)$. Assessments were made by using darkfield microscopy following activation of cells with water. Sample sizes ( $\mathrm{n}$ ) are provided per sampling location; samples close to tertiary treated wastewater effluent (TTWE) were collected at a point source. Arcsine (square root) transformations were applied to percent motility (see standard error bars), and site differences were noted (one-way analysis of variance followed by Duncan's multiple range test), where $P<0.0001$ for 2004, and $P=$ 0.0003 for 2005 , as noted by letters above the bars. 

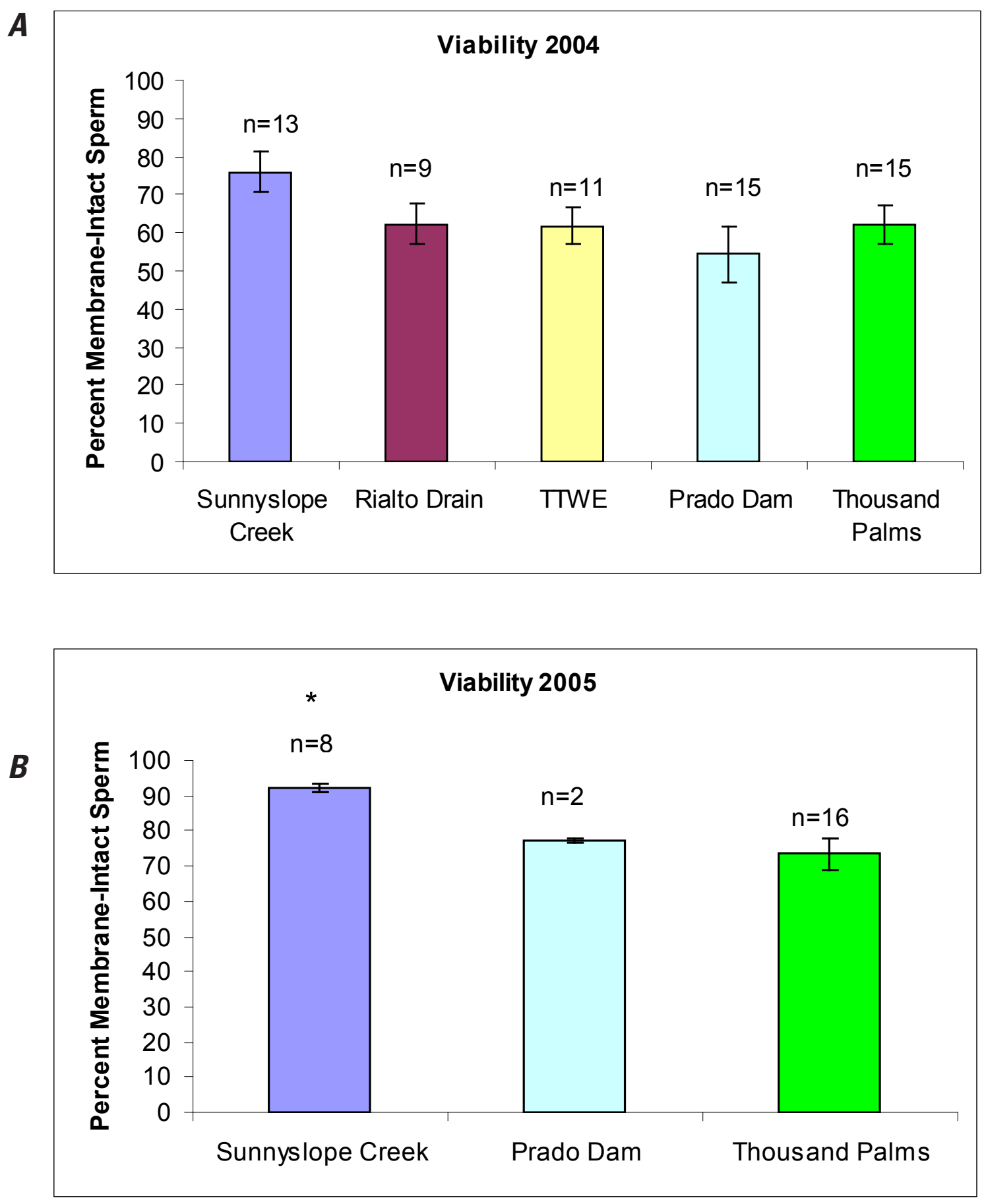

Figure 27. Percent of spermatozoa showing functional mitochondrial membrance function in western mosquitofish (Gambusia affinis) collected from the Santa Ana River, Calif., in $2004(A)$ and $2005(B)$. Results were determined by using dual fluorescent staining and flow cytometry. Sample sizes (n) are provided per sampling location; samples close to tertiary treated wastewater effluent (TTWE) were collected at a point source. Data were arcsine (square root) transformed; one-way analysis of variance and t-tests showed no significant differences among sites in 2004. In 2005, a significant difference in viability values were noted between Thousand Palms and Sunnyslope Creek (pairwise comparison via least squares means; $P=0.0045$ [see asterisk]). 
due to contaminants, but may have been due to the lower nutritionally related antioxidant effects.

In mammals, the mitochondrial membrane potential of sperm cells evaluated by flow cytometry has been used as markers of fertility potential (Troiano and others, 1998). Mitochondria fuel the sperm midpiece to generate energy to support motility, so differences in mitochondrial membrane potential are good indicators of functional impairment. Correlations have often been found in studies of domestic animals with mitochondrial function measures and sperm motility, but few studies have been done with field fish (Jenkins and Dale, 2006). Mitochondrial membrane potential is reduced (fig. 28) when energy metabolism is disrupted, often during the apoptotic process, leading to cell death (Shapiro, 2000).

Mitochondrial function was measured by virtue of its membrane maintaining a concentration gradient, whereby the cationic rhodamine 123 dye was accumulated in the functional mitochondria. Receptors for estrogen have been found on mitochondrial membranes in mammals, but until now no descriptions of effects of environmental pollutants through these pathways have been provided (Ropero and others, 2006).

\section{Sperm Counts}

The spermatogenic process, whereby spermatogonia develop into mature spermatozoa, is influenced by hormones. Sperm count is a fundamentally important predictor of male fertility. However, few studies have been done in aquatic species to examine whether estrogenic chemicals affect numbers of sperm produced. More studies have been done with rodent models, in particular. Sperm counts were dramatically reduced in guppies (Poecilia reticulata) following 21 days of exposure to low levels of tributyltin or bisphenol A (Haubruge and others, 2000). This reduction was likely due to impacts on Sertoli cells that sustain the spermatogenic process at every stage, including nutritive support and release of cells into ducts. These cells also express sex steroid receptors, and they respond to estrogens by stimulating the stem cell renewal divisions ( $2 \mathrm{~N}$ compartment; see Sperm Maturity section below) but not the spermatogonial proliferation, which leads to haploid sperm (Schulz and Miura, 2004). The number of Sertoli cells in mammalian adults is directly related to daily sperm production in mammals (Johnson and others, 2000), so estrogen exposures during male development could limit future sperm production (Staub and others, 2002).

The administration of high doses of E2 to male fish has led to regression of testicular tissue and sex reversal (Devlin and Nagahama, 2002). In a study of guppies that were fed the antiandrogenic fungicide vinclozolin and DDT metabolite $p, p$ '-DDE, secondary sex characteristics (including gonopodium development and color display) were reduced, as were sperm counts; however, the GSI was not impacted (Bayley and others, 2002). In a study of sexually mature male carp exposed to 4-tert-pentylphenol and E2 during spermatogenesis, spermatocrit values of those exposed to high levels of 4-tert-pentylphenol were lower than those of the controls, and those exposed to the highest concentration of ethinyl estradiol produced no milt in common carp, Cyprinus carpio (Gimeno and others, 1998).

In a study of mosquitofish at a contaminated site, sperm counts were significantly lower than at the reference site (Toft and others, 2003). These studies may provide insight into the biologic mechanisms occurring in western mosquitofish.

In the current study, in 2004, t-testing detected a significant difference in sperm counts between Thousand Palms and Prado Dam $(P=0.0404)$ and between Thousand Palms and Sunnyslope Creek $(P=0.0239)$ (fig. 29A). In 2005, no significant differences were noted (fig. 29B).

\section{Sperm Maturity}

During the spermatogenic process, or the formation of mature spermatozoa, three major phases occur where each stage is composed of cells of different ploidy or DNA complements. In the first stage, the cycling spermatogonium $(2 \mathrm{~N})$ proliferates mitotically to the spermatocyte $(4 \mathrm{~N})$. Spermatogonia are the male germ cells that continuously produce sperm cells for the next generation. Next, spermatocytes go through meiotic divisions to spermatids. Thirdly, spermatids go through spermiogenesis whereby the spermatids are restructured into flagellated spermatozoa (1N) (Schulz and Miura, 2004). Each of these cell populations is easily identifiable by virtue of DNA staining and flow cytometric analysis, and in cases of disordered spermatogenesis, the ploidy relationship will be disproportionate (Dey and others, 2000). More tightly compacted DNA is contained in nuclei just near the haploid complement; hence for this study, these two sperm populations were designated as the most mature cell populations. The results obtained can be analogous to spermatogenic staging performed by histology (Patino and others, 2003).

In this study, significant differences were noted in the levels of most mature sperm cell forms in $2004(P=0.0025)$ and $2005(P<0.0001)$ (fig. 30). Groupings by Duncan's multiple range test are noted on graphs. For both years of this study, mosquitofish at the reference site showed significantly higher percentages of mature sperm, indicating a higher reproductive capability. In one study of sexually mature male carp exposed to 4-tert-pentylphenol and E2 during spermatogenesis, histological sections showed the progressive disappearance of spermatozoa and spermatogenic cysts, along with pathological alterations such as vacuolation and atrophy of the germinal epithelia (Gimeno and others, 1998). The testicular level of $\mathrm{T}$ is important during spermatogenesis and spermiogenesis (formation of compact spermatids). Levels of $\mathrm{T}$ in males at impacted sites in this study may have influenced the formation of mature sperm of western mosquitofish. 

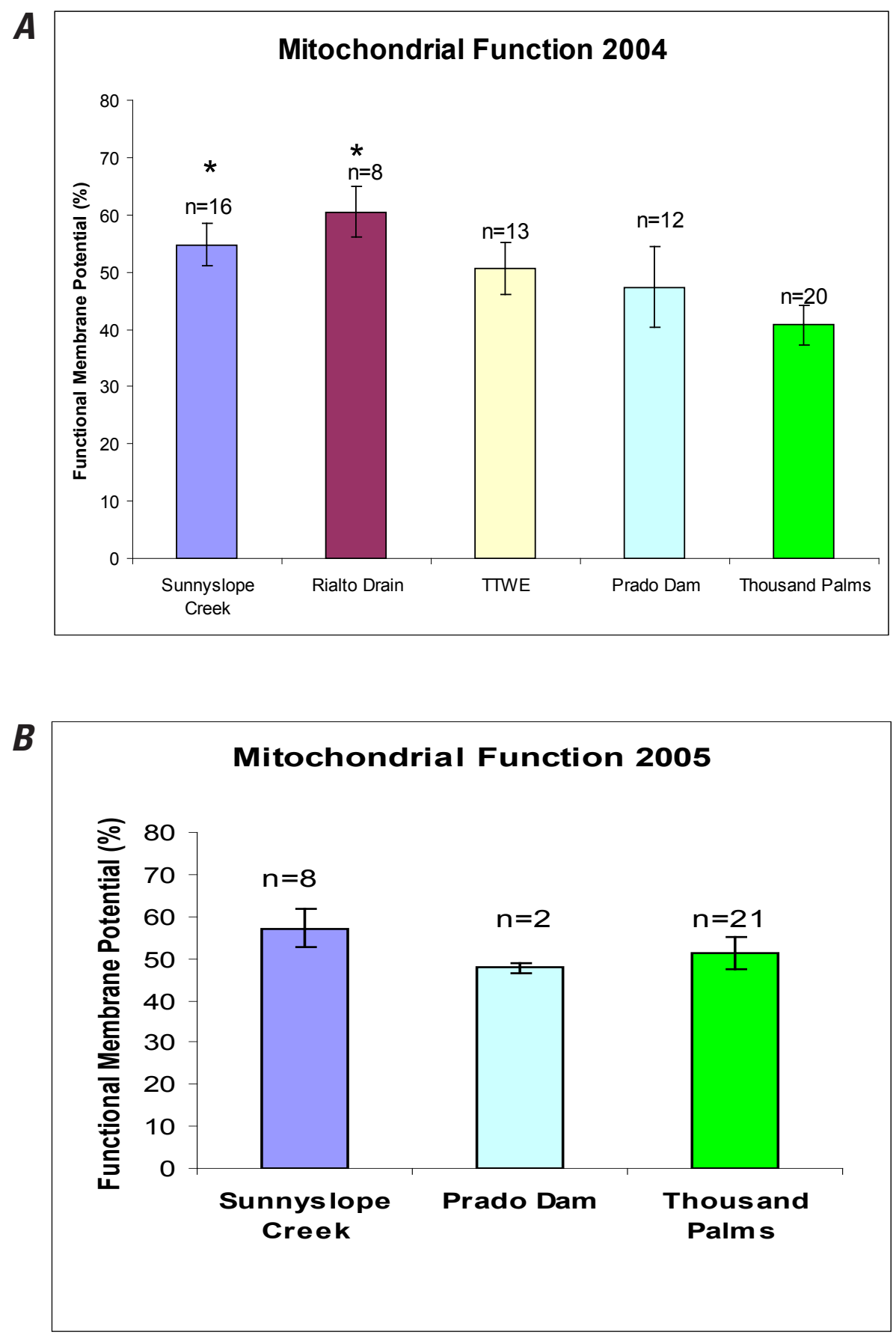

Figure 28. Percent of spermatozoa showing functional mitochondrial membrane function in western mosquitofish (Gambusia affinis) sampled from the Santa Ana River, Calif., in $2004(A)$ and $2005(B)$ (see standard error bars) in testis was determined by using dual fluorescent staining and flow cytometry. Sample sizes (n) are provided by sampling location; samples close to tertiary treated wastewater effluents (TTWE) were collected at a point source. By using t-tests comparing the reference site to each of the others, in 2004 there was a significant difference between values from Thousand Palms and Rialto Drain $(P=0.0040)$ and also between those from Thousand Palms and Sunnyslope Creek $(P=0.0105)$; see asterisks. 

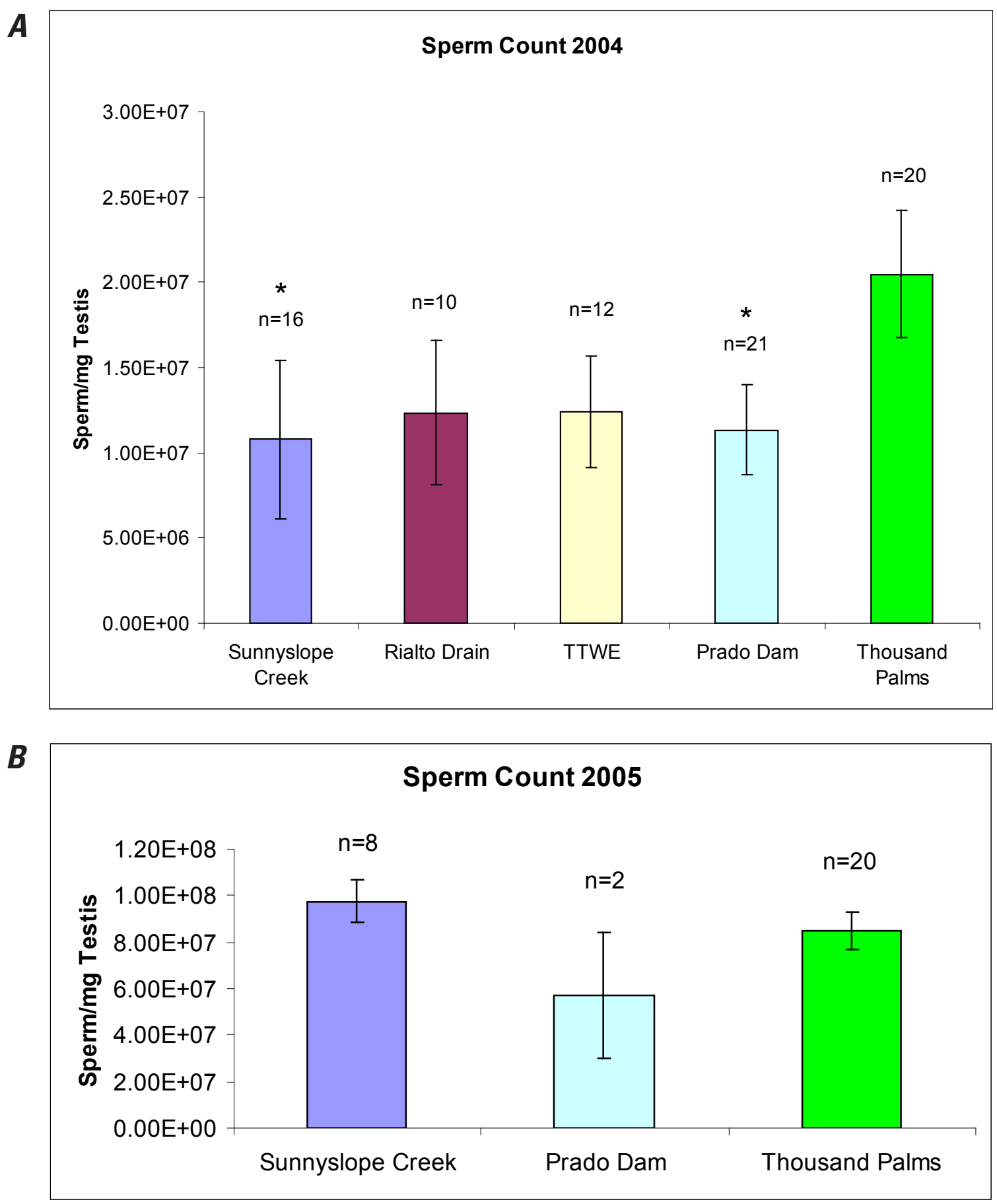

Figure 29. Sperm counts (see standard error bars) in western mosquitofish (Gambusia affinis) samples collected from the Santa Ana River, Calif., in $2004(A)$ and $2005(B)$. Counts were measured as number of cells per milligrams of testis. Sample sizes (n) are provided per sampling location; samples close to tertiary treated wastewater effluent (TTWE) were collected at a source point. Asterisks $(A)$ indicate sites with significantly different values (by using t-tests) from the reference site (Thousand Palms) with Prado Dam $P=0.0404$ and Sunnyslope Creek at $P=0.0239$. No significant differences between sites were noted for 2005 (B). 

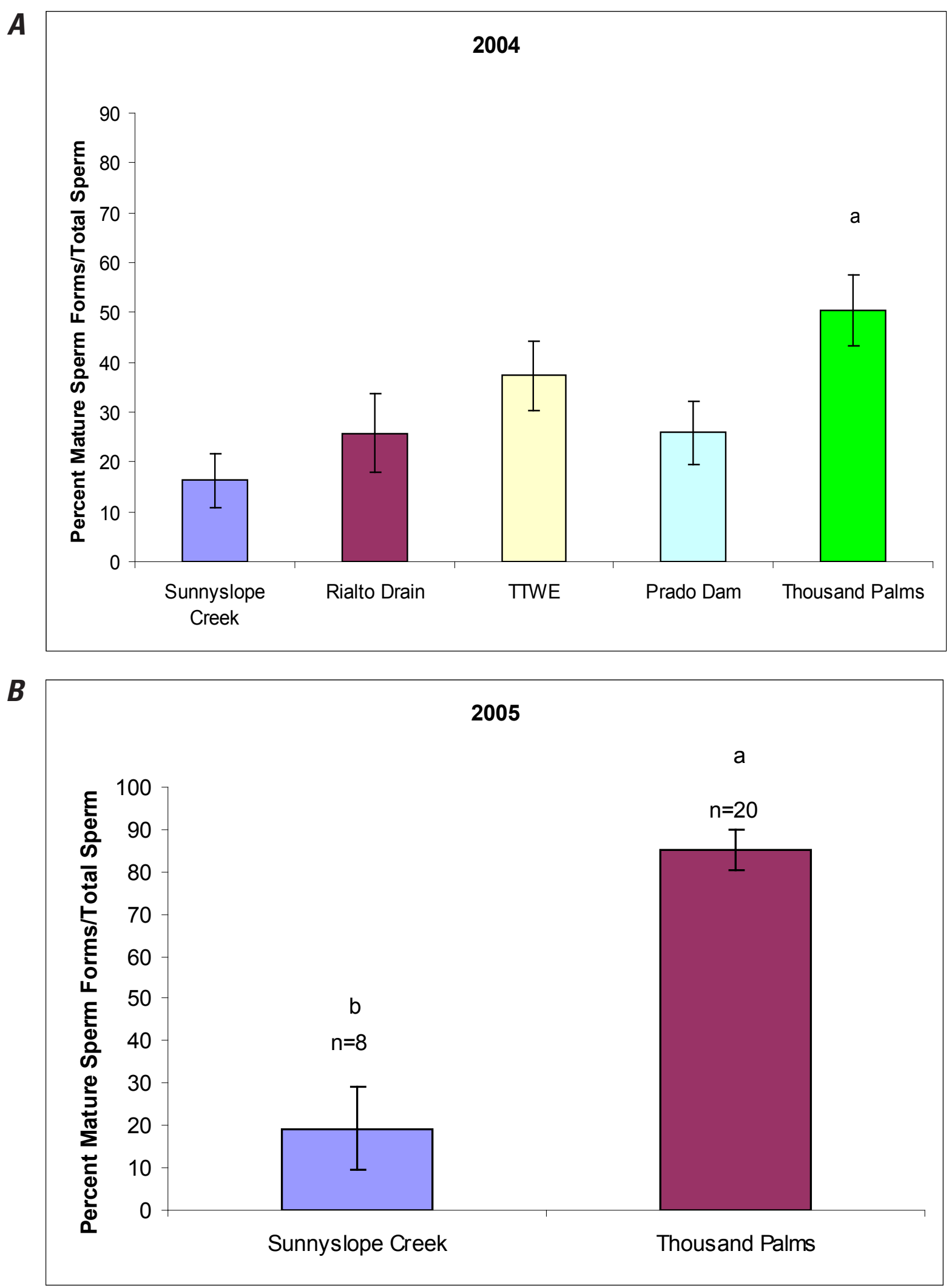

Figure 30. Percentage of mature sperm cell forms from western mosquitofish (Gambusia affinis) at Santa Ana River and reference sites in California in $2004(A)$ and $2005(B)$. Sample sizes $(n)$ are provided by sampling location; samples close to tertiary treated wastewater effluent (TTWE) were collected at a point source. Site differences (one-way analysis of variance and Duncan's multiple comparisons) were noted in $2004(P=0.0025)$ and $2005(P<0.0001)$, where significant differences are noted by letters above bars. 


\section{Correlation of Biomarkers with Contaminants}

Results of the Pearson product-moment correlation matrix produced mostly weak or nonsignificant correlations between biomarkers and contaminants. Some were also spurious because of the lack of detection of many contaminants or because there was not a large enough gradient in concentrations. Also, sample size was small because only mean biomarker values could be used, because there was only one contaminant sample taken at each site. Even with these constraints, this type of correlation matrix approach can help to elucidate potential relationships between exposures of environmental contaminants and consequent effects on endocrine and reproductive systems in aquatic biota. One correlation that was worthwhile exploring further was for phthalate esters. Phthalate esters, a group of industrial compounds widespread in the environment, are used in the production of plastics, and they have been considered to have some endocrine disrupting properties (Holm and others, 1995; Gray and others, 2000; Norman and others, 2007). Di (2-ethylhexyl) phthalate (DEHP) is produced and used in the highest quantity in the manufacture of polyvinyl chloride (PVC), which has been shown to cause intersex in fish (Norman and others, 2007) and to lower male reproduction in zebrafish (Holm and others, 1995). In mammals, androgen receptor antagonists inhibit testosterone production (Gray and others, 2000) that lowers sperm counts and maturation (Parmar and others, 1987). In this study, a strong negative correlation (Pearson's $r=-0.81, P=0.0371$ ) of DEHP from passive sample extracts from 2005 was found with $\mathrm{T}$ levels (fig.11E) in male western mosquitofish from 2004 (fig. 31).

Testicular injury by DEHP was reduced by the administration of $\mathrm{T}$ in rats (Parmar and others, 1987). Although the results in our study are supported by scientific literature, it is unknown how well DEHP levels in passive samplers reflect actual exposure of aquatic biota and which other antiandrogens are present in the SAR. Also, this correlation reflects mean $\mathrm{T}$ values from each site, not levels in individuals, and those data were collected in 2004, while the contaminants data were collected in 2005. Even so, additional investigations of DEHP as a possible compound of interest in environmental monitoring at SAR are warranted.

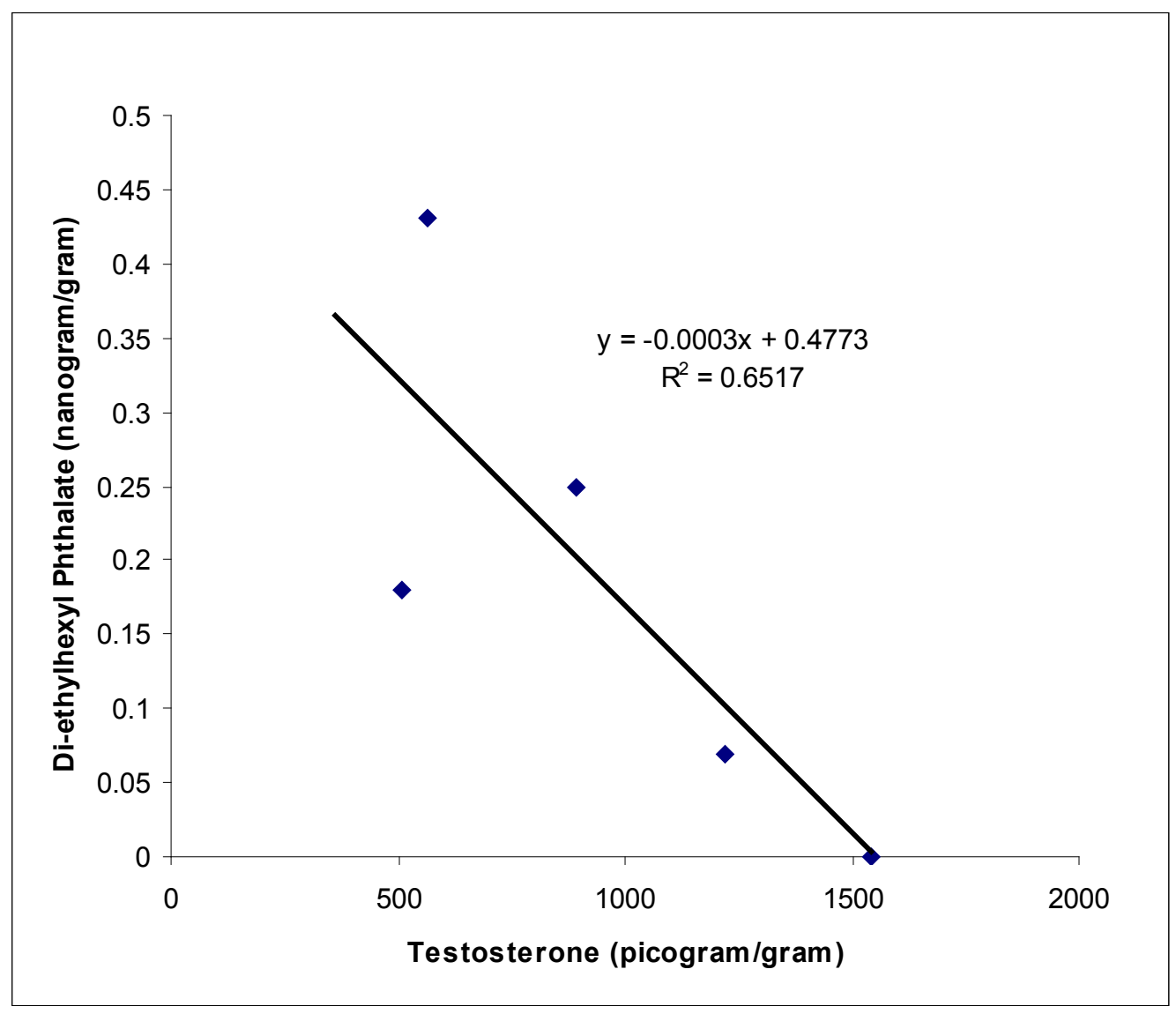

Figure 31. Correlation of testosterone (pigogram/g) in male western mosquitofish (Gambusia affinis) from Santa Ana River sites in California in 2004, with concentrations of di (2-ethylhexyl) phthalate (nanograms per gram) from extracts obtained by using polar organic chemical integrative samplers in 2005. 


\section{Summary and Conclusions}

The Santa Ana River (SAR) is impacted by effluents from wastewater treatment plants (WWTP), a source of organic wastewater compounds (OWCs) and urban runoff, each a potential source of endocrine disrupting compounds (EDCs). The SAR is one of only three river basins known to support native populations of the federally listed Santa Ana sucker (Catostomus santaanee) at the time the fish was listed in 2000. The objectives of this study were to determine if the threatened Santa Ana sucker was potentially exposed to OWCs and EDCs in the SAR by using the western mosquitofish (Gambusia affinis) as a surrogate. Evidence of exposure and bioaccumulation of EDCs was gathered by measuring environmental contaminants in aquatic biota during 2004 at four sites in the SAR basin and at one reference site. In 2005, exposure to OWCs and EDCs was further assessed at four SAR sites and one reference site by chemical analysis of passive sampler extracts from water. Endocrine disruption was characterized by analyzing sex steroid hormones, secondary sex characteristics, organosomatic indices, and sperm quality. To further assess which sites showed evidence of chemicals most able to impact sex steroid activity, a toxicity identification and evaluation process was performed on extracts from passive samplers. Eluted fractions from these samples were tested with yeast transgenic for an estrogen receptor, whereby fractions from water from the four SAR sites and a reference site were screened.

The OWCs and EDCs detected had a higher potential for impacting endocrine systems than the OCs, where the highest levels of estrogenicity were found below a WWTP. Twenty-five out of 59 OCs analyzed were detected in SAR composite biota samples and were generally at low levels $(<10 \mathrm{ng} / \mathrm{g})$, except for BDEs, the sum of which was as high as 740 ng/g (at Rialto Drain). Groups of OCs detected include chlordanes (insecticides), PCBs (industrial compounds), DDTs (insecticides), and BDEs (flame retardants). There were 18 out of 59 wastewater-related compounds detected in POCIS and 11 out of 59 chemicals found in SPMDs from four SAR sites, where concentrations tended to be along a gradient of proximity to WWTPs (for example, higher concentrations closer to a WWTP). These compounds included phthalates (plasticizers), alkylphenol ethoxylates (surfactants), polycyclic musks (fragrances), and tri-phosphates (flame retardants).

The response of reproductive and endocrine biomarkers in western mosquitofish at the SAR sites showed significant evidence of endocrine disruption compared to the reference site. At all WWTP-impacted SAR sites in 2004, the levels of $17 \beta$-estradiol (E2) in females were significantly lower compared to levels at the reference site. In males in 2004, significantly lower T levels were seen at all WWTP-impacted sites in 2004, and significantly higher E2 levels were shown at TTWE. Moreover, there were significant differences from the normal E2:T ratios among SAR sites, where female ratios were approaching male-like ratios at Rialto Drain and Prado
Dam, and male ratios were female-like at the point source for TTWE.

Several secondary sex characteristics in male western mosquitofish from SAR sites showed impairment compared to males from the reference site. In 2004, the gonopodial indices (GI), a measurement of anal fin elongation, was statistically lower at the TTWE point sources, Sunnyslope Creek, and Prado Dam as compared with the reference site in 2004, but differences were not noted for 2005. Another measure of elongation, the ratio of fin ray 4 to fin ray 6 , was also lower at SAR sites in 2004 but not statistically different. However, the ratio of the width of segment 6 of ray 3 to ray 4 , a measure of thickening of gonopodium during sexual development, showed significantly lower ratios at SAR sites for both years compared to the reference site. Gonopodial hooks and serrae, which serve as holdfast devices during copulation, were significantly lower at all SAR sites for both years. Taken together, sex steroid hormones and secondary sexual characteristics indicated that androgen regulation of male gonopodial development was impaired at all SAR sites (Prado Dam, Sunnyslope Creek, TTWE, and Rialto Drain) compared to the reference site, Thousand Palms.

Other biomarkers in male western mosquitofish included organosomatic indices and sperm- quality parameters. Hepatosomatic indices were generally higher at SAR sites compared to the reference site for 2004 and 2005, indicating likely increased exposure to environmental contaminants. For both years, gonadosomatic indices were generally lower at the reference site, perhaps indicating lower food availability and nutrients. General sperm quality was impaired at each SAR site. Overall, sperm motilities, counts, and percent of mature cells were lower at SAR sites, although viability and mitochondrial function were generally not different. Taken together, impairment of sperm quality at SAR sites indicated reduced reproductive capability.

It appears that exposure and impairment followed a gradient of proximity to WWTP effluents, where the most significant effects were found at the TTWE point source and Rialto Drain, followed by Prado Dam and Sunnyslope Creek. Each of these sites is a potentially suitable habitat for the Santa Ana sucker, especially Sunnyslope Creek and Rialto Drain, where juvenile suckers have been observed. Many OWCs and EDCs were detected at each SAR site, and these likely contributed to the hormonal and reproductive impairment of western mosquitofish. However, one specific compound or group of compounds could not be singled out as causative. Di (2-ethylhexyl) phthalate (DEHP) was strongly negatively correlated with $\mathrm{T}$ in male mosquitofish. The site showing chemicals in water having the highest potential for influencing estrogenic function was below a WWTP at the point source for TTWE. One group of potent environmental estrogens that is likely contributing to impairment are the natural and synthetic estrogen hormones, especially ethinyl estradiol; however, these compounds were not investigated in this study. Multiple lines of evidence indicating impairment in reproductive and endocrine function in western mosquitofish 
from the SAR can be used as indicators identifying potential problems with threatened species like the Santa Ana sucker exposed to similar OWCs and EDCs.

\section{Acknowledgments}

Final Report USFWS 11430-4-H001 submitted to Sharon K. Taylor, Environmental Contaminants Division Chief, and Scott A. Sobiech, Deputy Field Supervisor, Carlsbad Fish and Wildlife Office, USFWS Region 1, Carlsbad, Calif.

The authors thank Scott Sobiech and Judy Gibson of the U.S. Fish and Wildlife Service, Carlsbad, Calif., Field Office; Tim Gross, Carla Wieser, and Travis Smith of the U.S. Geological Survey Florida Integrated Science Center; Darren Johnson of IAP World Services at the U.S. Geological Survey National Wetlands Research Center; Jack Waide, UMESC; Dennis Demcheck, USGS Louisiana Water Science Center; Reynaldo Patino, USGS Texas Cooperative Fish and Wildlife Research Unit; and Beth Vairin, Connie Herndon, Christina Boudreaux, and Bobbie Louthian, USGS Enterprise Publishing Network.

\section{References}

Alberto, A., Camargo, A.F.M., Verani, J.R., Costa, O.F.T., and Fernandes, M.N., 2005, Health variables and gill morphology in the tropical fish Astyanax fasciatus from a sewage-contaminated river: Ecotoxicology and Environmental Safety, v. 61, p. 247-255.

Alvarez, D.A., Petty, J.D., Huckins, J.N., Jones-Lepp, T.L., Getting, D.T., and Manahan, D.T., 2004, Development of a passive, in situ, integrative sampler for hydrophilic organic contaminants in aquatic environments: Environmental Toxicology and Chemistry, v. 23, p. 1640-1648.

Alvarez, D.A., Huckins, J.N., Petty, J.D., Jones-Lepp, T.L., Stuer-Lauridsen, F., Getting, D.T., Goddard, J.P., and Gravell, A., 2007a, Tool for monitoring hydrophilic contaminants in water: Polar Organic Chemical Integrative Sampler (POCIS), in Greenwood, R., Mills, G., and Vrana, B., eds., Passive Sampling Techniques: Comprehensive Analytical Chemistry, v. 48, p. 171-197.

Alvarez, D.A., Perkins, S.D., Goodbred, S.L., and Sobiech, S., 2007b, Toxicity identification and evaluation (TIE) approach to identifying estrogenic chemicals sequestered in passive samplers in the Santa Ana River Basin, California: Report to U.S. Fish and Wildlife Service, Carlsbad, CA., Dec 2007, 20 p.
Angus, R.A., McNatt, H.B., Howell, W.M., and Peoples, S.D., 2001, Gonopodium development in normal male and 11-ketotestosterone-treated female moquitofish (Gambusia affinis). A quantitative study using computer image analysis: General and Comparative Endocrinology, v. 123, p. 222234.

Angus, R.A., Weaver, S.A., Grizzle, J.M., and Watson, R.D., 2002, Reproductive characteristics of male mosquitofish (Gambusia affinis) inhabiting a small southeastern U.S. river receiving treated domestic sewage effluent: Environmental Toxicology and Chemistry, v. 21, p. 14041409 .

Arcand-Hoy, L.D., and Benson, W.H., 1998, Fish reproduction: An ecologically relevant indicator of endocrine disruption: Environmental Toxicology and Chemistry, v. 17, p. 49-57.

Barnes, M.A., Power, G., and Downer, R.G.H., 1984, Stressrelated changes in lake whitefish (Coregonus clupeaformis): Canadian Journal of Fisheries and Aquatic Sciences, v. 41, p. 141-150.

Barton, B.A., Morgan, J.D., and Vijayan, M.M., 2002, Physiological and Condition-Related Indicators of Environmental Stress in Fish, in Adams, S.M., ed., Biological Indicators of Aquatic Ecosystem Stress: Bethesda, MD, American Fisheries Society, p. 111-148.

Batty, J., and Lim, R., 1999, Morphological and reproductive characteristics of male mosquitofish (Gambusi affinis holbrooki) inhabiting sewage-contaminated waters in New South Wales, Australia: Archives of Environmental Contamination and Toxicology, v. 36, p. 301-307.

Baumann, P.C., Mac, M.J., Smith, S.B., and Harshbarger, J.C., 1991, Tumor frequencies in walleye (Stizostedion vitreum) and brown bullhead (Ictalurus nebulosus) and sediment contaminants in tributaries of the Laurentian Great Lakes: Canadian Journal of Fisheries and Aquatic Sciences, v. 48, p. $1804-1810$.

Bayley, M., Junge, M., and Baatrup, E., 2002, Exposure of juvenile guppies to three antiandrogens causes demasculinization and a reduced sperm count in adult males: Aquatic Toxicology, v. 56, p. 227-239.

Bernet, D., Schmidt-Posthaus, H., Wahli, T., and BurkhardtHolm, P., 2000, Effects of wastewater on fish health: An integrated approach to biomarker responses in brown trout (Salmo trutta L.): Journal of Aquatic Ecosystem Stress and Recovery, v. 8, p. 143-151. 
Bisazza, A., Pilastro, A., Palzaai, R., and Marin, G., 1996, Sexual behavior of immature male eastern mosquitofish: A way to measure intensity of intersexual selection: Journal of Fish Biology, v. 48, p. 726-737.

Bitsch, N., Dudas, C., Korner, W., Failing, K., Biselli, S., Rimkus, G., and Brunn, H., 2002, Estrogenic activity of musk fragrances detected by the E-screen assay using human MCF-7 cells: Archives of Environmental Contamination and Toxicology, v. 43, p. 257-264.

Bortone, S.A., and Davis, W.P., 1994, Fish intersexuality as indicator of environmental stress. Monitoring fish reproductive systems can serve to alert humans to potential harm: Bioscience, v. 44, p. 165-172.

Brown, L.R., Burton,C.A., and Belitz, K., 2005, Aquatic assemblages of the highly urbanized Santa Ana River Basin, California: American Fisheries Society Symposium, v. 47, p. 263-287.

Buerge, I.J., Buser, H. R., Muller, M.D., and Poiger, T., 2003, Behavior of the polycyclic musks HHCB and AHTN in lakes, two potential anthropogenic markers for domestic wastewater in surface waters: Environmental Science and Technology, v. 37, p. 5636-5644.

Burton, C.A., 2002, Effects of urbanization and long-term rainfall on the occurrence of organic compounds and trace elements in reservoir sediment cores, streambed sediment, and fish tissue from the Santa Ana River Basin, California: U.S. Geological Survey Water Resources Investigations Report 02-4175, Sacramento, CA. 73p.

Burton, C.A., Izbicik, J.A., and Paybins, K.S., 1998, Waterquality trends in the Santa Ana River at MWD Crossing and below Prado Dam, Riverside County, California: U.S. Geological Survey Water-Resources Investigations Report 97-4173, Sacramento, California. 36p.

Burton, C.A., Brown, L.R., and Belitz, K., 2005, Assessing water source and channel type as factors affecting benthic macroinvertebrates and periphyton assemblages in the highly urbanized Santa Ana Rivers Basin, California: American Fisheries Society Symposium, v. 47, p. 239-262.

Chambers, J.E., and Yarbrough, J.D., 1973, Organophosphate degradation by insecticide-resistant and susceptible population of mosquito-fish (Gambusia affinis): Pesticide Biochemistry and Physiology, v. 3, p. 312-316.

Chen, J., Ahn, K.C., Gee, N.A., Mohamed, M.I., Duleba, A.J., Zhao, L., Gee, S.J., Hammock, B.D., and Lasley, B.L., 2007, Triclocarban enhances testosterone action: A new type of endocrine disruptor?: Endocrinology, v. 1057, p. 1-15.
Conolly, R.B., and Lutz, W.K., 2004, Nonmonotonic doseresponse relationships: mechanistic basis, kinetic modeling, and implications for risk assessment: Toxicological Sciences, v. 77, p. 151-157.

Cooke, S.J., Bunt, C.M., Hamilton, S.J., Jennings, C.A., Pearson, M.P., Cooperman, M.S., and Markle, D.F., 2005, Threats, conservation strategies, and prognosis for suckers (Catostomidae) in North America: Insights from regional case studies of a diverse family of non-game fishes: Biological Conservation, v. 121, p. 317-331.

Crissman, H.A., and Steinkamp, J.A., 1973, Rapid simultaneous measurement of DNA, protein and cell volume in single cells from large mammalian cell populations: Journal of Cell Biology, v. 59, p. 766-771.

Dabrowski, K., and Ciereszko, A., 1996, Ascorbic acid protects against male infertility in a teleost fish: Cellular and Molecular Life Sciences, v. 52, p. 97-100.

Dabrowski, K., and Ciereszko, A., 2001, Ascorbic acid and reproduction in fish: Endocrine regulation and gamete quality: Aquaculture Research, v. 32, p. 623-638.

Daughton, C., and Ternes, T., 1999, Pharmaceuticals and personal care products in the environment: Agents of subtle change?: Environmental Health Perspective, v. 107, p. 907938 .

Devlin, R.H., and Nagahama, Y., 2002, Sex determination and sex differentiation in fish: An overview of genetic, physiological, and environmental influences: Aquaculture, v. 208, p. 191-364.

Dey, P., Mondal, A.K., Singh, S.K., and Vohra, H., 2000, Quantitation of spermatogenesis by DNA flow cytometry from fine-needle aspiration cytology material: Diagnostic Cytopathology, v. 23, p. 386-387.

Ding, W.H., Wu, J., Semendeni, M., and Reinhard, M., 1999, Occurrence and behavior of wastewater indicators in the Santa Ana River and the underlying aquifers: Chemosphere, v. 39, p. 1781-1794.

Doyle, C.J., and Lim, R.P., 2002, The effect of 17B-estradiol on the gonopodial development and sexual activity of Gambusia holbrooki: Environmental Toxicology and Chemistry, v. 21, p. 2719-2724.

Dreze, V., Monod, G., Cravedi, J.P., Biagianti-Rishbourg, S., and De Gac, F., 2000, Effects of 4-nonylphenol on sex differentiation and puberty in mosquitofish (Gambusia holbrooki): Ecotoxicology, v. 9, p. 93-103. 
Eriksson, P., Jakobsson, E., and Fredriksson, A., 2001, Brominated flame retardants: a novel class of developmental neurotoxicants in our environment?: Environmental Health Perspectives, v. 109, p. 903-908.

Feder, J.L., Smith, M.H., Chesser, R.K., Godt, M.J.W., and Asbury, K., 1984, Biochemical genetics of mosquitofish II. Demographic differentiation of populations in a thermally altered reservoir: Copeia, v. 1, p. 108-119.

Federal Register, 2000, Endangered and Threatened Wildlife and Plants; Threatened Status for the Santa Ana Sucker, Final Rule: Federal Register 65 (12 April 2000): p. 19686-19698, accessed December 11, 2007 at http://www.fws.gov/policy/library/00fr19686.pdf.

Federal Register, 2004, Endangered and Threatened Wildlife and Plants; Final Rule to Designate Critical Habitat for the Santa Ana Sucker (Catostomus santaanae): Federal Register 69 (26 February 2004): p. 8839-8861.

Garner, D.L., Thomas, C.A., Joerg, H.W., Dejarnette, J.M., and Marshall, C.E., 1997, Fluorometric assessments of mitochondrial function and viability in cryopreserved bovine spermatozoa: Biology of Reproduction, v. 57, p. 1401-1406.

Gimeno, S., Komen, H., Jobling, S., Sumpter, J., and Bowmer, T., 1998, Demasculinisation of sexually mature male common carp, Cyprinus carpio, exposed to 4-tertpentylphenol during spermatogenesis: Aquatic Toxicology, v. 43, p. 93-109.

Glenn, D.W., III, 1998, Effect of osmolality, extender and temperature on gamete storage of koi carp (Cyprinus carpio): Baton Rouge, LA., Louisiana State University, M.S. thesis, 202 p.

Goede, R.W., and Barton, B.A., 1990, Organismic indices and an autopsy-based assessment as indicators of health and condition in fish: in Adams, S.M., ed., Biological indicators of stress in fish: Bethesda, MD., American Fisheries Society, p. 93-108.

Goodbred, S.L., Leiker, T.J., Patino, R., Jenkins, J.A., Denslow, N.D, Orsak, E., and Rosen, M.R., 2007, Organic chemical concentration and reproductive biomarkers in common carp (Cyprinus carpio) collected from two areas in Lake Mead, Nevada, May 1999-May 2000: U.S. Geological Survey Data Series 286, Sacramento, CA., 18p. with app.

Goodbred, S.L., Gilliom, R.J., Gross, T.S., Denslow, N.P., Bryant, W.L., and Schoeb, T.R., 1997, Reconnaissance of 17B-estradiol, 11-ketotestosterone, vitellogenin and gonad histopathology in common carp of United States streams: Potential for contaminant-induced endocrine disruption: U.S. Geological Survey Open-File Report 96-627, Sacramento, CA., 47p.
Gray Jr, L.E., Ostby, J., Fur, J., Price, M., Rao

Veeromachoneni, D.N., and Parks, L., 2000, Perinatal exposure to phthalates DEHP, BBP, and DINP, but DEP, DMP, or DOTP, alters sexual differentiation of the male rat: Reproductive and Developmental Toxicology, v. 58, p. 350-365.

Gross, B., Montgomery, J., Naumann, A., and Reinhard, M., 2004, Occurrence and fate of pharmaceuticals and alkylphenol ethoxylate metabolites in an effluent-dominated river and wetland: Environmental Toxicology and Chemistry, v. 23, p. 2074-2083.

Haglund, T.R., Baskin, J.N., and Swift, C.C., 2001, Results of year 1 implementation of the Santa Ana sucker conservation program for the Santa Ana River: Final report to the Santa Ana Watershed Protection Authority, Riverside, CA, 66p.

Haubruge, E., Petit, F., and Gage, M.J.G., 2000, Reduced sperm counts in guppies (Poecilia reticulata) following exposure to low levels of tributylin and bisphenol A: Proceedings of the Royal Society of London Biology, v. 267, p. 2333-2337.

Hem, J.D., 1989, Study and interpretation of the chemical characteristics of natural water: U.S. Geological Survey Water-Supply Paper 2254, Washington, D.C., 263p.

Hemming, J.M., Waller, W.T., Chow, M.C., Denslow, N.D., and Venables, B., 2001, Assessment of the estrogenicity and toxicity of a domestic wastewater effluent flowing through a constructed wetland system using biomarkers in male fathead minnow (Pimephales promelas Rafinesque, 1820): Environmental Toxicology and Chemistry, v. 20, p. 22682275.

Herren, D. and Berset, J.D., 2000, Nitro musks, nitro musk amino metabolites and polycyclic musks in sewage sludge quantitative determination by HR GC-ion-trap-MS/MS and mass spectral characterization of the amino metabolites: Chemosphere, v. 40, p. 565-574.

Holm, G., Halden, T., and Norrgren, L., 1995, Reproductive effects of di (2-ethylhexyl) phthalate (DEHP) on zebrafish (Brachydanio rerio): Marine Environmental Research, v. 39, p. 357-358.

Horváth Á., Wayman, W.R., Dean, J.C., Urbányi, B., Tiersch, T.R., Mims, S.D., and Jenkins, J.A., in press, Viability and fertilizing capacity of cryopreserved sperm from three North American Acipenseriform species: a retrospective study: Journal of Applied Ichthology.

Huckins, J.N., Petty, J.D., and Booij, K., 2006, Monitors of Organic Chemicals in the Environment - Semipermeable Membrane Devices: New York, Springer, 223 pp. 
Ishibashi, H., Matsumura, N., Hirano, M., Matsuoka, M., Shiratsuchi, H., Ishibashi, Y., Takao, Y., and Arizono, K., 2004, Effects of triclosan on the early life stages and reproduction of medaka Oryzias latipes and induction of hepatic vitellogenin: Aquatic Toxicology, v. 67, p. 167-179.

Jenkins, J.A., 2000, Infectious disease and quality assurance considerations for the transfer of cryopreserved fish gametes, in Tiersch, T.R., and Mazik P.M., eds., Cryopreservation in Aquatic Species: Baton Rouge, LA., World Aquaculture Society, p. 343-363.

Jenkins, J.A., and Draugelis-Dale, R., 2006, Bioindicators from Mosquitofish (Gambusia affinis) Sampled from the Imperial Valley in Southern California: U.S. Geological Survey Open File Report 2006-1307, Lafayette, LA. http:// pubs.usgs.gov/of/2006/1307/.

Jenkins, J.A., and Goodbred, S.L., 2005, Viability of male gametes in common carp (Cyprinus carpio) along the Lower Colorado River from the Cibola National Wildlife Refuge (NWR), Havasu NWR, and Lake Mohave of Lake Mead National Recreation Area: U.S. Geological Survey Open File Report 2006-1007, p 25. http://www.nwrc.usgs. gov/wdb/pub/others/05-298.pdf.

Johnson, L., Varner, D.D., Roberts, M.E., Smith, T.L., Keillor, G.E., and Scrutchfield, W.L., 2000, Efficiency of spermatogenesis: a comparative approach: Animal Reproduction Science, v. 60, p. 471-480.

Kelce, W.R., Stone, C.R., Laws, S.C., Gray, L.E., Kemppainen, J.A., and Wilson, E.M., 1995, Persistent DDT metabolite $p, p$ '-DDE is a potent androgen receptor antagonist: Nature, v. 375, p. 581-585.

Kime, D.E., 1998, Endocrine Disruption in Fish: Norwell, MA., Kluwer Academic Publishers, 396 p.

Kime, D., and Nash, J.P., 1999, Gamete viability as an indicator of reproductive endocrine disruption in fish: Science of the Total Environment, v. 233, p. 123-129.

Kime, D.E., van Look, K.J.W., McAllister, B.G., Huyskens, G., Rurangwa, E., and Ollevier, F., 2001, Computer-assisted sperm analysis (CASA) as a tool for E. and monitoring sperm quality in fish: Comparative Biochemistry and Physiology Part C, v. 130, p. 425-433.

Kojima, H., Katsura, E., Takeuchi, S., Niiyama, K., and Kobayashi, 2004, Screening for estrogen and androgen receptor activities in 200 pesticides by in vitro reporter gene assays using Chinese hamster ovary cells: Environmental Health Perspectives, v. 112, p. 524-531.
Kolpin, D.W., Furlong, E.T., Meyer, M.T., Thurman, E.M., Zaugg, S.D., Barber, L.B., and Buxton, H.T., 2002, Pharmaceuticals, hormones, and other organic wastewater contaminants in U.S. streams, 1999-2000: A national reconnaissance: Environmental Science \& Technology, v. 36, p. 1202-1211.

Kosmala, A., Migeon, B., Flammarion, P., and Garric, J., 1998, Impact assessment of a wastewater treatment plant effluent using the fish biomarker ethoxyresorufin- $O$ deethylase: Field and on-site experiments: Ecotoxicology and Environmental Safety, v. 41, p. 19-28.

Krumholz, L.A., 1948, Reproduction in the western mosquitofish, Gambusia affinis affinis (Baird \& Girard), and its use in mosquito control: Ecological Monographs, v. 18, p. 1-43.

Lahnsteiner, F., Berger, B., Kletzl, M., and Weismann, T., 2006, Effect of 17ß-estradiol on gamete quality and maturation in two salmonid species: Aquatic Toxicology, v. 79, p. 124-131.

Lavado, R., Thibaut, R., Raldua, D., Martin, R., and Porte, C., 2004, First evidence of endocrine disruption in feral carp from the Ebro River: Toxicology and Applied Pharmacology, v. 196, p. 247-257.

Lee, D.S., and Burgess, G.H., 1980, Gambusia affinis (Baird and Girard), mosquitofish in Lee, D.S., Gilbert, C.R., Holcutt, C.H., Jenkins, R.E., McAllister, D.E., and Stauffer, J.R. Jr., Atlas of North American freshwater fishes: Raleigh, NC., North Carolina State Museum of Natural History, 538 p.

Lee, R.M., Gerking, S.B., and Jezierska, B., 1983, Electrolyte balance and energy mobilization in acid-stressed rainbow trout, (Salmo gairdneri), and their relation to reproductive success: Environmental Biology of Fish, v. 8, p. 115-123.

Legler, J., and Brouwer, A., 2003, Are brominated flame retardants endocrine disruptors?: Environmental International, v. 29, p. 879-885.

Leiker, T.J., Madsen, J.E., Deacon, J.R., and Foreman, W.T., 1996, Methods of analysis by the U.S. Geological Survey National Water Quality Laboratory - Determination of chlorinated pesticides in aquatic tissue by capillary-column gas chromatography with electron-capture detection: U.S. Geological Survey Open-File Report 94-710, Denver CO., $42 \mathrm{p}$. 
Leusch, F.D.L., Chapman, H.F., Kay, G.W., Gooneratne, S.R., and Tremblay, L.A., 2006, Anal fin morphology and gonadal histopathology in mosquitofish (Gambusia holbrooki) exposed to treated municipal sewage effluent: Archives of Environmental Contamination and Toxicology, v. 50, p. $562-574$.

Malo, A.F., Garde, J.J., Soler, A.J., Garcia, A.J., Gomendio, M., and Roldan, E.R.S., 2005, Male fertility in natural populations of red deer is determined by sperm velocity and the proportion of normal spermatozoa: Biology of Reproduction, v. 72, p. 882-829.

McAllister, B.G., and Kime, D.E., 2003, Early life exposure to environmental levels of the aromatase inhibitor tributyltin causes masculinisation and irreversible sperm damage in zebrafish (Danio rerio): Aquatic Toxicology, v. 65, p. 309316 .

McDonald, K.K., Gross, T.S., Denslow, N.D., and Blazer, V.C., 2000, Reproductive indicators, in Schmitt, C.J., and Dethloff, G.M., Biomonitoring of Environmental Status and Trends (BEST) Program: Selected methods for monitoring chemical contaminants and their effects in aquatic ecosystems: U.S. Geological Survey Technical Report 2000-0005, $31 \mathrm{p}$.

McMaster, M.E., Portt, C.B., Munkittrick, K.R., and Dixon, D.G., 1992, Milt characteristics, reproductive performance, and larval survival and development of white sucker exposed to bleached kraft mill effluent: Ecotoxicology and Environmental Safety, v. 23, p. 103-117.

Meffe, G.K., and Snelson, F.F., 1989, Ecology and evolution of livebearing fishes: Englewood Cliffs, NJ., Prentice Hall, $453 \mathrm{p}$.

Mills, L.J., and Chichester, C., 2005, Review of evidence: are endocrine-disrupting chemicals in the aquatic environment impacting fish populations?: Science of the Total Environment, v. 343, p. 1-34.

Moreels, D., van Cauwenberghe, K., Dabaere, B., Rurangwa, E., Vromant, N., Bastiaens, L., Diels, L., Springael, D., Merckx, R., and Ollevier, F., 2006, Long-term exposure to environmentally relevant doses of methyl-tert-butyl ether causes significant reproductive dysfunction in the zebrafish (Danio rerio): Environmental Toxicology and Chemistry, v. 25 , p. 2388-2393.

Moyle, P.B., 2002, Inland fishes of California: Berkley, CA., University of California Press, $502 \mathrm{p}$.

Myers, M.S., and Fournie, J.W., 2002, Histopathological biomarkers as integrators of anthropogenic and environmental stressors, in Adams, S.M., ed., Biological indicators of aquatic ecosystem stress: Bethesda, MD., American Fisheries Society, p. 221-288.
Nakada, N., Nyunoya, H., Nakamura, M., Hara, A., Iguchi, T., and Takada, H., 2004, Identification of estrogenic compounds in wastewater effluent: Environmental Toxicology and Chemistry, v. 23, p. 2807-2815.

Nakada, N., Tanishima, T., Shinohara, H., Kiri, K., and Takada, H., 2006, Pharmaceutical chemicals and endocrine disrupters in municipal wastewater in Tokyo and their removal during activated sludge treatment: Water Research, v. 40 , p. $3297-3303$.

Nichols, K.M., Miles-Richarsson, S.R., Snyder, E.M., and Giesy, J.P., 1999, Effects of exposure to municipal wastewater in situ on the reproductive physiology of the fathead minnow (Pimephales promelas): Environmental Toxicology and Chemistry, v. 18, p. 2001-2012.

Nishihara, T., Nishikawa, J., Kanayama, T., Dakeyama, F., Saito, K., Imagawa, M., Takatori, S., Kitagawa, Y., Hori, S., and Utsumi, H., 2000, Estrogenic activities of 517 chemicals by yeast two-hybrid assay: Journal of Health Sciences, v. 46, p. 282-298.

Noggle, J.J., 2005, Eastern mosquitofish as a bioindicator of pulp and paper mill effluents: Gainesville, FL., University of Florida, Ph.D dissertation, 277 p.

Norman, A., Borgeson, H., David, F., Tienpont, B., and Norrgren, L., 2007, Studies of uptake, elimination and late effects in Atlantic salmon (Salmo salar) dietary exposure to di (2-ethylhexyl phthalate (DEHP) during early life: Archives of Environmental Contamination and Toxicology, v. 52 , p. 235-242.

Orlando, E.F., Davis, W.P., Edwards, T.M., Sulkowski, D.F., Toft, G., and Guillette, L.J. Jr., 2003, Mosquitofish as sentinels of exposure to environmental androgens and estrogen: Queretaro, Mexico, Proceedings of the II International Symposium on Livebearing Fishes, p 31.

Osemwengie, L.I., and Gerstenberger, S.L., 2004, Levels of synthetic musk compounds in municipal wastewater for potential estimation of biota exposure in receiving waters: Journal of Environmental Monitoring, v. 6, p. 1-8.

Paniagua-Chavez, C.G., Jenkins, J.A, Segovia, M., and Tiersch, T.R., 2006, Assessment of gamete quality for the eastern oyster (Crassostrea virginica) by use of fluorescent dyes: Cryobiology, v. 53, p. 128-138.

Parmar, D., Srivastava, S.P., Sing, G.B., and Seth, P.K., 1987, Effects of testosterone on the testicular atrophy caused by di (2-ethylhexyl) phthalate: Toxicological Letters, v. 36, p. 297-308. 
Patino, R., Goodbred, S., Draugelis-Dale, R., Barry, C.E., Foott, J.S., Wainscott, M.R., Gross, T.S., and Covay, K.J., 2003, Morphometric and histopathological parameters of gonadal development in adult common carp from contaminated and reference sites in Lake Mead, Nevada: Journal of Aquatic Animal Health, v. 15, p. 55-68.

Patyna, P.J., Davi, R.A., Parkerton, T.F., Brown, R.P., and Cooper, K.R., 1999, A proposed multigeneration protocol for Japanese medaka (Oryzias latipes) to evaluate effects of endocrine disruptors: The Science of the Total Environment, v. 233 , p. $211-220$.

Peiris, L.D.C., and Moore, H.D.M., 2001, Evaluation of effects of 1,3-dinitrobenzene on sperm motility of hamster using computer assisted semen analysis (CASA): Asian Journal of Andrology, v. 3, p. 109-114.

Petrovic, M., Eljarrat, E., Lopez de Alda, M.J., and Barcelo, D., 2004, Endocrine disrupting compounds and other emerging contaminants in the environment: a survey on new monitoring strategies and occurrence data: Analytical and Bioanalytical Chemistry, v. 78, p. 549-562.

Petty, J.D., Huckins, J.N., Alvarez, D.A., Brumbaugh, W.G., Cranor, W.L., Lieker, T., Rostad, C., Furlong, E., and Rastall, A.C., 2004, A holistic approach for assessing the presence and potential impacts of waterborne environmental contaminants: Chemosphere, v. 54, p. 695-705.

Poels, C.L.M., van der Gaag, M.A., and van der Kerkhoff, J.F.J., 1980, An investigation into the longterm effects of Rhine water on rainbow trout: Water Research, v. 14, p. 1029-1035.

Poon, W.L., Hung, C.Y., and Randall, D.J., 2002, The effects of aquatic hypoxia on fish, in Proceedings of the Sixth International Symposium, January 22-26, 2001: Fish Physiology, Toxicology, and Water Quality, La Paz B.C.S. Mexico. R.V. Thurson, (Ed.), Athens, Georgia, Ecosystems Research Division, p. 31-49.

Rasmussen, D., and Blethrow, H., 1991, Toxic Substances Monitoring Program 1988-89: Sacramento, CA., State Water Resources Control Board 91-1QW, 104 p., w app.

Rasmussen, D., 1992, Toxic Substances Monitoring Program 1990 Data Report: Sacramento, CA., State Water Resources Control Board 92-1QW, 23 p., w app.

Reid, G.K., and Wood, R.D., 1976, Ecology of inland waters and estuaries: New York, NY., D. Van Nostrand Co, 485 p.

Reinhard, M., and Debroux, J., 2001, Organic contaminant behavior during wetland treatment and groundwater recharge: Fountain Valley, CA., SARWQH 1998-2000.
Ropero, A.B., Alonso-Magdalena, P., Ripoll, C., Fuentes, E., and Nadal, A., 2006, Rapid endocrine disruption: Environmental estrogen actions triggered outside the nucleus: Journal of Steroid Biochemistry and Molecular Biology, v. 102, p. 163-169.

Rurangwa, E., Biegniewska, A., Slominska, E., Skorkowski, E.F., and Ollevier, F., 2002, Effect of tributyltin on adenylate content and enzyme activities of teleost sperm: a biochemical approach to study the mechanisms of toxicant reduced spermatozoa motility: Comparative Biochemistry and Physiology, v. 131, p. 335-344.

Rurangwa, E., Kime, D.E., Ollevier, F., and Nash, J.P., 2004, The measurement of sperm motility and factors affecting sperm quality in cultured fish: Aquaculture, v. 234, p. 1-28.

Saiki, M.K., 2000, Water quality and other environmental variables associated with variations in population densities of the Santa Ana sucker: Unpubl report to Santa Ana Watershed Protection Association from U.S. Geological Survey, Western Fisheries Research Center, Dixon, CA. 117 p.

Saiki, M.K., Martin, B.A., Knowles, G.W., and Tennant, P.W., 2007, Life history and ecological characteristics of the Santa Ana sucker, Catostomus santaanae: California Fish and Game, v. 93, p. 87-101.

Santa Ana Watershed Project Authority, 2003, About the watershed: Santa Ana Watershed Project Authority, accessed December 11, 2007 at http://www.sawpa.org/about/ watershed.htm\#population.

SAS Institute, 2003, SAS/STAT User's Guide, Release 6.07: Care, NC., SAS.

Schlenk, D., 2001, General Mechanisms of Toxicity, in Schlenk, D., and Benson, W. H., eds., Target Organ Toxicity in Marine and Freshwater Teleosts: New York, Taylor and Francis, p. 1-25.

Schmidt, C.W., 2001, The lowdown on low-dose endocrine disruptors: Environmental Health Perspectives, v. 109, p. 420-421.

Schreck, C.B., Contreras-Sanchez, W., and Fitzpatrick, M.S., 2001, Effects of stress on fish reproduction, gamete quality, and progeny: Aquaculture, v. 197, p. 2-24.

Schreurs, R.H.M.M., Sonneveld, E., Jansen, J.H.J., Seinen, W., and van der Burg, B., 2005, Interaction of polycyclic musks and UV filters with the estrogen receptor (ER), androgen receptor (AR), and progesterone receptor (PR) in reporter gene bioassays: Toxicological Sciences, v. 83, p. 264-272. 
Schulz, R.W., and Miura, T., 2004, Spermatogenesis and its endocrine regulation: Fish Physiology and Biochemistry, v. 26, p. 43-56.

Segovia, M., Jenkins, J.A., Paniagua-Chavez, C., and Tiersch, T.R., 2000, Flow cytometric evaluation of antibiotic effects on viability and mitochondrial function of stored sperm of Nile tilapia: Theriogenology, v. 53, p. 1489-1499.

Seinen, W., Lemmen, J.G., Pieters, R.H.H., Verbruggen, E.M.J., and van der Burg, B., 1999, AHTN and HHCB show weak estrogenic - but no uterotrophic activity: Toxicology Letters, v. 111, p. 161-168.

Sepulveda, M.S., Johnson, W.E., Higman, J.C., Denslow, N.D., Schoeb, T.R., and Gross, T.S., 2002, An evaluation of biomarkers of reproductive function and potential contaminant effects in Florida largemouth bass (Micropterus salmoides floridanus) sampled from the St. Johns River: The Science of the Total Environment, v. 289, p. 133-144.

Shapiro, H.M., 2000, Membrane potential estimation by flow cytometry: Methods, v. 21, p. 271-279.

Snyder, S.A., Keith, T.L., Verbrugge, D.A., Snyder, E.M., Gross, T.S., Kannan, K., and Giesy, J.P., 1999, Analytical methods for detection of selected estrogenic compounds in aqueous mixtures: Environmental Science \& Technology, v. 33, p. 2814-2820.

Staub, C., Hardy, V.B., Chapin, R.E., Harris, M.W., and Johnson, L., 2002, The hidden effect of estrogenic/ antiandrogenic methoxychlor on spermatogenesis: Toxicology and Applied Pharmacology, v. 180, p. 129-135.

Sumpter, J.P., and Johnson, A.C., 2005, Lessons from endocrine disruption and their application to other issues concerning trace organics in the aquatic environment: Environmental Science and Technology, v. 39, p. 43214332.

Tiersch, T.R., Yang, H., Jenkins, J.A., and Dong, Q., 2007, Sperm cryopreservation in fish and shellfish, in Roldan, E.R.S., and Gomendio, M., eds., Spermatology (Society of Reproduction and Fertility supplement 65 ): Nottingham, U.K., Nottingham University Press, p. 493-508.
Toft, G, Edwards, T.M., Baatrup, E., and Guilette Jr, L. J., 2003, Disturbed sexual characteristics in male mosquitofish (Gambusia holbrooki) from a lake contaminanted with endocrine disruptors: Environmental Health Perspectives, v. 111, p. 695-701.

Troiano, L., Granata, A.R.M., Cossarizza, A., Kalashnikova, G., Bianchi, R., Pini, G., Tropea, F., Carani, C., and Franceschi, C., 1998, Mitochondrial membrane potential and DNA stainability in human sperm cells: a flow cytometry analysis with implications for male infertility: Experimental Cell Research, v. 241, p. 384-393.

Turner, C.L., 1941, Gonopodial characteristics produced in the anal fins of females of Gambusia affinis affinis by treatment with ethinyl testosterone: Biological Bulletin, v. 80, p. 371383.

U.S. Environmental Protection Agency, 1986, Ambient Water Quality Criteria for Dissolved Oxygen: Washington, DC., Protection Agency, Office of Water Regulations and Standards, Criteria and Standards Division, EPA 440/5-86003.

Vermeirssen, E.L.M., Körner, O., Schönenberger, R., Suter, M.J.F., and Burkhardt-Holm, P., 2005, Characterization of environmental estrogens in river water using a three pronged approach: active and passive water sampling and the analysis of accumulated estrogens in the bile of caged fish: Environmental Science and Technology, v. 39, p. 81918198.

Vos, J.G., Dybing, E., Greim, H.A., Ladefoged, O., Lambre, C., Tarazona, J.V., Brandt, I., and Vethaak, A.D., 2000, Health effects of endocrine-disrupting chemicals on wildlife with special reference to the European situation: Critical Reviews in Toxicology, v. 30, p. 71-133.

Winkler, P., 1979, Thermal preferences of Gambusia affinis affinis determined under field and laboratory conditions: Copiea, v. 1, p. 60-64.

Wu, R.S.S., Zhou, B.S., Randall, D.J., Woo, N.Y.S., and Lam, P.K.S., 2003, Aquatic hypoxia is an endocrine disruptor and impairs fish reproduction: Environmental Science and Technology, v. 37, p. 1137-1141.

Ying, G.G., Kookana, R.S., and Ru, Y.J., 2002, Occurrence and fate of hormone steroids in the environment: Environmental International, v. 28, p. 545-551. 


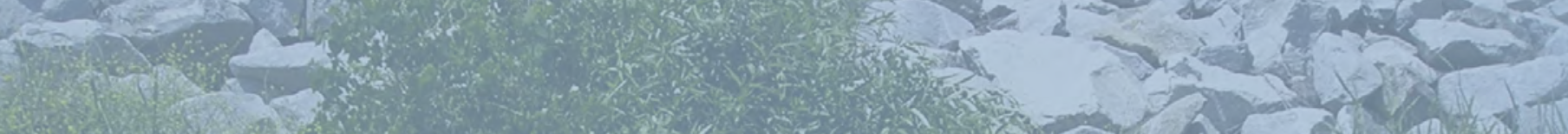

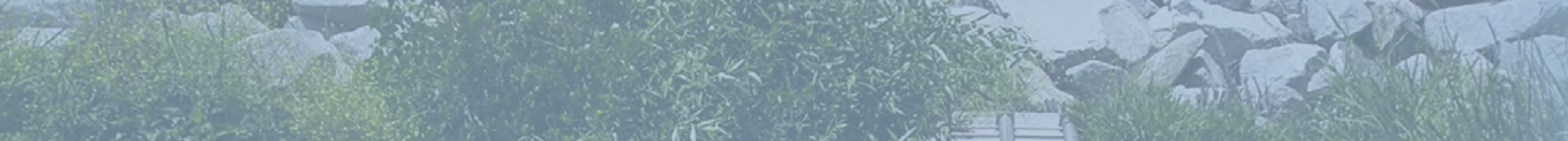

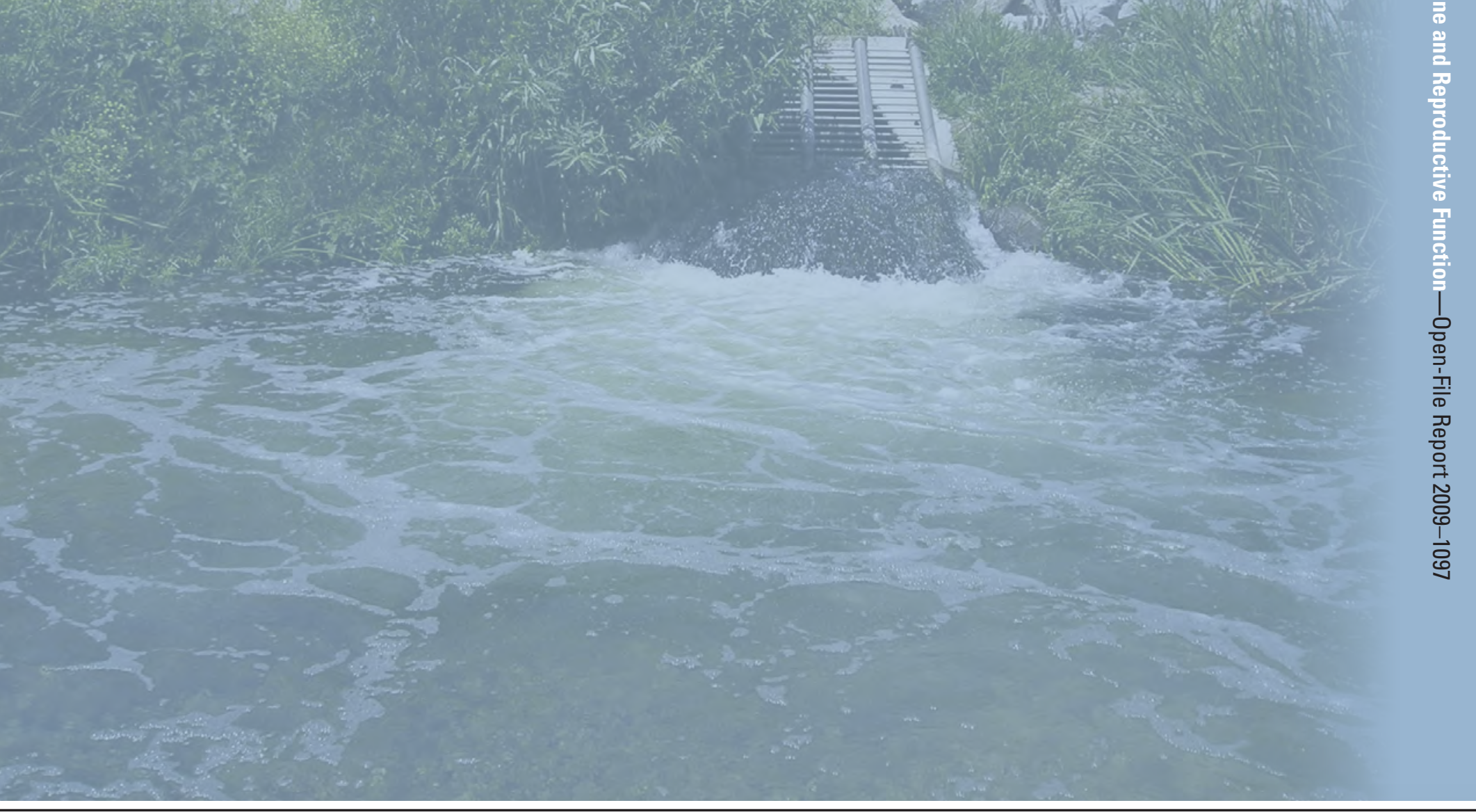

